\title{
Discovery of Selective, Orally Bioavailable Pyrazolopyridine Inhibitors of Protein Kinase C $\theta$ (PKC $\theta$ ) that Ameliorate Symptoms of Experimental Automimmune Encephalomyelitis
}

Philip N. Collier ${ }^{\dagger}$ Heather C. Twin, Ronald Knegtel, Dean Boyall, Guy Brenchley, Christopher J. Davis, Shazia Keily, Chau Mak, Andrew Miller, Françoise Pierard, Luca Settimo, Clare M. Bolton, Peter Chiu, Adam Curnock, Elisabeth Doyle, ${ }^{\dagger}$ Adam J. Tanner, Juan-Miguel Jimenez

Vertex Pharmaceuticals (Europe) Ltd., 86-88 Jubilee Avenue, Milton Park, Abingdon OX14 4RW, United Kingdom

†Vertex Pharmaceuticals Inc., 50 Northern Avenue, Boston, Massachusetts 02210, United States

\section{Contents of Supporting Information:}

$\begin{array}{ll}\text { 1. Chemistry and Synthetic Schemes } & \text { S2 }\end{array}$

2. Synthetic Procedures and Compound Characterization S12

3. Description of Biochemical Assays $\quad$ S34

$\begin{array}{ll}\text { a. PKC Inhibition assays } & \text { S34 }\end{array}$

b. Kinase selectivity assays $\quad$ S35

$\begin{array}{ll}\text { c. Kinase profiling (larger panel) } & \text { S37 }\end{array}$

$\begin{array}{ll}\text { 4. Description of Cellular Assays } & \text { S38 }\end{array}$

$\begin{array}{ll}\text { a. PBMC T Cell IL-2 assays } & \text { S38 }\end{array}$

b. HFL-1 Assay $\quad$ S38

$\begin{array}{ll}\text { c. Th17 assay } & \text { S38 }\end{array}$

$\begin{array}{lr}\text { 5. Molecular Modeling } & \text { S39 }\end{array}$

6. In vivo Pharmacology $\quad$ S40

6a. EAE model $\quad \mathrm{S} 40$

6b. IL-2 study $\quad$ S41

7. Physiochemical Properties and DMPK Assays S43

$\begin{array}{ll}\text { a. Solubility } & \text { S43 }\end{array}$

b. Hepatocyte Stability S43

c. Permeability Assay $\quad$ S44

$\begin{array}{ll}\text { 8. References } & \text { S45 }\end{array}$ 


\section{Chemistry and Synthetic Schemes}

The synthesis of 4-pyridylpyrazlopyridine $\mathbf{2}$ is depicted in Scheme 1. Of note, was the preparation and use of a 2-pyridylboronate stabilized by $N$-phenyldiethanolamine ${ }^{1} \mathbf{2 4}$ in a challenging Suzuki coupling reaction on route to $\mathbf{2}$. The general synthesis of 4-aryl pyrazolopyridines $\mathbf{3}$ - 22 involved construction of the bi-aryl bond by Suzuki-Miyaura cross coupling in the key step. This approach required the synthesis of 4-iodo- or 4boronato-pyrazolopyridines as one set of coupling partners and their general syntheses are outlined in Schemes 2 and 3. Commercially available 4-iodo- $1 H$-pyrazolo[3,4b]pyridine was chlorinated to provide intermediate $\mathbf{2 6}$ or tritylated giving regioisomers $\mathbf{2 7}$ and 29. Subsequent borylation of each gave key intermediates 28 and 30. 3-Alkyl-4iodopyrazolopyridines 35-37 were prepared by a halogen-dance strategy ${ }^{2}$ on 2-fluoro-3iodo-pyridine followed by oxidation and ring closure with hydrazine (Scheme 3). Syntheses of $\beta, \beta$-dialkylated amine analogs $\mathbf{8}$ - $\mathbf{1 1}$ are shown in Schemes 4 and 5. The general strategy involved deprotonation and alkylation of 2-(3-bromophenyl)acetonitrile with $\alpha, \omega$-dibromoalkanes for gem-cycloalkyl intermediates or sequential deprotonation/alkylation with different electrophiles for gem-dialkyl intermediates. This was followed by boronation, Suzuki-Miyaura coupling, nitrile reduction and trityl deprotection, the order of these transformations varying by compound. For example, in the case of 7, a second deprotonation/alkylation step was delayed until a later stage in the synthesis, in order to avoid carrying out palladium-mediated procedures on intermediates bearing a sensitive alkyne functional group. 
The general syntheses of pyrazolopyridines 12 - 14 and 18 containing trisubstituted arenes at position 4 are shown in Schemes 6 and 7. Key intermediate $\mathbf{6 8}$ was synthesized by a nucleophilic aromatic substitution reaction between ethylcyanoacetate and 1,3-dibromo-5-fluorobenzene followed by Krapcho decarboxylation. The same set of transformations as described previously delivered compound $\mathbf{1 8}$. Alkyl groups at C-5 on the arene ring were introduced by Suzuki reactions with either vinyl or propylboronic acid pinacol ester. Subsequent hydrogenation gave 13 and 14. Intermediate 82, on route to 12 was prepared by a nucleophilic aromatic substitution reaction on commercially available 3-bromo-5-(bromomethyl)-toluene with sodium cyanide. The syntheses of oxetane-containing analogs $\mathbf{2 1}$ and $\mathbf{2 2}$ are depicted in Scheme 9. The key step in the sequences involved rhodium(I)-catalyzed conjugate additions of organoboron reagents to ethyl 2-(oxetan-3-ylidene)acetate to construct the all carbon quaternary centers in $\mathbf{9 1}$ and 92. ${ }^{3,4}$ Of note, is that the reaction is compatible with a spectator aryl bromide. A Curtius rearrangement of acid $\mathbf{8 8}$ promoted by diphenylphosphorylazide gave $N$-Boc amine $\mathbf{9 8}$. Alternatively, the Curtius rearrangement could be carried out later in the sequence as shown in the preparation of analog 96. Subsequent elaboration using the same chemistry as before gave analogs $\mathbf{2 1}$ and $\mathbf{2 2}$. 
Scheme 1. Synthesis of compound $2^{\text {a }}$

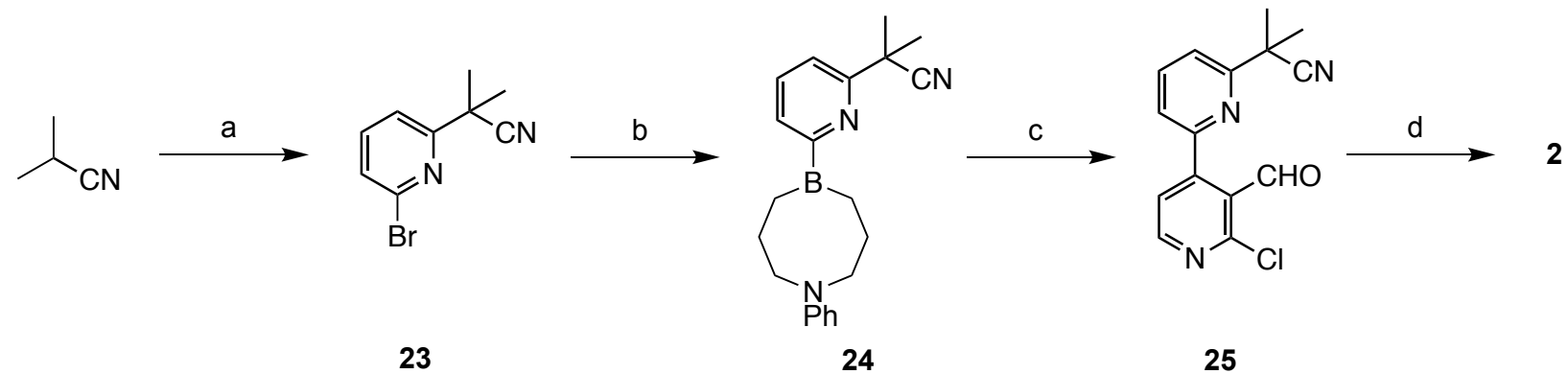

aReagents and conditions: (a) KHMDS, toluene, $0{ }^{\circ} \mathrm{C}$ to RT then 2,6-dibromopyridine, $\mathrm{RT}$; (b) $\left({ }^{\mathrm{i}} \mathrm{PrO}\right)_{3} \mathrm{~B}, \mathrm{n}-\mathrm{BuLi}, \mathrm{THF},-75^{\circ} \mathrm{C}$ to RT then $\mathrm{N}$-diphenyldiethanolamine, THF, reflux then $\mathrm{PrOH}$, reflux; (c) 2-chloro-4-iodonicotinaldehdye, tri-o-tolylphosphine, $\mathrm{Pd}(\mathrm{OAc})_{2}, \mathrm{CuI}, \mathrm{K}_{2} \mathrm{CO}_{3}$, THF, reflux; (d) $\mathrm{N}_{2} \mathrm{H}_{4} \cdot \mathrm{H}_{2} \mathrm{O}$, EtOH, microwave, $160{ }^{\circ} \mathrm{C}, 30 \mathrm{~min}$.

Scheme 2. Synthesis of pyrazolo[3,4-b]pyridine intermediates $\mathbf{2 6}$ - 30a

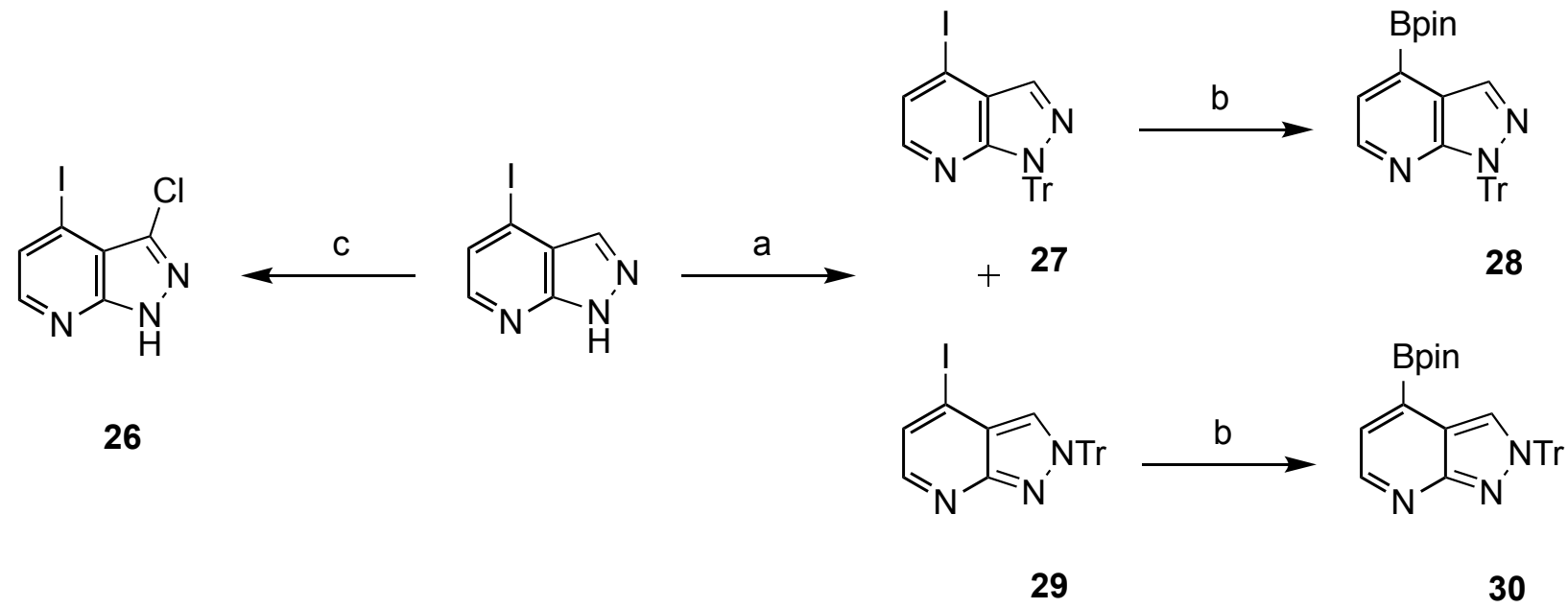

aReagents and conditions: (a) $\mathrm{NaH}, \mathrm{DMF}, 0{ }^{\circ} \mathrm{C}$ then $\mathrm{TrCl}$, DMF, $0{ }^{\circ} \mathrm{C}$ to RT; (b) (Bpin) $)_{2}, \mathrm{KOAc}, \operatorname{Pd}(\mathrm{dppf}) \mathrm{Cl}_{2}$.DCM, dioxane, reflux; (c) NCS, MeCN, reflux. 
Scheme 3. Synthesis of pyrazolo[3,4-b]pyridine intermediates 35-37 ${ }^{\text {a }}$

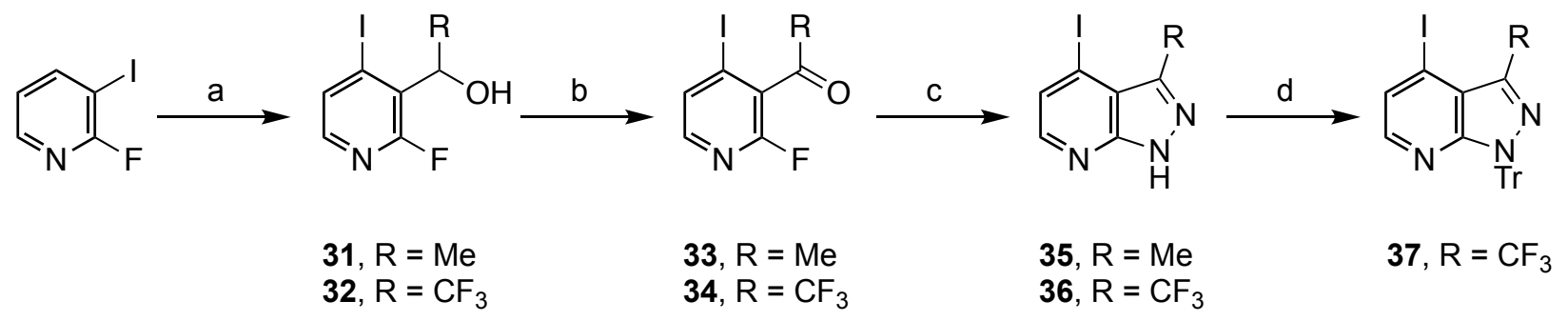

aReagents and conditions: (a) DIPA, ${ }^{\mathrm{n}} \mathrm{BuLi}, \mathrm{THF},-70{ }^{\circ} \mathrm{C}$ then acetaldehyde (for 31) or 2,2,2-trifluoroacetaldehyde (for 32); (b) $\mathrm{MnO}_{2}$, toluene, reflux; (c) $\mathrm{N}_{2} \mathrm{H}_{4}$, THF, $90{ }^{\circ} \mathrm{C}$ (for 35) or $\mathrm{N}_{2} \mathrm{H}_{4} \cdot \mathrm{H}_{2} \mathrm{O}$, dioxane, $90{ }^{\circ} \mathrm{C}$ (for 36); (d) $\mathrm{NaH}, \mathrm{DMF}, 0{ }^{\circ} \mathrm{C}$ then $\mathrm{TrCl}, 0{ }^{\circ} \mathrm{C}$ to RT. 
Scheme 4. Synthesis of amines $8-\mathbf{1 1}$ and 19a

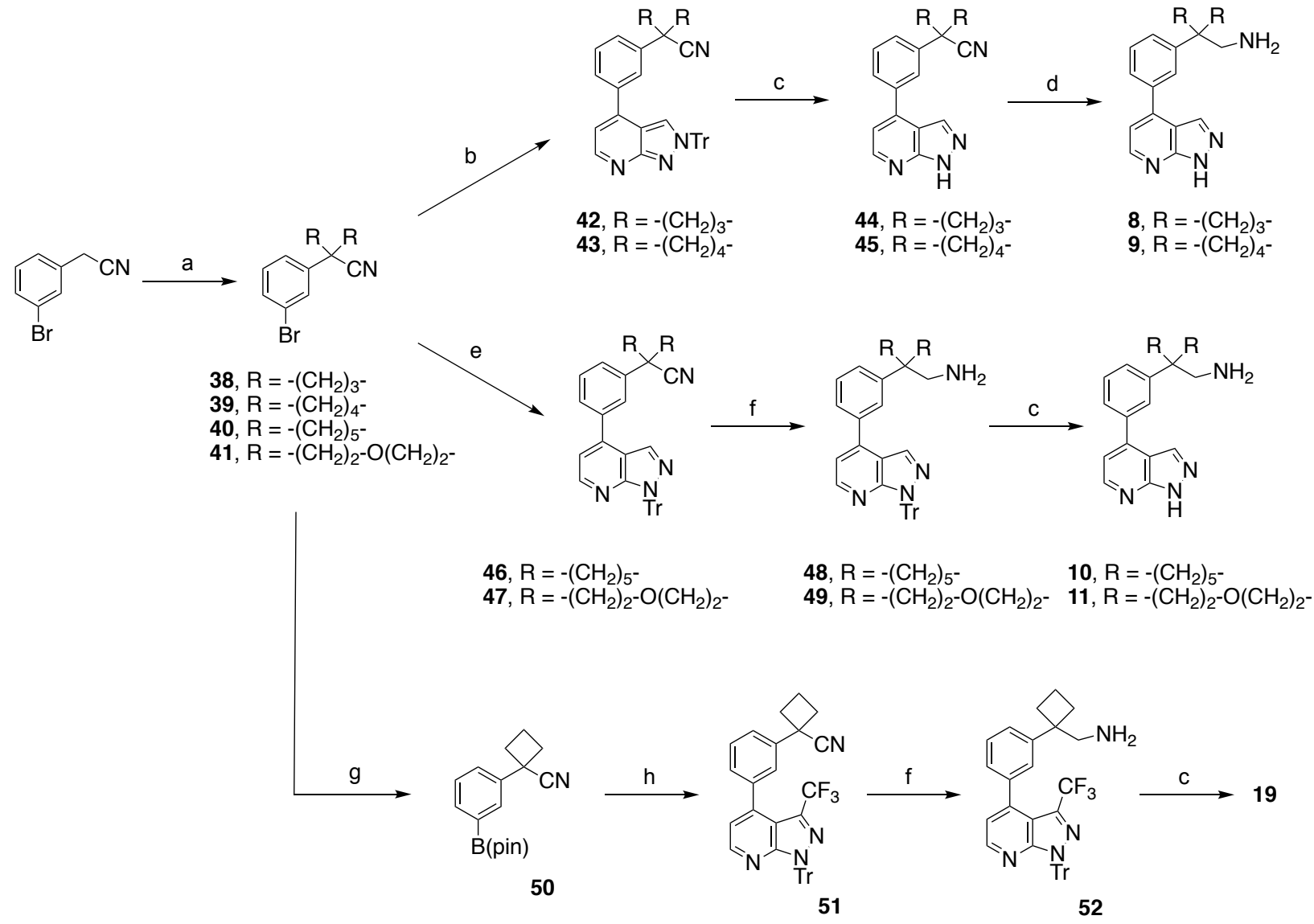

aReagents and conditions: (a) NaH, DMSO then $\alpha, \omega$-dibromoalkane, $0{ }^{\circ} \mathrm{C}$ to RT (for 38 - 40) or bis(2-chloroethyl)ether, RT (for 41); (b) 30, aq. $\mathrm{Na}_{2} \mathrm{CO}_{3}, \mathrm{Pd}\left[\mathrm{P}\left({ }^{\mathrm{t}} \mathrm{Bu}\right)_{3}\right]_{2}$, dioxane, $60{ }^{\circ} \mathrm{C}$; (c) TFA, Et $3 \mathrm{SiH}, \mathrm{DCM}, 0{ }^{\circ} \mathrm{C}$; (d) $\mathrm{LiAlH}_{4}, \mathrm{THF}, \mathrm{RT}$; (e) 28, aq. $\mathrm{Na}_{2} \mathrm{CO}_{3}$, $\mathrm{Pd}\left[\mathrm{P}\left({ }^{\mathrm{t} B u}\right)_{3}\right]_{2}$, dioxane, $60{ }^{\circ} \mathrm{C}$; (f) alane:dimethylethylamine complex, THF, $0{ }^{\circ} \mathrm{C}$ to $\mathrm{RT}$; $(\mathrm{g})$ (Bpin $)_{2}, \mathrm{KOAc}, \mathrm{Pd}(\mathrm{dppf}) \mathrm{Cl}_{2} . \mathrm{DCM}$, dioxane, reflux; (h) 37, aq. $\mathrm{Na}_{2} \mathrm{CO}_{3}, \mathrm{Pd}\left[\mathrm{P}\left({ }^{\mathrm{t}} \mathrm{Bu}\right)_{3}\right]_{2}$, dioxane, $60^{\circ} \mathrm{C}$. 
Scheme 5. Synthesis of compound $5-7$ and $\mathbf{1 5}-\mathbf{1 7}^{\text {a }}$
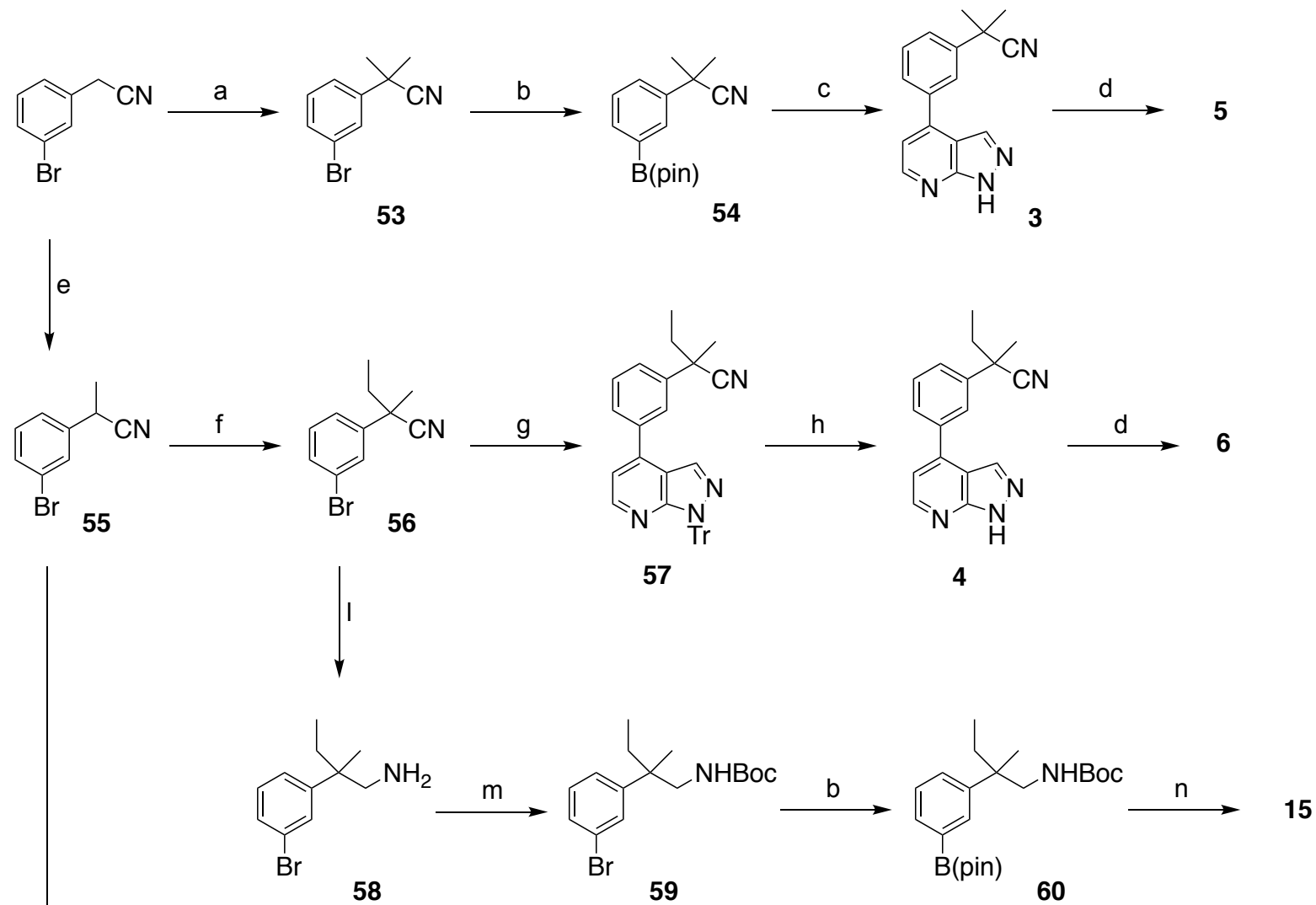

b
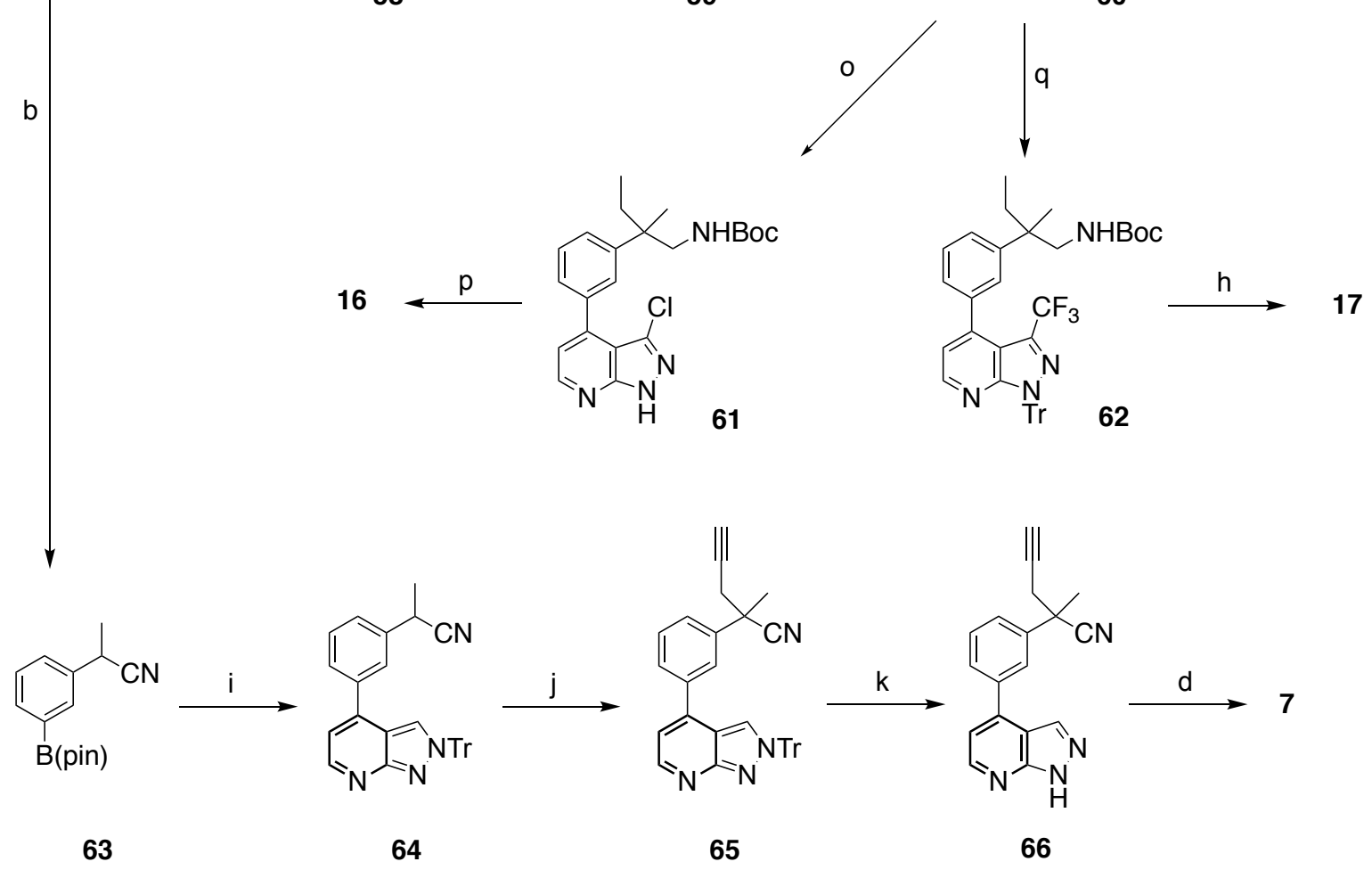
aReagents and conditions: (a) LiHMDS, THF, $0{ }^{\circ} \mathrm{C}$ then MeI, $0{ }^{\circ} \mathrm{C}$ to RT; (b) (Bpin) $)_{2}$, $\mathrm{KOAc}, \mathrm{Pd}(\mathrm{dppf}) \mathrm{Cl}_{2}$.DCM, DME, reflux; (c) 4-iodo-1 $H$-pyrazolo[3,4- $\left.b\right]$ pyridine, aq. $\mathrm{Na}_{2} \mathrm{CO}_{3}, \mathrm{Pd}\left(\mathrm{PPh}_{3}\right)_{4}, \mathrm{DME}, 150{ }^{\circ} \mathrm{C}$, microwave; (d) $\mathrm{LiAlH}_{4}$, THF; (e) $\mathrm{NaH}, \mathrm{THF}, 0{ }^{\circ} \mathrm{C}$ then MeI, $0{ }^{\circ} \mathrm{C}$; (f) $\mathrm{NaH}$, THF, $0{ }^{\circ} \mathrm{C}$ then EtI, $0{ }^{\circ} \mathrm{C}$; (g) 27, aq. $\mathrm{Na}_{2} \mathrm{CO}_{3}, \mathrm{Pd}\left[\mathrm{P}\left({ }^{\mathrm{t}} \mathrm{Bu}\right)_{3}\right]_{2}$, dioxane, RT; (h) TFA, Et ${ }_{3} \mathrm{SiH}, \mathrm{DCM}, 0{ }^{\circ} \mathrm{C}$; (i) 29, aq. $\mathrm{Na}_{2} \mathrm{CO}_{3}, \mathrm{Pd}\left[\mathrm{P}\left({ }^{\mathrm{t}} \mathrm{Bu}\right)_{3}\right]_{2}$, dioxane, 60 ${ }^{\circ} \mathrm{C}$; (j) $\mathrm{NaH}$, THF, $0{ }^{\circ} \mathrm{C}$ then propargyl bromide, $0{ }^{\circ} \mathrm{C}$ to $\mathrm{RT}$; (k) TFA, water, DCM, $\mathrm{MeOH}, 0{ }^{\circ} \mathrm{C}$ to RT; (l) Alane:dimethylethylamine complex, THF, $0{ }^{\circ} \mathrm{C}$ to RT; (m) (Boc) $)_{2} \mathrm{O}, \mathrm{NaHCO}_{3}$, THF, water, $0{ }^{\circ} \mathrm{C}$ to RT; (n) 35, aq. $\mathrm{Na}_{2} \mathrm{CO}_{3}, \mathrm{Pd}\left(\mathrm{PPh}_{3}\right)_{4}$, dioxane, 150 ${ }^{\circ} \mathrm{C}$, microwave then TFA, DCM, $0{ }^{\circ} \mathrm{C}$ to RT; (o) 26, aq. $\mathrm{Na}_{2} \mathrm{CO}_{3}, \mathrm{Pd}\left(\mathrm{PPh}_{3}\right)_{4}$, dioxane, 150 ${ }^{\circ} \mathrm{C}$, microwave; (p) TFA, DCM, $0{ }^{\circ} \mathrm{C}$ to RT; (q) 37, aq. $\mathrm{Na}_{2} \mathrm{CO}_{3}, \mathrm{Pd}\left[\mathrm{P}\left({ }^{\mathrm{t}} \mathrm{Bu}\right)_{3}\right]_{2}$, dioxane, 60 ${ }^{\circ} \mathrm{C}$;

Scheme 6. Synthesis of trisubstituted aryl analogs $13, \mathbf{1 4}$, and $18^{\mathrm{a}}$
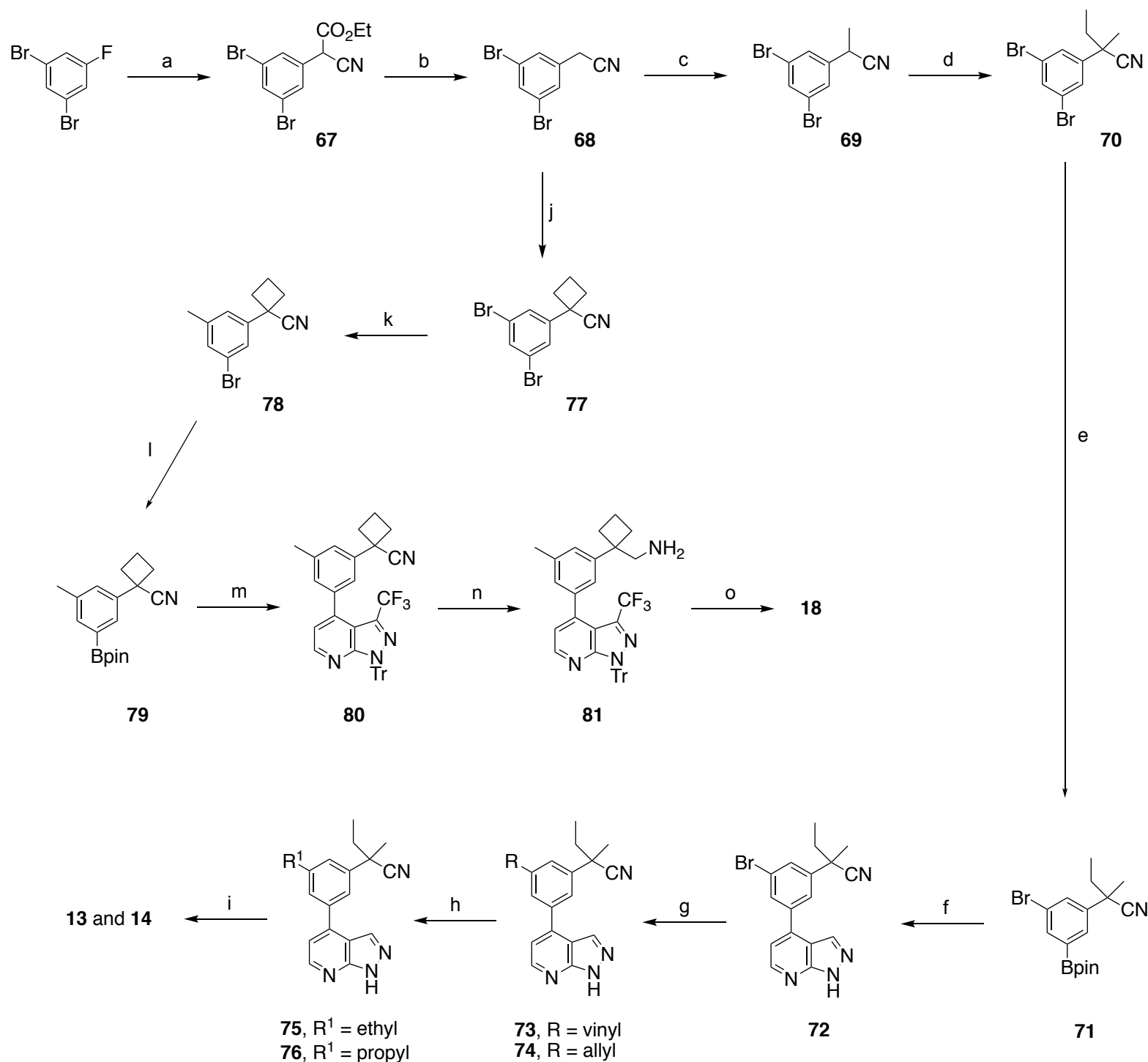
aReagents and conditions: (a) ethylcyanoacetate, NaH, NMP, $10-120{ }^{\circ} \mathrm{C}$; (b) $\mathrm{LiCl}$, DMSO, water, $165{ }^{\circ} \mathrm{C}$; (c) $\mathrm{NaH}$, THF, $0{ }^{\circ} \mathrm{C}$ then MeI, $0{ }^{\circ} \mathrm{C}$ to RT; (d) $\mathrm{NaH}$, THF, $0{ }^{\circ} \mathrm{C}$ then EtI, $0{ }^{\circ} \mathrm{C}$ to RT; (e) ${ }^{\mathrm{i}} \mathrm{PrMgCl} . \mathrm{LiCl}$, THF, $-20{ }^{\circ} \mathrm{C}$ then 2-methoxy-4,4,5,5-tetramethyl1,3,2-dioxaborolane, $-5{ }^{\circ} \mathrm{C}$ to RT; (f) 4-iodo- $1 H$-pyrazolo[3,4-b]pyridine, aq. $\mathrm{Na}_{2} \mathrm{CO}_{3}$, $\mathrm{Pd}\left(\mathrm{PPh}_{3}\right)_{4}, \mathrm{DME}, 150{ }^{\circ} \mathrm{C}$, microwave; (g) vinyl (for 73) or allyl (for 74) boronic acid pinacol ester, aq. $\mathrm{Na}_{2} \mathrm{CO}_{3}, \mathrm{Pd}\left(\mathrm{PPh}_{3}\right)_{4}, \mathrm{DME}, 150{ }^{\circ} \mathrm{C}$, microwave; (h) hydrogen, $10 \%$ $\mathrm{Pd} / \mathrm{C}, \mathrm{MeOH}$; (i) $\mathrm{LiAlH}_{4}$, THF, RT; (j) NaH, DMSO, RT then 1,3-dibromopropane, $0{ }^{\circ} \mathrm{C}$ to RT; (k) MeZnCl, $\mathrm{Pd}(\mathrm{dppf}) \mathrm{Cl}_{2} \mathrm{DCM}, \mathrm{CuI}, \mathrm{THF}, 150{ }^{\circ} \mathrm{C}$, microwave; (1) (Bpin) ${ }_{2}, \mathrm{KOAc}$, $\mathrm{Pd}(\mathrm{dppf}) \mathrm{Cl}_{2}$.DCM, dioxane, $90{ }^{\circ} \mathrm{C}$; (m) 37, aq. $\mathrm{Na}_{2} \mathrm{CO}_{3}$, $\mathrm{Pd}\left[\mathrm{P}(\mathrm{tBu})_{3}\right]_{2}$, dioxane, $60{ }^{\circ} \mathrm{C}$; (n) alane:dimethylethylamine complex, THF, $0{ }^{\circ} \mathrm{C}$ to RT; (o) TFA, $\mathrm{Et}_{3} \mathrm{SiH}, \mathrm{DCM}$.

Scheme 7. Synthesis of butanamine $12^{\mathrm{a}}$
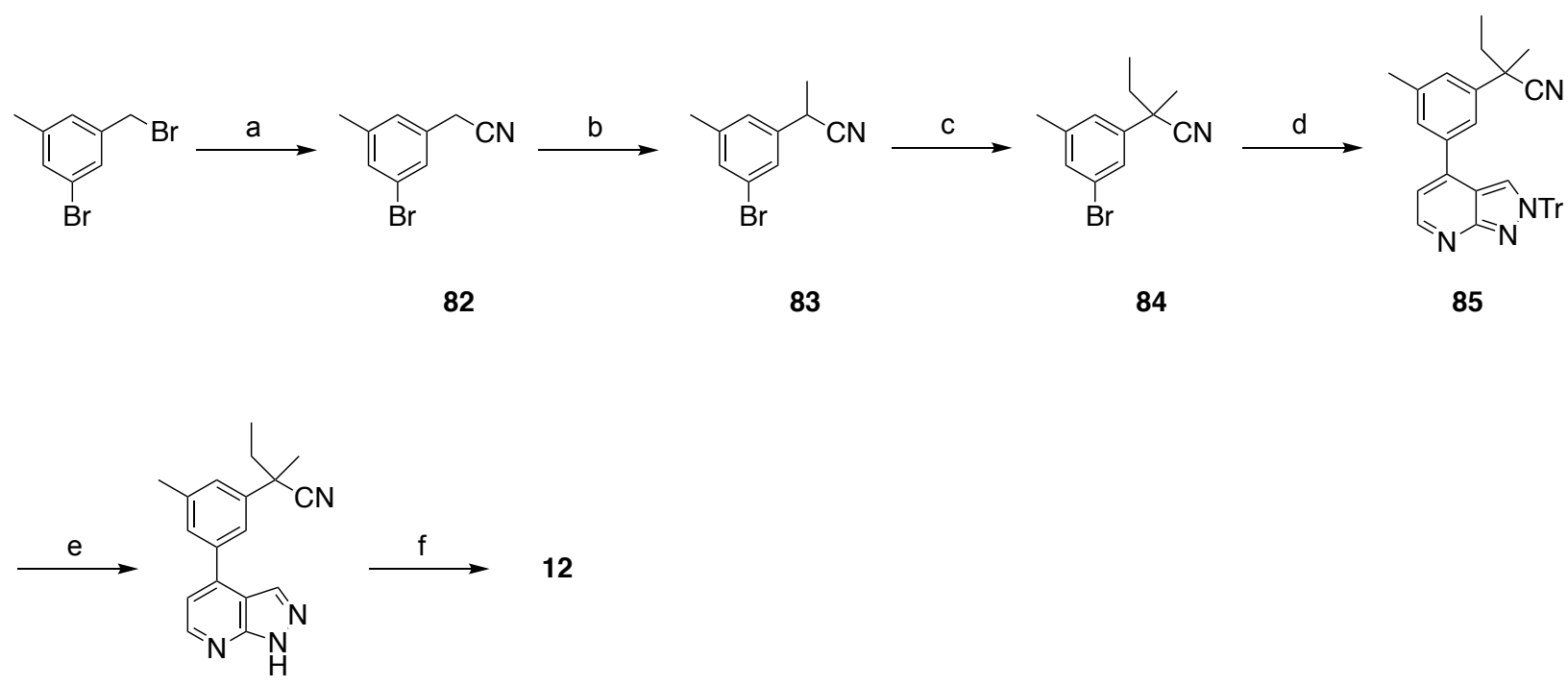

86

aReagents and conditions: (a) $\mathrm{NaCN}$, DMF, water, $100{ }^{\circ} \mathrm{C}$; (b) $\mathrm{NaH}$, THF, $0{ }^{\circ} \mathrm{C}$ then MeI, $0{ }^{\circ} \mathrm{C}$ to RT; (c) $\mathrm{NaH}$, THF, $0{ }^{\circ} \mathrm{C}$ then EtI, $0{ }^{\circ} \mathrm{C}$ to RT; (d) 30, aq. $\mathrm{Na}_{2} \mathrm{CO}_{3}$, $\mathrm{Pd}\left[\mathrm{P}(\mathrm{tBu})_{3}\right]_{2}$, dioxane, $60{ }^{\circ} \mathrm{C}$; (e) TFA, $\mathrm{Et}_{3} \mathrm{SiH}, \mathrm{DCM}, 0{ }^{\circ} \mathrm{C}$ to RT; (f) $\mathrm{LiAlH}_{4}$, THF, RT. 
Scheme 8. Synthesis of THF amine 20a

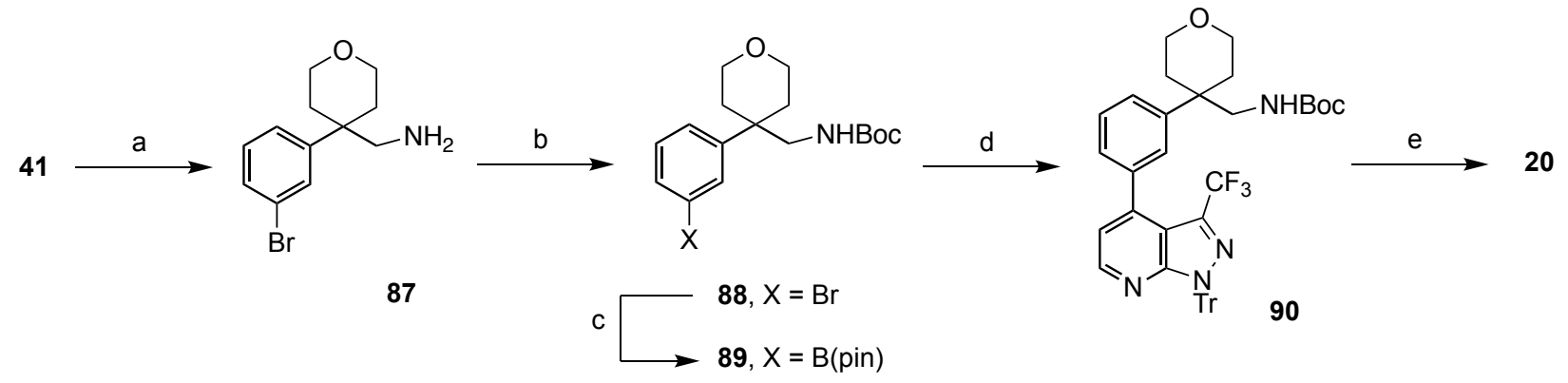

aReagents and conditions: (a) alane:dimethylamine complex, THF, $0{ }^{\circ} \mathrm{C}$ to RT; (b) (Boc) $)_{2} \mathrm{O}, \mathrm{NaHCO}_{3}$, THF, water, $0{ }^{\circ} \mathrm{C}$ to RT; (c) HBpin, $\mathrm{NEt}_{3}, \mathrm{Pd}(\mathrm{OAc})_{2}, \mathrm{CyJ}_{\mathrm{J}} \mathrm{HhPhos}, 80$ ${ }^{\circ} \mathrm{C}$; (d) 37, aq. $\mathrm{Na}_{2} \mathrm{CO}_{3}, \mathrm{Pd}\left[\mathrm{P}(\mathrm{tBu})_{3}\right]_{2}$, dioxane, $60{ }^{\circ} \mathrm{C}$; (e) TFA, $\mathrm{Et}_{3} \mathrm{SiH}, \mathrm{DCM}, 0{ }^{\circ} \mathrm{C}$ to RT. 
Scheme 9. Synthesis of (3-aryloxetan-3-yl)methanamines 21 and $\mathbf{2 2}^{\text {a }}$
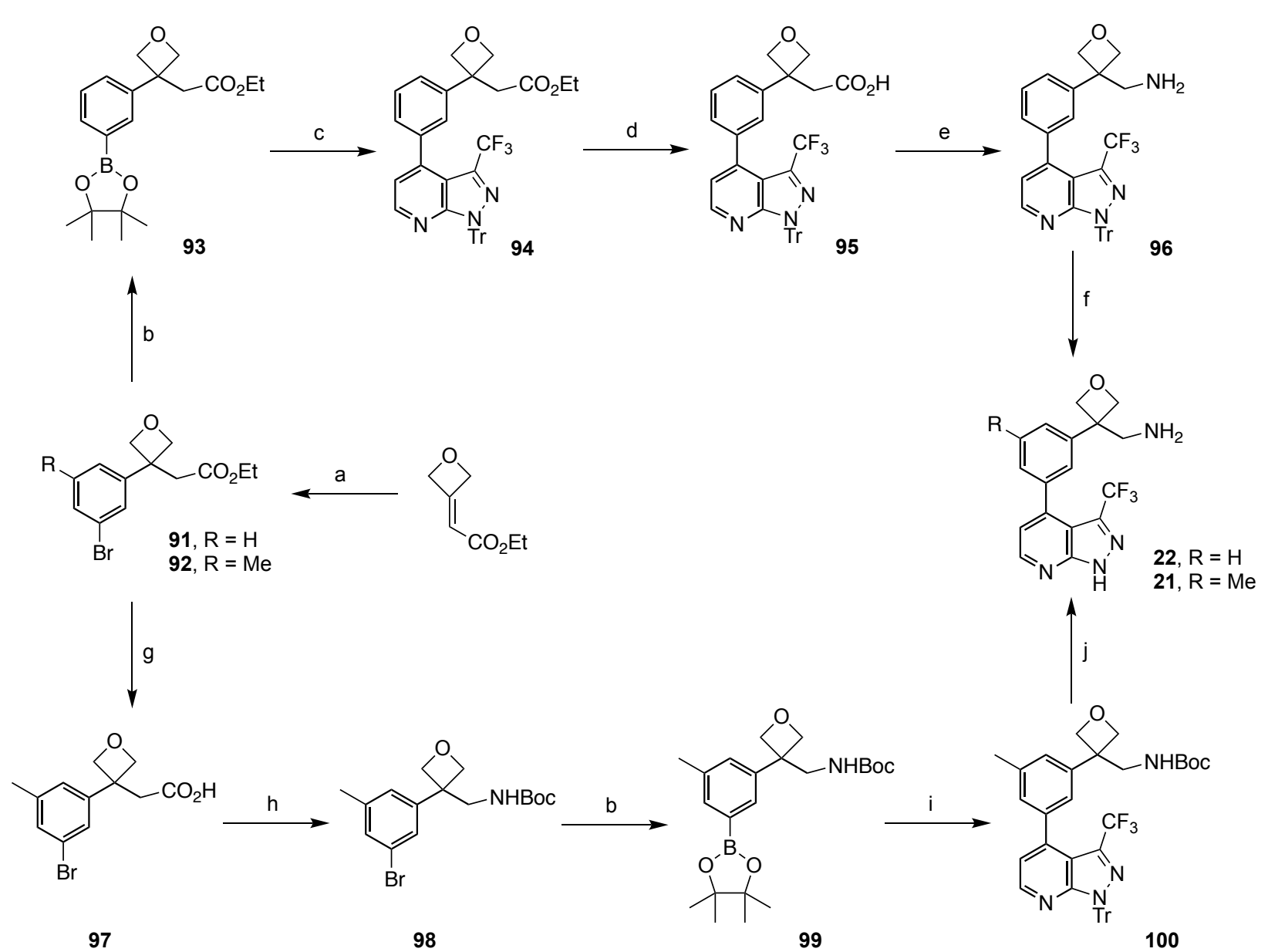

aReagents and conditions: (a) (3-bromophenyl)boronic acid (for 91) or (3-bromo-5methyl-phenyl)boronic acid (for 92), $[\mathrm{Rh}(\mathrm{cod}) \mathrm{Cl}]_{2}$, aq. $\mathrm{KOH}$, dioxane; (b) (Bpin) $)_{2}, \mathrm{KOAc}, \mathrm{Pd}(\mathrm{dppf}) \mathrm{Cl}_{2} . \mathrm{DCM}$, dioxane, $90{ }^{\circ} \mathrm{C}$; (c) 37, $\mathrm{Na}_{2} \mathrm{CO}_{3}, \mathrm{Pd}\left[\mathrm{P}\left({ }^{\mathrm{t}} \mathrm{Bu}\right)_{3}\right]_{2}$, dioxane, $60{ }^{\circ} \mathrm{C}$; (d) aq. $\mathrm{NaOH}, \mathrm{MeOH}$; (e) DPPA, $\mathrm{NEt}_{3}$, dioxane, $85^{\circ} \mathrm{C}$ then $\mathrm{LiOH}$; (f) TFA, $\mathrm{Et}_{3} \mathrm{SiH}, \mathrm{DCM}$; (g) aq. $\mathrm{NaOH}, \mathrm{MeOH} ; 0{ }^{\circ} \mathrm{C}$; (h) DPPA, $\mathrm{NEt}_{3},{ }^{\mathrm{t}} \mathrm{BuOH}, 80{ }^{\circ} \mathrm{C}$; (i) 37, $\mathrm{Na}_{2} \mathrm{CO}_{3}, \mathrm{Pd}\left(\mathrm{PPh}_{3}\right)_{4}$, dioxane, microwave, $150{ }^{\circ} \mathrm{C}$; (j) TFA, Et $\mathrm{SiH}_{3} \mathrm{DCM}$. 


\section{Synthetic Procedures and Compound Characterization}

All commercially available solvents and reagents were used as received. Microwave reactions were carried out using a CEM Discovery microwave. Analytical thin layer chromatography was carried out using glass-backed plates coated with Merck Kieselgel 60 GF240. Plates were visualized using UV light ( 254 or $366 \mathrm{~nm}$ ) and/or by staining with potassium permanganate followed by heating. Flash chromatography was carried out on an ISCO Combiflash Companion system, eluting with a $0-100 \%$ EtOAc/ petroleum ether gradient. Samples were applied preabsorbed on silica. Where stated, purification was performed using a Waters FractionLynx HPLC mass directed instrument using an appropriate acetonitrile/ water gradient with either TFA or ammonia modifier. ${ }^{1} \mathrm{H}$ NMR and ${ }^{19}$ F NMR spectra were recorded at 400 and $376 \mathrm{MHz}$, respectively, using a Bruker DPX 400 instrument. MS samples were analyzed on a MicroMass Quattro Micro mass spectrometer operating in single MS mode with electrospray ionization. Samples were introduced into the mass spectrometer using chromatography. High-resolution mass measurements were performed on a Thermo QExactive mass spectrometer with a heated electrospray source operated in positive ion mode. All final products had a purity of $>95 \%$. The purity of final products was determined by HPLC or combustion analyses. HPLC purity was measured on an Agilent HP1100 HPLC instrument with a Waters Quattro MS system equipped with an ACE C8 reverse phase column $(4.6 \mathrm{~mm} \times 150 \mathrm{~mm}, 5 \mu \mathrm{m})$. The mobile phases were acetonitrile/ methanol (1:1) and water (20 mM, pH 7.0, Tris phosphate). Combustion analyses were performed on a Control Equipment Corporation 440 elemental analyzer.

1-Trityl-4-(4,4,5,5-tetramethyl-1,3,2-dioxaborolan-2-yl)-1H-pyrazolo[3,4-b]pyridine (28). Step 1. 4-Iodo-lH-pyrazolo[3,4-b]pyridine (15 g, $61.2 \mathrm{mmol})$ was dissolved in DMF (300 mL) and the solution was cooled to $0-5^{\circ} \mathrm{C}$. Sodium hydride (60\% in mineral oil, $\left.2.94 \mathrm{~g}, 73.5 \mathrm{mmol}\right)$ was added portionwise and left to stir at this temperature for $2 \mathrm{~h}$. After this time, a solution of trityl chloride $(18.8 \mathrm{~g}, 67.3 \mathrm{mmol})$ in DMF $(150 \mathrm{~mL})$ was added dropwise over $30 \mathrm{~min}$. After an additional $2 \mathrm{~h}$ of stirring, the solvent was removed by evaporation, and the residue partitioned between ethyl acetate and sat. aq. $\mathrm{NaHCO}_{3}(2 \times 100 \mathrm{~mL})$. The organic layer was further washed with brine $(100 \mathrm{~mL})$, dried $\left(\mathrm{MgSO}_{4}\right)$ and concentrated in vacuo to give a brown oil. This residue was purified by silica gel flash chromatography to give 27 as a white solid $(13.7 \mathrm{~g}, 46 \%) .{ }^{1} \mathrm{H}$ NMR (400 MHz, DMSO- $\left.d_{6}\right) \delta 8.10(\mathrm{~s}, 1 \mathrm{H}), 7.89(\mathrm{~d}, J=4.8 \mathrm{~Hz}, 1 \mathrm{H}), 7.59(\mathrm{~d}, J=4.8 \mathrm{~Hz}, 1 \mathrm{H})$, 7.31-7.16 (m, 15H); Mass spectrum (ESI) $m / z 488.0[\mathrm{M}+\mathrm{H}]^{+}$.

$29(8.06 \mathrm{~g}, 27 \%)$ was also retrieved from the above column as a pale yellow solid. ${ }^{1} \mathrm{H}$ NMR (400 $\left.\mathrm{MHz}, \mathrm{DMSO}-d_{6}\right) \delta 8.28(\mathrm{~d}, J=4.4 \mathrm{~Hz}, 1 \mathrm{H}), 7.78(\mathrm{~s}, 1 \mathrm{H}), 7.64(\mathrm{~d}, J=4.4 \mathrm{~Hz}, 1 \mathrm{H}), 7.45-7.41(\mathrm{~m}$, 9H), 7.14-7.11 (m, 6H). Mass spectrum (ESI) $\mathrm{m} / z$ 488.0 [M + H $]^{+}$.

Step 2. A mixture of $27(9.61 \mathrm{~g}, 19.7 \mathrm{mmol})$, potassium acetate $(5.81 \mathrm{~g}, 59.2 \mathrm{mmol})$ and bis(pinacol)diboron $(6.01 \mathrm{~g}, 23.7 \mathrm{mmol})$ was dissolved in dioxane $(100 \mathrm{~mL})$. Nitrogen was bubbled through the reaction mixture for $20 \mathrm{~min}$ then $\mathrm{Pd}(\mathrm{dppf}) \mathrm{Cl}_{2} \cdot \mathrm{CH}_{2} \mathrm{Cl}_{2}(805 \mathrm{mg}, 0.99 \mathrm{mmol})$ was added in one portion and the reaction mixture was sealed and heated to $120^{\circ} \mathrm{C}$ behind a blast shield for $24 \mathrm{~h}$. The reaction mixture was cooled to room temperature, filtered through a path of Celite and washed with ethyl acetate. The filtrate was concentrated in vacuo and the residue was purified by silica gel flash chromatography to give $28(7.08 \mathrm{~g}, 74 \%)$ as a beige solid. ${ }^{1} \mathrm{H}$ NMR $\left(400 \mathrm{MHz}, \mathrm{DMSO}-d_{6}\right) \delta 8.25-8.29(\mathrm{~m}, 2 \mathrm{H}), 7.19-7.32(\mathrm{~m}, 16 \mathrm{H}), 1.35$ (s, 12H); LRMS found for $\mathrm{M}^{+}+1,488.0, \mathrm{C}_{31} \mathrm{H}_{31} \mathrm{BN}_{3} \mathrm{O}_{2}$ requires 488.3.

2-Trityl-4-(4,4,5,5-tetramethyl-1,3,2-dioxaborolan-2-yl)-2H-pyrazolo[3,4-b]pyridine (30).

Step 1. 29 (10.3 g, $21.2 \mathrm{mmol})$, potassium acetate (6.24 g, $63.5 \mathrm{mmol})$, bis(pinacol)diboron (6.46 
g, $25.4 \mathrm{mmol})$ and $\mathrm{Pd}(\mathrm{dppf}) \mathrm{Cl}_{2} \cdot \mathrm{CH}_{2} \mathrm{Cl}_{2}(865 \mathrm{mg}, 1.06 \mathrm{mmol})$ were suspended/dissolved in dry dioxane $(100 \mathrm{~mL})$ and degassed by vacuum / nitrogen cycles (x5). The resultant mixture was stirred at $110^{\circ} \mathrm{C}$ overnight and then allowed to cool to room temperature. The solvent was removed in vacuo. The residue was purified by chromatography on Florisil (10-50\% ethyl acetate in hexanes) to give an orange-red gum. This material was triturated in refluxing cyclohexane and allowed to cool under a nitrogen atmosphere overnight and the solid was collected by filtration and washed with pentane $(3 \times 10 \mathrm{~mL})$ to give $30(7.15 \mathrm{~g}, 69 \%)$ as a light salmon-pink powder. ${ }^{1} \mathrm{H}$ NMR $\left(400 \mathrm{MHz}, \mathrm{DMSO}-d_{6}\right) \delta 8.29(\mathrm{~s}, 1 \mathrm{H}), 8.26(\mathrm{~d}, J=4.4 \mathrm{~Hz}, 1 \mathrm{H}), 7.31(\mathrm{~d}, J=4.4 \mathrm{~Hz}, 1 \mathrm{H})$, 7.28-7.17 (m, 5H), $1.35(\mathrm{~s}, 2 \mathrm{H})$. LRMS found for $\mathrm{M}^{+}+1,488.2, \mathrm{C}_{31} \mathrm{H}_{31} \mathrm{BN}_{3} \mathrm{O}_{2}$ requires 488.3.

3-Chloro-4-iodo-1H-pyrazolo[3,4-b]pyridine (26). Step 1. 4-Iodo-1H-pyrazolo[3,4-b]pyridine (1 g, $4.08 \mathrm{mmol}$ ) and NCS (654 $\mathrm{mg}, 4.90 \mathrm{mmol})$ were dissolved/suspended in dry acetonitrile (20 $\mathrm{mL}$ ) and refluxed overnight. The reaction mixture was allowed to cool to room temperature and concentrated in vacuo to give a dark yellow solid. This material was partitioned between ethyl acetate $(300 \mathrm{~mL})$ and brine. The organic layer was washed with brine $(50 \mathrm{~mL})$, saturated aqueous $\mathrm{Na}_{2} \mathrm{~S}_{2} \mathrm{O}_{3}(50 \mathrm{~mL})$ and brine $(50 \mathrm{~mL})$ then dried $\left(\mathrm{Na}_{2} \mathrm{SO}_{4}\right)$, filtered and concentrated in vacuo. The resulting solid was purified by column chromatography ( $25 \%$ ethyl acetate in DCM) to give 26 (641 mg, 56\%) as a white solid. ${ }^{1} \mathrm{H}$ NMR (400 MHz, DMSO- $\left.d_{6}\right) \delta 14.22$ (br s, $\left.1 \mathrm{H}\right), 8.23$ (d, $J=$ $4.8 \mathrm{~Hz}, 1 \mathrm{H}) .7 .87(\mathrm{~d}, J=4.8 \mathrm{~Hz}, 1 \mathrm{H})$. LRMS found for $\mathrm{M}^{+}+1,279.8, \mathrm{C}_{6} \mathrm{H}_{4} \mathrm{ClN}_{3}$ requires 279.9.

\section{2-(6-(1 H-Pyrazolo[3,4-b]pyridin-4-yl)pyridin-2-yl)-2-methylpropanenitrile (2). Step 1.}

Potassium bis(trimethylsilyl)amide $(0.5 \mathrm{M}$ in toluene, $100 \mathrm{mmol})$ was added slowly to a solution of isobutyronitrile $(8.55 \mathrm{ml}, 95.3 \mathrm{mmol})$ in toluene $(200 \mathrm{~mL})$ at $0{ }^{\circ} \mathrm{C}$. After the addition was complete, the reaction mixture was allowed to warm to room temperature over $1 \mathrm{~h}$. The resulting mixture was added to a solution of 2,6-dibromopyridine $(56.4 \mathrm{~g}, 238 \mathrm{mmol})$ in toluene $(100 \mathrm{ml})$ and the reaction mixture was stirred for $18 \mathrm{~h}$. The crude mixture was diluted with ether, washed with a saturated aqueous solution of ammonium chloride and brine. The organic phase was dried $\left(\mathrm{MgSO}_{4}\right)$, filtered and concentrated in vacuo. The residue was purified on silica gel by flash column chromatography to afford $23(14.0 \mathrm{~g}, 65 \%)$ as an oil. ${ }^{1} \mathrm{H}$ NMR (400 MHz, DMSO- $\left.d_{6}\right) \delta$ $7.91-7.81(\mathrm{~m}, 1 \mathrm{H}), 7.70-7.61(\mathrm{~m}, 2 \mathrm{H}), 1.69(\mathrm{~d}, J=0.9 \mathrm{~Hz}, 6 \mathrm{H})$. LRMS found for $\mathrm{M}^{+}+1$, 279.2, $\mathrm{C}_{17} \mathrm{H}_{19} \mathrm{~N}_{4}$ requires 279.2.

Step 2. A solution of $27(1 \mathrm{~g}, 4.44 \mathrm{mmol})$ and triisopropylborate $(1.23 \mathrm{ml}, 5.33 \mathrm{mmol})$ in THF (10 $\mathrm{mL})$ was cooled to $-75^{\circ} \mathrm{C}$ then $\mathrm{n}-\mathrm{BuLi}(2.5 \mathrm{M}$ in hexanes, $5.77 \mathrm{mmol})$ was added at such a rate that the temperature did not exceed $-67^{\circ} \mathrm{C}$. After addition was complete, the reaction was allowed to warm to room temperature and stirred for $16 \mathrm{~h}$. After this time, a solution of Nphenyldiethanolamine $(805 \mathrm{mg}, 4.44 \mathrm{mmol})$ in THF $(8 \mathrm{~mL})$ was added and the resulting mixture was heated at reflux for $4 \mathrm{~h}$. The mixture was concentrated in vacuo, diluted with isopropanol (18 $\mathrm{mL}$ ) and refluxed for $1 \mathrm{~h}$. The reaction mixture was cooled to room temperature and stirred for 18 hours. The newly formed solid was filtered and dried in vacuo at $40^{\circ} \mathrm{C}$ to afford $\mathbf{2 4}(880 \mathrm{mg}$, $59 \%$ ) as a white solid complexed with 1eq. of isopropanol. ${ }^{1} \mathrm{H}$ NMR (400 MHz, $\left.\mathrm{CD}_{3} \mathrm{OD}\right) \delta 7.67-$ $7.55(\mathrm{~m}, 1 \mathrm{H}), 7.56-7.44(\mathrm{~m}, 1 \mathrm{H}), 7.33(\mathrm{dt}, J=7.8,1.3 \mathrm{~Hz}, 1 \mathrm{H}), 7.21-7.13(\mathrm{~m}, 2 \mathrm{H}), 6.81-6.70(\mathrm{~m}$, $2 \mathrm{H}), 6.70-6.57(\mathrm{~m}, 1 \mathrm{H}), 4.07-3.84(\mathrm{~m}, 1 \mathrm{H}), 3.81-3.67(\mathrm{~m}, 4 \mathrm{H}), 3.54(\mathrm{t}, J=6.1 \mathrm{~Hz}, 4 \mathrm{H}), 1.79(4 \mathrm{H}$, app s), 1.17 (dd, $J=6.2,1.2 \mathrm{~Hz}, 6 \mathrm{H})$.

Step 3. A mixture of 2-chloro-4-iodonicotinaldehyde ${ }^{1}$ (90.3 mg, $\left.0.338 \mathrm{mmol}\right), 24$ (226 mg, 0.675 mmol), tri-o-tolylphosphine ( $21 \mathrm{mg}, 0.068 \mathrm{mmol})$, palladium acetate $(5 \mathrm{~mol} \%, 3.8 \mathrm{mg}, 0.017$ $\mathrm{mmol})$, potassium carbonate $(93 \mathrm{mg}, 0.675 \mathrm{mmol})$ and copper(I) iodide $(26 \mathrm{mg}, 0.135 \mathrm{mmol})$ in THF ( $5 \mathrm{ml}$ ) was heated at reflux under nitrogen for $75 \mathrm{~min}$. The mixture was cooled to room temperature, filtered through a path of Celite and evaporated to dryness. The residue was purified on silica gel by flash column chromatography to afford $25(71 \mathrm{mg}, 74 \%)$ as an off-white solid. ${ }^{1} \mathrm{H}$ $\operatorname{NMR}\left(400 \mathrm{MHz}, \mathrm{CDCl}_{3}\right) \delta 10.39(\mathrm{~s}, 1 \mathrm{H}), 8.74-8.51(\mathrm{~m}, 1 \mathrm{H}), 7.95(\mathrm{dd}, J=8.4,7.3 \mathrm{~Hz}, 1 \mathrm{H}), 7.76$ 
- $7.66(\mathrm{~m}, 2 \mathrm{H}), 7.58(\mathrm{dd}, J=5.0,1.1 \mathrm{~Hz}, 1 \mathrm{H}), 1.76(\mathrm{~d}, J=1.0 \mathrm{~Hz}, 6 \mathrm{H})$. LRMS found for $\mathrm{M}^{+}+1$, 286.7, $\mathrm{C}_{15} \mathrm{H}_{13} \mathrm{ClN}_{3} \mathrm{O}$ requires 286.1.

Step 4. A mixture of 29 (71 $\mathrm{mg}, 0.25 \mathrm{mmol})$ and hydrazine (1M solution in THF, $3 \mathrm{mmol}$ ) was heated under microwave irradiation at $140{ }^{\circ} \mathrm{C}$ for $20 \mathrm{~min}$. Because the reaction had not gone to completion, ethanol $(1 \mathrm{~mL})$ and hydrazine hydrate $(1 \mathrm{~mL})$ were added and the reaction mixture microwaved at $160{ }^{\circ} \mathrm{C}$ for $30 \mathrm{~min}$. The mixture was cooled to room temperature and partitioned between ethyl acetate and water. The organic phase was dried $\left(\mathrm{MgSO}_{4}\right)$, filtered and concentrated. The residue was purified on silica gel by flash column chromatography to afford 2 (14.6 mg, 22\%) as a white solid. ${ }^{1} \mathrm{H}$ NMR $\left(400 \mathrm{MHz}, \mathrm{CDCl}_{3}\right) \delta 13.80(\mathrm{~s}, 1 \mathrm{H}), 8.89(\mathrm{~s}, 1 \mathrm{H}), 8.67$ $(\mathrm{d}, J=4.9 \mathrm{~Hz}, 1 \mathrm{H}), 8.27(\mathrm{~d}, J=7.9 \mathrm{~Hz}, 1 \mathrm{H}), 8.12(\mathrm{t}, J=7.9 \mathrm{~Hz}, 1 \mathrm{H}), 7.84(\mathrm{~d}, J=4.9 \mathrm{~Hz}, 1 \mathrm{H})$, $7.73(\mathrm{~d}, J=7.9 \mathrm{~Hz}, 1 \mathrm{H}), 1.83(\mathrm{~s}, 6 \mathrm{H})$; HRMS found for $\mathrm{M}^{+}+1,264.1242, \mathrm{C}_{15} \mathrm{H}_{14} \mathrm{~N}_{5}$ requires 264.1244 .

2-(3-(1H-Pyrazolo[3,4-b]pyridin-4-yl)phenyl)-2-methylpropanenitrile (3). Step 1. Lithiumbis(trimethylsilyl)amide (1 M in THF, $58.7 \mathrm{mmol}$ ) was added slowly to a solution of 2(3-bromophenyl)acetonitrile $(5.75 \mathrm{~g}, 29.3 \mathrm{mmol})$ in THF $(60 \mathrm{~mL})$ at $0{ }^{\circ} \mathrm{C}$. After $20 \mathrm{~min}$, methyl iodide $(9.14 \mathrm{ml}, 147 \mathrm{mmol})$ was added and the reaction mixture was then stirred at room temperature for $1 \mathrm{~h}$. The crude mixture was quenched with water and extracted with ethyl acetate. The organic phase was washed with brine, dried $\left(\mathrm{MgSO}_{4}\right)$, filtered and concentrated in vacuo. The residue was purified on silica gel by flash column chromatography to afford $\mathbf{5 3}$ (6.63 g, $100 \%$ ) as a colorless oil. ${ }^{1} \mathrm{H}$ NMR $\left(400 \mathrm{MHz}, \mathrm{MeOH}-d_{4}\right) \delta 7.44(\mathrm{t}, J=1.9 \mathrm{~Hz}, 1 \mathrm{H}), 7.33-7.24(\mathrm{~m}$, 2H), 7.15-7.06 (m, 1H), $1.57(\mathrm{~s}, 6 \mathrm{H})$; LRMS found for $\mathrm{M}^{+}+1,225.1, \mathrm{C}_{10} \mathrm{H}_{11}$ BrN requires 224.0. Step 2. A suspension of $\mathbf{5 3}$ (6.33 g, $28.3 \mathrm{mmol}$ ), bis(pinacolato)diboron (8.61 g, $33.90 \mathrm{mmol})$, potassium acetate ( $8.32 \mathrm{~g}, 84.8 \mathrm{mmol}), 1,1$ '-bis(diphenylphosphino)ferrocene-

palladium(II)dichloride dichloromethane complex $(692 \mathrm{mg}, 0.85 \mathrm{mmol})$ in DME (120 mL) was heated at reflux under nitrogen for $30 \mathrm{~min}$. The mixture was cooled to room temperature, filtered through a path of Celite and concentrated. The residue was purified by silica gel flash column chromatography to give $\mathbf{5 4}(6.39 \mathrm{~g}, 83 \%)$ as a white solid. ${ }^{1} \mathrm{H}$ NMR $\left(400 \mathrm{MHz}, \mathrm{CD}_{3} \mathrm{OD}\right) \delta 7.93$ $7.84(\mathrm{~m}, 1 \mathrm{H}), 7.83-7.72(\mathrm{~m}, 1 \mathrm{H}), 7.62(\mathrm{ddd}, J=7.9,2.3,1.3 \mathrm{~Hz}, 1 \mathrm{H}), 7.42(\mathrm{t}, J=7.7 \mathrm{~Hz}, 1 \mathrm{H})$, $1.77(\mathrm{~s}, 6 \mathrm{H}), 1.37(\mathrm{~s}, 12 \mathrm{H})$; LRMS found for $\mathrm{M}^{+}+1,272.0, \mathrm{C}_{16} \mathrm{H}_{23} \mathrm{BNO}_{2}$ requires 272.2.

Step 3. A suspension of 4-iodo-lH-pyrazolo[3,4-b]pyridine (50 mg, $0.204 \mathrm{mmol}), 54$ (66 mg, $0.245 \mathrm{mmol})$, aq. $\mathrm{Na}_{2} \mathrm{CO}_{3}(2 \mathrm{M}, 0.612 \mathrm{mmol}), \mathrm{Pd}\left(\mathrm{PPh}_{3}\right)_{4}(12 \mathrm{mg}, 0.01 \mathrm{mmol})$, in DME (2.5 ml) was heated under microwave irradiation at $150{ }^{\circ} \mathrm{C}$ for $30 \mathrm{~min}$. The mixture was cooled to room temperature, filtered through a pad of Celite and concentrated. The residue was partitioned between ethyl acetate and water and the organic phase dried $\left(\mathrm{MgSO}_{4}\right)$, filtered and concentrated. Purified by silica gel flash chromatography gave $3(28.4 \mathrm{mg}, 53 \%)$ as a white solid. ${ }^{1} \mathrm{H}$ NMR $\left(400 \mathrm{MHz}, \mathrm{DMSO}-d_{6}\right) \delta 13.85(\mathrm{~s}, 1 \mathrm{H}), 8.62(\mathrm{dd}, J=4.8,1.2 \mathrm{~Hz}, 1 \mathrm{H}), 8.31(\mathrm{~d}, J=1.0 \mathrm{~Hz}, 1 \mathrm{H})$, $7.96(\mathrm{~d}, J=1.9 \mathrm{~Hz}, 1 \mathrm{H}), 7.90-7.82(\mathrm{~m}, 1 \mathrm{H}), 7.76-7.62(\mathrm{~m}, 2 \mathrm{H}), 7.42(\mathrm{dd}, J=4.8,1.2 \mathrm{~Hz}, 1 \mathrm{H})$, $1.79(\mathrm{~s}, 6 \mathrm{H})$; HRMS found for $\mathrm{M}^{+}+1,263.1296, \mathrm{C}_{16} \mathrm{H}_{15} \mathrm{~N}_{4}$ requires 263.1291 .

2-(3-(1H-Pyrazolo[3,4-b]pyridin-4-yl)phenyl)-2-methylbutanenitrile (4). Step 1 . To a solution of 3-bromophenylacetonitrile $(12 \mathrm{~g}, 61.2 \mathrm{mmol})$ in THF $(150 \mathrm{~mL})$ at $0{ }^{\circ} \mathrm{C}$, was added sodium hydride (60\% in mineral oil, $2.25 \mathrm{~g}, 56.3 \mathrm{mmol})$ portionwise over $10 \mathrm{~min}$. The reaction mixture was stirred at $0{ }^{\circ} \mathrm{C}$ for $40 \mathrm{~min}$. Methyl iodide $(5.71 \mathrm{ml}, 91.8 \mathrm{mmol})$ was added dropwise at $0{ }^{\circ} \mathrm{C}$ and the reaction mixture was stirred at the same temperature for a further $1 \mathrm{~h}$. The reaction mixture was diluted with ethyl acetate $(250 \mathrm{~mL})$ and washed with water and brine. The organic phase was dried $\left(\mathrm{MgSO}_{4}\right)$, filtered and concentrated in vacuo. The residue was purified by silica gel flash chromatography (ISCO Companion, $330 \mathrm{~g}$ column, 0-20\% ethyl acetate/Petroleum ether) to give 55 (7.06 g, 55\%) as a colorless oil. ${ }^{1} \mathrm{H}$ NMR (400 MHz, DMSO- $\left.d_{6}\right) \delta 7.64(\mathrm{~s}, 1 \mathrm{H})$, 
$7.57(\mathrm{~d}, J=7.6 \mathrm{~Hz}, 1 \mathrm{H}), 7.46-7.37(\mathrm{~m}, 2 \mathrm{H}), 4.35(\mathrm{q}, J=7.2 \mathrm{~Hz}, 1 \mathrm{H}), 1.55(\mathrm{~d}, J=7.2 \mathrm{~Hz}, 3 \mathrm{H})$. LRMS found for $[\mathrm{M}-\mathrm{CN}]^{+}, 185.0, \mathrm{C}_{8} \mathrm{H}_{9} \mathrm{Br}$ requires 185.0.

Step 2. To a solution of $\mathbf{5 5}(600 \mathrm{mg}, 3.06 \mathrm{mmol})$ in THF $(15 \mathrm{~mL})$ at $0{ }^{\circ} \mathrm{C}$, was added sodium hydride $(60 \%$ in mineral oil, $184 \mathrm{mg}, 4.59 \mathrm{mmol})$ in one portion. The reaction mixture was stirred at $0{ }^{\circ} \mathrm{C}$ for $40 \mathrm{~min}$. Ethyl iodide $(0.49 \mathrm{ml}, 6.12 \mathrm{mmol})$ was added dropwise at $0{ }^{\circ} \mathrm{C}$ and the reaction mixture was stirred at $0{ }^{\circ} \mathrm{C}$ for a further $2 \mathrm{~h}$. The reaction mixture was diluted with ethyl acetate $(250 \mathrm{~mL})$ and washed with water and brine. The organic phase was dried $\left(\mathrm{MgSO}_{4}\right)$, filtered and concentrated in vacuo. The residue was purified by silica gel flash chromatography (ISCO Companion, $40 \mathrm{~g}$ column, $0-10 \%$ ethyl acetate/Petroleum ether) to give $56(0.526 \mathrm{~g}, 72 \%)$ as a colorless sticky oil. ${ }^{1} \mathrm{H}$ NMR $\left(400 \mathrm{MHz}, \mathrm{DMSO}-d_{6}\right) \delta 7.65(\mathrm{t}, J=1.2 \mathrm{~Hz}, 1 \mathrm{H}), 7.58-7.55(\mathrm{~m}$, $1 \mathrm{H}), 7.51(\mathrm{dd}, J=8.0,1.2 \mathrm{~Hz}, 1 \mathrm{H}), 7.41(\mathrm{t}, J=8.0 \mathrm{~Hz}, 1 \mathrm{H}), 1.98(\mathrm{q}, J=7.2 \mathrm{~Hz}, 2 \mathrm{H}), 1.68(\mathrm{~s}$, $3 \mathrm{H}), 0.84\left(\mathrm{t}, J=7.2 \mathrm{~Hz}, 3 \mathrm{H}\right.$ ). LRMS found for $[\mathrm{M}-\mathrm{CN}]^{+}, 213.0, \mathrm{C}_{10} \mathrm{H}_{13} \mathrm{Br}$ requires 212.0.

Step 3. A suspension of 27 (307 mg, $0.63 \mathrm{mmol}), \mathbf{5 6}(150 \mathrm{mg}, 0.63 \mathrm{mmol})$ and aq. $\mathrm{Na}_{2} \mathrm{CO}_{3}(2 \mathrm{M}$, $0.945 \mathrm{ml}, 1.89 \mathrm{mmol})$ in dioxane $(4 \mathrm{~mL})$ was degassed by vacuum/nitrogen cycling (five times). Bis(tri-tert-butylphosphine)palladium(0) $(16.1 \mathrm{mg}, 0.032 \mathrm{mmol})$ was added and the resultant mixture was degassed by vacuum/nitrogen cycling (x5) and stirred at room temperature for $18 \mathrm{~h}$. The mixture was partitioned between ethyl acetate and sat. aq. $\mathrm{Na}_{2} \mathrm{CO}_{3}$. The organic phase was dried $\left(\mathrm{MgSO}_{4}\right)$, filtered and concentrated in vacuo. The residue was purified by silica gel flash chromatography to give $\mathbf{5 7}$ (240 mg, 80\% purity, 59\%) as a white solid. LRMS found for $\mathrm{M}^{+}+1$, $519.2, \mathrm{C}_{36} \mathrm{H}_{31} \mathrm{~N}_{4}$ requires 519.3.

Step 4. 57 (240 mg, $0.46 \mathrm{mmol})$ was dissolved in DCM (10 mL) and cooled in an ice-bath. Triethylsilane $(2.5 \mathrm{~mL})$ was added followed by TFA $(2.5 \mathrm{~mL})$. The resulting mixture was stirred at $0{ }^{\circ} \mathrm{C}$ for $2 \mathrm{~h}$ and then concentrated in vacuo. The residue was partitioned between ethyl acetate and a sat. aq. $\mathrm{Na}_{2} \mathrm{CO}_{3}$. The organic phase was dried $\left(\mathrm{Na}_{2} \mathrm{SO}_{4}\right)$, filtered and concentrated in vacuo. The residue was purified by silica gel flash chromatography to give $4(92 \mathrm{mg}, 70 \%)$ as a white solid. ${ }^{1} \mathrm{H}$ NMR (400 MHz, DMSO- $\left.d_{6}\right) \delta 13.86(\mathrm{~s}, 1 \mathrm{H}), 8.61(\mathrm{~d}, J=4.8 \mathrm{~Hz}, 1 \mathrm{H}), 8.28(\mathrm{~d}, J=1.4 \mathrm{~Hz}$, 1H), 7.92 (q, $J=1.5 \mathrm{~Hz}, 1 \mathrm{H}), 7.86$ (ddd, $J=5.9,3.0,1.7 \mathrm{~Hz}, 1 \mathrm{H}), 7.80-7.59$ (m, 2H), 7.42 (d, $J=$ $4.8 \mathrm{~Hz}, 1 \mathrm{H}), 2.16-2.00(\mathrm{~m}, 2 \mathrm{H}), 1.77(\mathrm{~s}, 3 \mathrm{H}), 0.92(\mathrm{t}, J=7.3 \mathrm{~Hz}, 3 \mathrm{H})$. HRMS found for $\mathrm{M}^{+}+1$, 277.1453, $\mathrm{C}_{17} \mathrm{H}_{17} \mathrm{~N}_{4}$ requires 277.1448.

2-(3-(1H-Pyrazolo[3,4-b]pyridin-4-yl)phenyl)-2-methylbutan-1-amine trifluoroacetate (6). Step 1. To a solution of 4 (22 $\mathrm{mg}, 0.084 \mathrm{mmol})$ in THF $(3 \mathrm{~mL})$ was slowly added lithium aluminum hydride ( $2 \mathrm{M}$ in THF, $0.336 \mathrm{mmol}$ ). The reaction mixture was stirred at room temperature for $18 \mathrm{~h}$ and then water was carefully added followed by ethyl acetate. The organic phase was dried $\left(\mathrm{MgSO}_{4}\right)$, filtered and concentrated in vacuo. The residue was purified by reverse phase preparative HPLC [Waters Sunfire CI8, 10 iM, 100 A column, gradient 10\% - 95\% B (solvent A: $0.05 \%$ TFA in water; solvent $\mathrm{B}: \mathrm{CH}_{3} \mathrm{CN}$ ) over $16 \mathrm{~min}$ at $25 \mathrm{~mL} / \mathrm{min}$ ] and the fractions freeze-dried to give $6(12 \mathrm{mg}, 54 \%)$ as a white solid. ${ }^{1} \mathrm{H}$ NMR $\left(400 \mathrm{MHz}, \mathrm{DMSO}-d_{6}\right) \delta 13.90(\mathrm{br}$ $\mathrm{s}, 1 \mathrm{H}), 8.67(\mathrm{~d}, J=4.8 \mathrm{~Hz}, 1 \mathrm{H}), 8.37(\mathrm{~s}, 1 \mathrm{H}), 7.85(\mathrm{~s}, 1 \mathrm{H}), 7.83(\mathrm{~s}, 1 \mathrm{H}), 7.70-7.61(\mathrm{~m}, 2 \mathrm{H}), 7.53-$ $7.20(\mathrm{~m}, 4 \mathrm{H}), 3.34(\mathrm{~d}, J=13.2 \mathrm{~Hz}, 1 \mathrm{H}), 3.13(\mathrm{~d}, J=13.2 \mathrm{~Hz}, 1 \mathrm{H}), 1.98-1.89(\mathrm{~m}, 1 \mathrm{H}), 1.77-1.64$ $(\mathrm{m}, 1 \mathrm{H}), 1.48(\mathrm{~s}, 3 \mathrm{H}), 0.71(\mathrm{t}, J=7.2 \mathrm{~Hz}, 3 \mathrm{H})$. HRMS found for $\mathrm{M}^{+}+1,281.1760, \mathrm{C}_{17} \mathrm{H}_{21} \mathrm{~N}_{4}$ requires 281.1761 .

2-(3-(1H-Pyrazolo[3,4-b]pyridin-4-yl)phenyl)-2-methylpent-4-yn-1-amine (7). Step 1. A mixture of bis(pinacolato)diboron $(14.1 \mathrm{~g}, 55.4 \mathrm{mmol}), \mathrm{KOAc}(10.9 \mathrm{~g}, 111 \mathrm{mmol}), \mathbf{5 5}(8.17 \mathrm{~g}$, $37.0 \mathrm{mmol})$ and $\mathrm{PdCl}_{2}(\mathrm{dppf})_{2} . \mathrm{DCM}(1.51 \mathrm{~g}, 1.85 \mathrm{mmol})$ in DME $(120 \mathrm{~mL})$ was heated under reflux for $3.5 \mathrm{~h}$. After cooling to room temperature, the reaction was filtered through a pad of Celite, washing with ethyl acetate. The filtrate was concentrated under reduced presssure and the crude product was purified by column chromatography $\left(330 \mathrm{~g} \mathrm{SiO}_{2}, 0\right.$ to $20 \%$ ethyl acetate/petroleum ether) to give $63\left(9.18 \mathrm{~g}, 97 \%\right.$ ) as an orange oil. ${ }^{1} \mathrm{H}$ NMR (400 MHz, DMSO- 
$\left.d_{6}\right) \delta 7.69(\mathrm{~s}, 1 \mathrm{H}), 7.64(\mathrm{~d}, J=7.2 \mathrm{~Hz}, 1 \mathrm{H}), 7.56-7.52(\mathrm{~m}, 1 \mathrm{H}), 7.44(\mathrm{t}, J=7.6 \mathrm{~Hz}, 1 \mathrm{H}), 4.36(\mathrm{q}, J$ $=7.2 \mathrm{~Hz}, 1 \mathrm{H}), 1.53(\mathrm{~d}, J=7.2 \mathrm{~Hz}, 3 \mathrm{H}), 1.31(\mathrm{~s}, 2 \mathrm{H})$. LRMS found for $\mathrm{M}^{+}+1,258.1$, $\mathrm{C}_{15} \mathrm{H}_{21} \mathrm{BNO}_{2}$ requires 258.2 .

Step 2. A mixture of $\mathbf{6 3}(4.0 \mathrm{~g}, 12.6 \mathrm{mmol}), \mathbf{2 9}(6.14 \mathrm{~g}, 12.6 \mathrm{mmol})$ and $\mathrm{Na}_{2} \mathrm{CO}_{3}(2 \mathrm{M}, 37.8$ $\mathrm{mmol})$ in dioxane $\left(100 \mathrm{~mL}\right.$ ) was degassed (by vacuum/nitrogen cycling) five times. $\mathrm{Pd}\left[\mathrm{P}(\mathrm{tBu})_{3}\right]_{2}$ (322 $\mathrm{mg}, 0.630 \mathrm{mmol}$ ) was added, the reaction vessel similarly degassed three times and then heated and stirred at $60{ }^{\circ} \mathrm{C}$ for $3.5 \mathrm{~h}$. After cooling to room temperature, the reaction was diluted with ethyl acetate, washed with water, brine, dried $\left(\mathrm{MgSO}_{4}\right)$, filtered and concentrated under reduced pressure. The crude product was purified by column chromatography $\left(120 \mathrm{~g} \mathrm{SiO}_{2}, 0\right.$ to $40 \%$ ethyl acetate/petroleum ether) to give $64(5.5 \mathrm{~g}, 89 \%)$ as a cream foam. ${ }^{1} \mathrm{H}$ NMR (400 MHz, DMSO- $\left.d_{6}\right) \delta 8.73(\mathrm{~d}, J=4.4 \mathrm{~Hz}, 1 \mathrm{H}), 8.12(\mathrm{~s}, 1 \mathrm{H}), 7.76(\mathrm{~s}, 1 \mathrm{H}), 7.70(\mathrm{~d}, J=7.6 \mathrm{~Hz}, 1 \mathrm{H}), 7.58-$ $7.48(\mathrm{~m}, 2 \mathrm{H}), 7.43-7.32(\mathrm{~m}, 9 \mathrm{H}), 7.33(\mathrm{~d}, J=4.8 \mathrm{~Hz}, 1 \mathrm{H}), 7.20-7.11(\mathrm{~m}, 6 \mathrm{H}), 4.37(\mathrm{q}, J=7.2 \mathrm{~Hz}$, $1 \mathrm{H}), 1.52(\mathrm{~d}, J=7.2 \mathrm{~Hz}, 3 \mathrm{H})$. LRMS found for $\mathrm{M}^{+}+1,491.2, \mathrm{C}_{34} \mathrm{H}_{27} \mathrm{~N}_{4}$ requires 491.2.

Step 3. To a solution of $64(400 \mathrm{mg}, 0.815 \mathrm{mmol})$ in THF $(5 \mathrm{~mL})$ at $0{ }^{\circ} \mathrm{C}$ was added sodium hydride $(60 \%$ in mineral oil, $39.1 \mathrm{mg}, 0.978 \mathrm{mmol})$ in one portion. The mixture was stirred at 0 ${ }^{\circ} \mathrm{C}$ for $40 \mathrm{~min}$, then propargyl bromide $(97 \mathrm{mg}, 0.815 \mathrm{mmol}$ ) was added and the ice bath removed. After stirring for $1 \mathrm{~h}$ at RT, the mixture was quenched with water and diluted with ethyl acetate. The organic layer was collected and washed with water, brine, dried $\left(\mathrm{MgSO}_{4}\right)$, filtered and concentrated under reduced pressure. The crude product was purified by column chromatography (12 g, 0 to $35 \%$ ethyl acetate/petroleum ether) to give $\mathbf{6 5}(310 \mathrm{mg}, 61 \%, 85 \%$ pure) as an offwhite foam. ${ }^{1} \mathrm{H}$ NMR $\left(400 \mathrm{MHz}, \mathrm{DMSO}-d_{6}\right) \delta 8.75(\mathrm{~d}, J=4.8 \mathrm{~Hz}, 1 \mathrm{H}), 8.15(\mathrm{~s}, 1 \mathrm{H}), 7.86(\mathrm{~s}, 1 \mathrm{H})$, $7.74(\mathrm{~d}, J=7.6 \mathrm{~Hz}, 1 \mathrm{H}), 7.65(\mathrm{~d}, J=7.6 \mathrm{~Hz}, 1 \mathrm{H}), 7.59(\mathrm{t}, \mathrm{J}=7.6 \mathrm{~Hz}, 1 \mathrm{H}), 7.42-7.35(\mathrm{~m}, 1 \mathrm{H})$, 7.20-7.14 (m, 6H), 2.99-2.96 (m, 2H), $1.71(\mathrm{~s}, 3 \mathrm{H}), 1.07(\mathrm{~s}, 1 \mathrm{H})$. LRMS found for $\mathrm{M}^{+}+1,529.5$, $\mathrm{C}_{37} \mathrm{H}_{29} \mathrm{~N}_{4}$ requires 529.2.

Step 4. To a solution of $\mathbf{6 5}(310 \mathrm{mg}, 0.498 \mathrm{mmol})$ and water $(264 \mu \mathrm{L})$ in DCM $(10 \mathrm{~mL})$ and methanol $(1 \mathrm{~mL})$ at $0{ }^{\circ} \mathrm{C}$ was added TFA $(2.84 \mathrm{~g}, 24.9 \mathrm{mmol})$. The reaction mixture was stirred 0 ${ }^{\circ} \mathrm{C}$ for $1 \mathrm{~h}$ then allowed to warm to RT overnight. DCM was added and the mixture basified with saturated aq. $\mathrm{NaHCO}_{3}$ solution. The aqueous layer was extracted with a further portion of DCM and the combined organics washed with water, brine, dried $\left(\mathrm{MgSO}_{4}\right)$, filtered and concentrated under reduced pressure. Purification by column chromatography (12 g, 0 to $10 \% \mathrm{MeOH}$ in DCM) gave slightly impure product. Further purification by prep HPLC (aq. TFA/MeCN), basification of the pure fractions through a PS-bicarbonate cartridge and freeze-drying gave 66 ( $73 \mathrm{mg}, 51 \%$ ) as a white solid. ${ }^{1} \mathrm{H}$ NMR $\left(400 \mathrm{MHz}, \mathrm{DMSO}-d_{6}\right) \delta 13.86(\mathrm{br} \mathrm{s}, 1 \mathrm{H}), 8.62(\mathrm{~d}, J=4.8 \mathrm{~Hz}, 1 \mathrm{H}), 8.33$ (s, 1H), 7.99 (s, 1H), 7.88 (d, $J=7.2 \mathrm{~Hz}, 1 \mathrm{H}), 7.74-7.66(\mathrm{~m}, 2 \mathrm{H}), 7.42(\mathrm{~d}, J=4.8 \mathrm{~Hz}, 1 \mathrm{H}), 3.13-$ $3.09(\mathrm{~m}, 3 \mathrm{H}), 1.84(\mathrm{~s}, 3 \mathrm{H})$. LRMS found for $\mathrm{M}^{+}+1,287.1, \mathrm{C}_{18} \mathrm{H}_{15} \mathrm{~N}_{4}$ requires 286.1.

Step 5. To a solution of $66(70 \mathrm{mg}, 0.245 \mathrm{mmol})$ in THF $(5 \mathrm{~mL})$ was added $\mathrm{LiAlH}_{4}(2 \mathrm{M}, 1.47$ $\mathrm{mmol}$ ) and the reaction mixture stirred at room temperature for $5 \mathrm{~h}$ during which time, a yellow suspension formed. The reaction was quenched with water, diluted with ethyl acetate and the organic layer washed with water, brine, dried $\left(\mathrm{MgSO}_{4}\right)$, filtered and concentrated under reduced pressure. The crude product was purified by prep HPLC (aq. TFA/MeCN) and the pure fractions basified through a PS-bicarbonate cartridge and freeze-dried to give 7 (3 $\mathrm{mg}, 4 \%)$ as a white solid. ${ }^{1} \mathrm{H}$ NMR (400 MHz, DMSO- $\left.d_{6}\right) \delta 13.90(1 \mathrm{H}, \mathrm{br}, \mathrm{s}), 8.59-8.57(\mathrm{~m}, 1 \mathrm{H}), 8.33(\mathrm{~s}, 1 \mathrm{H}), 7.83$ $(\mathrm{s}, 1 \mathrm{H}), 7.70-7.69(\mathrm{~m}, 1 \mathrm{H}), 7.55-7.52(\mathrm{~m}, 2 \mathrm{H}), 7.38(\mathrm{~d}, J=4.8 \mathrm{~Hz}, 1 \mathrm{H}), 3.52-3.10(\mathrm{~m}, 2 \mathrm{H}), 2.88-$ $2.84(\mathrm{~m}, 1 \mathrm{H}), 2.79-2.73(\mathrm{~m}, 3 \mathrm{H}), 2.62-2.54(\mathrm{~m}, 1 \mathrm{H}), 1.42(\mathrm{~s}, 3 \mathrm{H})$. ESMS $m / z\left(\mathrm{M}^{+}+1\right) ; 291.14$. HRMS found for $\mathrm{M}^{+}+1,291.1603, \mathrm{C}_{18} \mathrm{H}_{19} \mathrm{~N}_{4}$ requires 291.1604 .

2-(3-(1H-Pyrazolo[3,4-b]pyridin-4-yl)phenyl)-2-methylpropan-1-amine (5).

This compound was prepared as described above for compound 7, starting from 3 ( $22 \mathrm{mg}, 0.084$ $\mathrm{mmol})$ to give the $5(12 \mathrm{mg}, 54 \%)$ as a white solid. ${ }^{1} \mathrm{H}$ NMR (400 MHz, DMSO- $\left.d_{6}\right) \delta 13.82(\mathrm{~s}$, $1 \mathrm{H}), 8.61(\mathrm{~d}, J=4.8 \mathrm{~Hz}, 1 \mathrm{H}), 8.33(\mathrm{~s}, 1 \mathrm{H}), 7.85(\mathrm{~s}, 1 \mathrm{H}), 7.78(\mathrm{dt}, J=5.4,1.9 \mathrm{~Hz}, 1 \mathrm{H}), 7.70(\mathrm{~s}$, 
3H), $7.62(\mathrm{~d}, J=5.1 \mathrm{~Hz}, 2 \mathrm{H}), 7.41(\mathrm{~d}, J=4.8 \mathrm{~Hz}, 1 \mathrm{H}), 3.19$ (q, $J=5.7 \mathrm{~Hz}, 1 \mathrm{H}), 1.44(\mathrm{~s}, 6 \mathrm{H})$. ESMS $m / z\left(\mathrm{M}^{+}+1\right) ; 267.15$. HRMS found for $\mathrm{M}^{+}+1,267.1610, \mathrm{C}_{16} \mathrm{H}_{19} \mathrm{~N}_{4}$ requires 267.1604.

(1-(3-(1H-Pyrazolo[3,4-b]pyridin-4-yl)phenyl)cyclobutyl)methanamine trifluoroacetate (8) Step 1. To a solution of 2-(3-bromophenyl)acetonitrile (5.82 g, $29.7 \mathrm{mmol})$ in DMSO $(80 \mathrm{~mL})$ at room temperature, was added portionwise sodium hydride $(60 \% \mathrm{w} / \mathrm{w}$ in mineral oil, $2.61 \mathrm{~g}, 65.3$ $\mathrm{mmol})$. After $30 \mathrm{~min}$, the reaction mixture was cooled to $0{ }^{\circ} \mathrm{C}$, treated with 1,3-dibromopropane $(6.29 \mathrm{~g}, 31.2 \mathrm{mmol})$ and allowed to warm to room temperature over an hour. Water was carefully added and the mixture extracted with ethyl acetate/toluene $(2: 1)$. The organics were combined, washed with $2 \mathrm{M} \mathrm{HCl}$, water, brine then dried $\left(\mathrm{MgSO}_{4}\right)$, filtered and concentrated. Purification by column chromatography (120 g, ethyl acetate/heptane $0-20 \%)$ gave $\mathbf{3 8}(4.11 \mathrm{~g}, 59 \%)$ as a colorless oil. ${ }^{1} \mathrm{H}$ NMR $\left(400 \mathrm{MHz}, \mathrm{CDCl}_{3}\right) \delta 7.57(\mathrm{t}, J=1.9 \mathrm{~Hz}, 1 \mathrm{H}), 7.48$ (ddd, $J=7.8,1.9,1.1$ $\mathrm{Hz}, 1 \mathrm{H}), 7.37$ (ddd, $J=7.8,1.9,1.1 \mathrm{~Hz}, 1 \mathrm{H}), 7.33$ - $7.26(\mathrm{~m}, 1 \mathrm{H}), 2.91-2.79$ (m, 2H), 2.70 - 2.57 $(\mathrm{m}, 2 \mathrm{H}), 2.54-2.40(\mathrm{~m}, 1 \mathrm{H}), 2.18-2.04(\mathrm{~m}, 1 \mathrm{H})$.

Step 2. A solution of $\mathbf{3 0}(150 \mathrm{mg}, 0.308 \mathrm{mmol}), \mathbf{3 8}(72.7 \mathrm{mg}, 0.308 \mathrm{mmol})$ and $\mathrm{Na}_{2} \mathrm{CO}_{3}(2 \mathrm{M}$, $0.923 \mathrm{mmol})$ in dioxane $(4 \mathrm{~mL})$ was degassed and flushed with nitrogen 5 times before $\operatorname{Pd}\left[\mathrm{P}\left({ }^{\mathrm{t}} \mathrm{Bu}\right)_{3}\right]_{2}(7.8 \mathrm{mg}, 0.0154 \mathrm{mmol})$ was added. The solution was again flushed with nitrogen 3 times and then heated at $60^{\circ} \mathrm{C}$ for $1 \mathrm{~h}$. The reaction was cooled to RT, partitioned between ethyl acetate and water. The organic layer was separated and washed with water, brine, dried $\left(\mathrm{MgSO}_{4}\right)$, filtered and concentrated in vacuo. The crude product was purified by column chromatography (12 g, $0-15 \%$ ethyl acetate/petroleum ether) to give $\mathbf{4 2}(130 \mathrm{mg}, 82 \%)$ as a colorless oil. ${ }^{1} \mathrm{H}$ NMR $\left(400 \mathrm{MHz}, \mathrm{CDCl}_{3}\right) \delta 8.33(\mathrm{~d}, J=4.8 \mathrm{~Hz}, 1 \mathrm{H}), 8.26(\mathrm{~s}, 1 \mathrm{H}), 7.79-7.56(\mathrm{~m}, 4 \mathrm{H}), 7.31-7.25(\mathrm{~m}, 5 \mathrm{H})$, $7.13(\mathrm{~d}, J=4.8 \mathrm{~Hz}, 1 \mathrm{H}), 2.90-2.83(\mathrm{~m}, 2 \mathrm{H}), 2.72-2.65(\mathrm{~m}, 2 \mathrm{H}), 2.54-2.41(\mathrm{~m}, 1 \mathrm{H}), 2.16-2.08(\mathrm{~m}$, $1 \mathrm{H})$; LRMS found for $\mathrm{M}^{+}+1,517.2, \mathrm{C}_{36} \mathrm{H}_{29} \mathrm{~N}_{4}$ requires 517.2.

Step 3. To a solution of $42(130 \mathrm{mg}, 0.252 \mathrm{mmol})$ in DCM $(3 \mathrm{~mL})$ at $0{ }^{\circ} \mathrm{C}$ was added triethylsilane $(117 \mathrm{mg}, 1.01 \mathrm{mmol})$ followed by TFA $(400 \mu \mathrm{L})$ and the mixture stirred at $0{ }^{\circ} \mathrm{C}$ for $1 \mathrm{~h}$. The mixture was diluted with DCM $(30 \mathrm{~mL})$ and basified with saturated aqueous $\mathrm{NaHCO}_{3}$ solution. The organics were washed with brine, dried $\left(\mathrm{MgSO}_{4}\right)$, filtered and concentrated in vacuo. The crude product was purified by Fractionlynx preparatory LCMS and the pure fraction passed through a SPE bicarbonate cartridge and freeze-dried to leave $44(41 \mathrm{mg}, 59 \%)$ as a white solid. ${ }^{1} \mathrm{H}$ NMR (400 MHz, DMSO- $\left.d_{6}\right) \delta 13.85$ (br s, $\left.1 \mathrm{H}\right), 8.61(\mathrm{~d}, J=4.8 \mathrm{~Hz}, 1 \mathrm{H}), 8.31(\mathrm{~s}, 1 \mathrm{H})$, $7.88-7.86(\mathrm{~m}, 2 \mathrm{H}), 7.70-7.63(\mathrm{~m}, 2 \mathrm{H}), 7.43(\mathrm{~d}, J=4.8 \mathrm{~Hz}, 1 \mathrm{H}), 2.82-2.75(\mathrm{~m}, 4 \mathrm{H}), 2.36-2.29$ $(\mathrm{m}, 1 \mathrm{H}), 2.08-2.04(\mathrm{~m}, 1 \mathrm{H})$. LRMS found for $\mathrm{M}^{+}+1,275.2, \mathrm{C}_{17} \mathrm{H}_{15} \mathrm{~N}_{4}$ requires 275.1 .

Step 4. To a solution of 44 (36 mg, $0.129 \mathrm{mmol})$ in THF (4 mL) was added $\mathrm{LiAlH}_{4}(2 \mathrm{M}, 0.516$ $\mathrm{mmol})$ at room temperature. After overnight stirring, additional $\mathrm{LiAlH}_{4}(2 \mathrm{M}, 0.516 \mathrm{mmol})$ was added and stirring continued at room temperature for $2.5 \mathrm{~h}$. The reaction was quenched with water and extracted with ethyl acetate twice. The organics were combined, washed with brine, dried $\left(\mathrm{MgSO}_{4}\right)$, filtered and concentrated in vacuo. The crude product was purified by Fractionlynx prep LCMS and lyophilized to give $8(6 \mathrm{mg}, 11 \%)$ as a white solid. ${ }^{1} \mathrm{H}$ NMR (400 MHz, DMSO- $\left.d_{6}\right) \delta 13.82(\mathrm{br} \mathrm{s}, 1 \mathrm{H}), 8.61-8.58(\mathrm{~d}, J=4.8 \mathrm{~Hz}, 1 \mathrm{H}), 8.35(\mathrm{~s}, 1 \mathrm{H}), 7.78(\mathrm{~d}, J=7.6$ $\mathrm{Hz}, 1 \mathrm{H}), 7.69-7.60$ (m, 5H), 7.42 - 7.38 (m, 2H), 3.32 (d, J=5.2 Hz, 2H), $2.43-2.36(\mathrm{~m}, 4 \mathrm{H})$, 2.19 - $2.08(\mathrm{~m}, 1 \mathrm{H}), 1.88-1.80(\mathrm{~m}, 1 \mathrm{H})$; LRMS found for $\mathrm{M}^{+}+1,279.2, \mathrm{C}_{17} \mathrm{H}_{19} \mathrm{~N}_{4}$ requires 279.2 .

(1-(3-(1H-Pyrazolo[3,4-b]pyridin-4-yl)phenyl)cyclopentyl)methanamine (9). Step 1. NaH $(60 \% \mathrm{w} / \mathrm{w}$ in mineral oil, $1.35 \mathrm{~g}, 33.7 \mathrm{mmol})$ was added portionwise over $10 \mathrm{~min}$ to a solution of 3-bromophenylacetonitrile $(3 \mathrm{~g}, 15.3 \mathrm{mmol})$ in DMSO $(24 \mathrm{~mL})$ at room temperature. After 40 min, 1,4-dibromobutane $(3.47 \mathrm{~g}, 16.1 \mathrm{mmol})$ was slowly added with ice-bath cooling and the resulting mixture stirred for $1 \mathrm{~h}$. Water was added and the mixture extracted twice with ethyl 
acetate/toluene (2:1). The organics were washed with $2 \mathrm{M} \mathrm{HCl}$, water, brine, dried $\left(\mathrm{MgSO}_{4}\right)$, filtered and concentrated in vacuo. The crude product was purified by column chromatography (120 g, 0 - 5\% ethyl acetate/petroleum ether) to give $39(2.59 \mathrm{~g}, 68 \%)$ as a colorless oil. ${ }^{1} \mathrm{H}$ NMR $\left(400 \mathrm{MHz}, \mathrm{DMSO}-d_{6}\right) \delta 7.69(\mathrm{t}, J=1.9 \mathrm{~Hz}, 1 \mathrm{H}), 7.63-7.51(\mathrm{~m}, 2 \mathrm{H}), 7.40(\mathrm{t}, J=8.0 \mathrm{~Hz}, 1 \mathrm{H})$, $2.43(\mathrm{dq}, J=12.1,3.4 \mathrm{~Hz}, 2 \mathrm{H}), 2.16-2.02(\mathrm{~m}, 2 \mathrm{H}), 1.96-1.80(\mathrm{~m}, 4 \mathrm{H})$.

Step 2. A solution of $\mathbf{3 0}$ (150 mg, $0.308 \mathrm{mmol}), 39(77 \mathrm{mg}, 0.308 \mathrm{mmol})$ and $\mathrm{Na}_{2} \mathrm{CO}_{3}(2 \mathrm{M}, 0.923$ $\mathrm{mmol})$ in dioxane $(4 \mathrm{~mL})$ was degassed and flushed with nitrogen 5 times and then $\mathrm{Pd}\left[\mathrm{P}(\mathrm{tBu})_{3}\right]_{2}$ (7.9 $\mathrm{mg}, 0.0154 \mathrm{mmol}$ ) was added. The solution was again flushed with nitrogen 3 times and then heated at $60{ }^{\circ} \mathrm{C}$ for $1 \mathrm{~h}$. The reaction mixture was cooled to room temperature and partitioned between ethyl acetate and water. The organic layer was separated, washed with water, brine, dried $\left(\mathrm{MgSO}_{4}\right)$, filtered and concentrated in vacuo. The crude product was purified by column chromatography (12 g, 0-15\% ethyl acetate/petroleum ether) to give $43(144 \mathrm{mg}, 88 \%$ ) as a colorless oil. ${ }^{1} \mathrm{H}$ NMR $\left(400 \mathrm{MHz}, \mathrm{CDCl}_{3}\right) \delta 8.31(\mathrm{~d}, J=4.4 \mathrm{~Hz}, 1 \mathrm{H}), 8.23(\mathrm{~s}, 1 \mathrm{H}), 7.82(\mathrm{~s}, 1 \mathrm{H})$, 7.69-7.55 (m, 3H), 7.29-7.25 (m, 5H), 7.12 (d, $J=4.8 \mathrm{~Hz}, 1 \mathrm{H}), 2.59-2.54(\mathrm{~m}, 2 \mathrm{H}), 2.20-1.97$ (m, $6 \mathrm{H})$. LRMS found for $\mathrm{M}^{+}+1,531.2, \mathrm{C}_{37} \mathrm{H}_{31} \mathrm{~N}_{4}$ requires 531.3.

Step 3. To a solution of $\mathbf{4 3}(144 \mathrm{mg}, 0.2714 \mathrm{mmol})$ in DCM $(3 \mathrm{~mL})$ at $0{ }^{\circ} \mathrm{C}$ was added triethylsilane $(126 \mathrm{mg}, 1.09 \mathrm{mmol})$ followed by TFA $(0.4 \mathrm{~mL})$. The reaction was stirred at $0{ }^{\circ} \mathrm{C}$ for $1 \mathrm{~h}$. DCM $(30 \mathrm{~mL})$ and sat. aq. $\mathrm{NaHCO}_{3}$ solution were added and the organics collected, washed with brine, dried $\left(\mathrm{MgSO}_{4}\right)$, filtered and concentrated in vacuo. The crude product was purified by Fractionlynx prep LCMS and the fractions freeze-dried to leave $\mathbf{4 5}$ (31 $\mathrm{mg}, 39 \%$ ) as a white solid. ${ }^{1} \mathrm{H}$ NMR $\left(400 \mathrm{MHz}, \mathrm{DMSO}-d_{6}\right) \delta 13.85(\mathrm{br} \mathrm{s}, 1 \mathrm{H}), 8.61(\mathrm{~d}, J=4.8 \mathrm{~Hz}, 1 \mathrm{H}), 8.30$ (s, 1H), 7.93 (s, 1H), 7.87 - 7.85 (m, 1H), 7.69 - 7.66 (m, 2H), 7.42 (d, $J=4.4 \mathrm{~Hz}, 1 \mathrm{H}), 2.51-2.48$ $(\mathrm{m}, 2 \mathrm{H}), 2.23-2.18(\mathrm{~m}, 2 \mathrm{H}), 1.95-1.93(\mathrm{~m}, 4 \mathrm{H})$. LRMS found for $\mathrm{M}^{+}+1,289.2, \mathrm{C}_{18} \mathrm{H}_{16} \mathrm{~N}_{4}$ requires 289.2 .

Step 4. To a solution of 45 (33 mg, $0.112 \mathrm{mmol})$ in THF (4 mL) was added $\mathrm{LiAlH}_{4}(2 \mathrm{M}, 0.449$ $\mathrm{mmol})$ at room temperature and the reaction mixture stirred overnight. The reaction was quenched with water and extracted twice with ethyl acetate. The combined organics were washed with brine, dried $\left(\mathrm{MgSO}_{4}\right)$, filtered and concentrated in vacuo. The crude product was purified by Fractionlynx prep LCMS (MeCN/aq. TFA) and freeze-dried to leave $9(5 \mathrm{mg}, 11 \%)$ as a white solid. ${ }^{1} \mathrm{H}$ NMR (400 MHz, DMSO- $\left.d_{6}\right) \delta 13.83($ br s, $1 \mathrm{H}), 8.61(\mathrm{~d}, J=4.8 \mathrm{~Hz}, 1 \mathrm{H}), 8.34(\mathrm{~s}, 1 \mathrm{H})$, $7.79(\mathrm{~d}, J=8.0 \mathrm{~Hz}, 2 \mathrm{H}), 7.63-7.55(\mathrm{~m}, 4 \mathrm{H}), 7.42(\mathrm{~d}, J=4.8 \mathrm{~Hz}, 1 \mathrm{H}), 3.15-3.13(\mathrm{~d}, J=5.6 \mathrm{~Hz}$, $2 \mathrm{H}), 2.09-1.98(\mathrm{~m}, 4 \mathrm{H}), 1.77-1.66(\mathrm{~m}, 4 \mathrm{H})$; LRMS found for $\mathrm{M}^{+}+1,293.2, \mathrm{C}_{18} \mathrm{H}_{21} \mathrm{~N}_{4}$ requires 293.2.

(1-(3-(1H-Pyrazolo[3,4-b]pyridin-4-yl)phenyl)cyclohexyl)methanamine (10). Step 1. To a solution of 3-bromophenylacetonitrile (3 g, $15.3 \mathrm{mmol})$ in DMSO $(24 \mathrm{~mL})$ was added $\mathrm{NaH}(60 \%$ $\mathrm{w} / \mathrm{w}$ in mineral oil, $1.35 \mathrm{~g}, 33.7 \mathrm{mmol}$ ) portionwise over $10 \mathrm{~min}$ at room temperature. After stirring for $40 \mathrm{~min}$, 1,5-dibromopentane $(3.70 \mathrm{~g}, 16.1 \mathrm{mmol})$ was added dropwise with ice bath cooling and the mixture stirred at room temperature for $1 \mathrm{~h}$. Water was added and the mixture extracted twice with ethyl acetate/toluene (2:1). The organics were washed with $2 \mathrm{M} \mathrm{HCl}$, water, brine, dried $\left(\mathrm{MgSO}_{4}\right)$, filtered and concentrated in vacuo. The crude product was purified by column chromatography (120 g, 0 - 5\% ethyl acetate/petroleum ether) to give $\mathbf{4 0}(2.33 \mathrm{~g}, 58 \%)$ as an opaque oil. ${ }^{1} \mathrm{H}$ NMR $\left(400 \mathrm{MHz}, \mathrm{DMSO}-d_{6}\right) \delta 7.71(\mathrm{t}, J=1.9 \mathrm{~Hz}, 1 \mathrm{H}), 7.64-7.50(\mathrm{~m}, 2 \mathrm{H})$, $7.41(\mathrm{t}, J=7.9 \mathrm{~Hz}, 1 \mathrm{H}), 2.06(\mathrm{~d}, J=12.9 \mathrm{~Hz}, 2 \mathrm{H}), 1.98-1.79(\mathrm{~m}, 4 \mathrm{H}), 1.73(\mathrm{~d}, J=13.2 \mathrm{~Hz}, 1 \mathrm{H})$, 1.61 (qt, $J=13.4,3.7 \mathrm{~Hz}, 2 \mathrm{H}), 1.44-1.21(\mathrm{~m}, 1 \mathrm{H})$.

Step 2. A mixture of $28(250 \mathrm{mg}, 0.513 \mathrm{mmol}), \mathbf{4 0}(149 \mathrm{mg}, 0.564 \mathrm{mmol})$ and sodium carbonate $(2 \mathrm{M}, 1.54 \mathrm{mmol})$ in 1,4-dioxane $(9 \mathrm{~mL})$ was degassed by vacuum/nitrogen cycles five times before $\mathrm{Pd}\left[\mathrm{P}(\mathrm{tBu})_{3}\right]_{2}(13.1 \mathrm{mg}, 25.6 \mu \mathrm{mol})$ was added. The reaction vessel was again subjected to vacuum/nitrogen cycles three times and heated at $60^{\circ} \mathrm{C}$ for $2 \mathrm{~h}$ under nitrogen. The reaction mixture was cooled to room temperature, diluted with ethyl acetate, washed with water, brine, 
dried $\left(\mathrm{MgSO}_{4}\right)$, filtered and concentrated in vacuo. Purification by column chromatography $(12 \mathrm{~g}$, $0-10 \%$ ethyl acetate/petroleum ether) gave $46(207 \mathrm{mg}, 74 \%)$ as a white foam. ${ }^{1} \mathrm{H}$ NMR (400 MHz, DMSO- $\left.d_{6}\right) \delta 8.39(\mathrm{~s}, 1 \mathrm{H}), 8.32(\mathrm{~d}, J=4.8 \mathrm{~Hz}, 1 \mathrm{H}), 7.93(\mathrm{~s}, 1 \mathrm{H}), 7.82(\mathrm{~d}, J=7.6 \mathrm{~Hz}, 1 \mathrm{H})$, 7.74-7.70 (m, 1H), $7.66(\mathrm{t}, J=7.6 \mathrm{~Hz}, 1 \mathrm{H}), 7.35-7.20(\mathrm{~m}, 6 \mathrm{H}), 2.20-2.13(\mathrm{~m}, 2 \mathrm{H}), 2.02-1.60(\mathrm{~m}$, $6 \mathrm{H}), 1.40-1.28(\mathrm{~m}, 2 \mathrm{H})$. LRMS found for $\mathrm{M}^{+}+1,545.4, \mathrm{C}_{37} \mathrm{H}_{33} \mathrm{~N}_{4}$ requires 545.3.

Step 3. To a solution of $\mathbf{4 6}(263 \mathrm{mg}, 0.381 \mathrm{mmol})$ in THF $(4 \mathrm{~mL})$ at $0{ }^{\circ} \mathrm{C}$ was slowly added alane$\mathrm{N}, \mathrm{N}$-dimethylethylamine $(0.5 \mathrm{M}$ in toluene, $1.14 \mathrm{mmol})$. The mixture was stirred at this temperature for $1 \mathrm{~h}$ then at room temperature overnight. The reaction was quenched by the addition of THF/water $(1: 1,4 \mathrm{~mL})$, stirred rapidly for 5 min then filtered through Celite, washing with copious amounts of ethyl acetate. The filtrate was dried $\left(\mathrm{MgSO}_{4}\right)$, filtered and concentrated in vacuo. The crude product was purified by column chromatography (12 g, 0-100\% ethyl acetate/petroleum ether) to leave $\mathbf{4 8}(188 \mathrm{mg}, 90 \%)$ as a white foam. ${ }^{1} \mathrm{H}$ NMR (400 MHz, DMSO- $\left.d_{6}\right) \delta 8.36(\mathrm{~s}, 1 \mathrm{H}), 8.29(\mathrm{~d}, J=4.8 \mathrm{~Hz}, 1 \mathrm{H}), 7.76(\mathrm{~s}, 1 \mathrm{H}), 7.57(\mathrm{~d}, J=7.2 \mathrm{~Hz}, 1 \mathrm{H}), 7.66-$ $7.50(\mathrm{~m}, 2 \mathrm{H}), 7.33-7.19(\mathrm{~m}, 6 \mathrm{H}), 2.60(\mathrm{~s}, 2 \mathrm{H}), 2.21-2.12(\mathrm{~m}, 2 \mathrm{H}), 1.62-1.20(\mathrm{~m}, 10 \mathrm{H})$. LRMS found for $\mathrm{M}^{+}+1,549.4, \mathrm{C}_{38} \mathrm{H}_{37} \mathrm{~N}_{4}$ requires 549.3.

Step 4. To a solution of $\mathbf{4 8}(188 \mathrm{mg}, 0.343 \mathrm{mmol})$ and triethylsilane $(159 \mathrm{mg}, 1.37 \mathrm{mmol})$ in DCM $(4 \mathrm{~mL})$ at $0{ }^{\circ} \mathrm{C}$ was added TFA $(781 \mathrm{mg}, 6.85 \mathrm{mmol})$ and the mixture stirred $0{ }^{\circ} \mathrm{C}$ for 30 min. The reaction mixture was concentrated in vacuo, slurried in $\mathrm{MeOH}$ and the trityl solid impurity removed by filtration. The filtrate was purified by Fractionlynx prep LCMS and TFA was removed by passing the fractions through a SPE-bicarbonate cartridge. Lyophilization gave 10 (59 mg, 54\%) as a white solid. ${ }^{1} \mathrm{H}$ NMR (400 MHz, DMSO- $\left.d_{6}\right) \delta 8.59-8.56(\mathrm{~m}, 1 \mathrm{H}), 8.29-8.26$ $(\mathrm{m}, 1 \mathrm{H}), 7.77(\mathrm{~s}, 1 \mathrm{H}), 7.67(\mathrm{~m}, 1 \mathrm{H}), 7.60-7.49(\mathrm{~m}, 2 \mathrm{H}), 7.39-7.36(\mathrm{~m}, 1 \mathrm{H}), 3.12-3.08(\mathrm{~m}, 2 \mathrm{H})$, $2.60(\mathrm{~s}, 2 \mathrm{H}), 2.20-2.11(\mathrm{~m}, 2 \mathrm{H}), 1.65-1.19(\mathrm{~m}, 8 \mathrm{H})$. HRMS found for $\mathrm{M}^{+}+1,307.1914, \mathrm{C}_{19} \mathrm{H}_{23} \mathrm{~N}_{4}$ requires 307.1917 .

(4-(3-(1H-Pyrazolo[3,4-b]pyridin-4-yl)phenyl)tetrahydro-2H-pyran-4-yl)methanamine (11). Step 1. To a solution of 3-bromophenylacetonitrile $(1 \mathrm{~g}, 5.10 \mathrm{mmol})$ in DMSO $(8 \mathrm{~mL})$ was added $\mathrm{NaH}(60 \% \mathrm{w} / \mathrm{w}$ in mineral oil, $449 \mathrm{mg}, 11.2 \mathrm{mmol})$ portionwise over $10 \mathrm{~min}$ at room temperature. After stirring for $40 \mathrm{~min}$, bis(2-chloroethyl)ether $(767 \mathrm{mg}, 5.36 \mathrm{mmol}$ ) was added dropwise and the mixture stirred at room temperature for $1 \mathrm{~h}$. Water was added and the mixture extracted twice with ethyl acetate/toluene $(2: 1)$. The organics were washed with $2 \mathrm{M} \mathrm{HCl}$, water, brine, dried $\left(\mathrm{MgSO}_{4}\right)$, filtered and concentrated in vacuo. The crude product was purified by column chromatography (40 g, 0 - 30\% ethyl acetate/petroleum ether) to give 41 (928 $\mathrm{mg}, 68 \%$ ) as a yellow solid. ${ }^{1} \mathrm{H}$ NMR $\left(400 \mathrm{MHz}, \mathrm{DMSO}-d_{6}\right) \delta 7.74(\mathrm{t}, J=1.9 \mathrm{~Hz}, 1 \mathrm{H}), 7.64-7.56(\mathrm{~m}, 2 \mathrm{H}), 7.43$ (t, $J=7.9 \mathrm{~Hz}, 1 \mathrm{H}), 4.09-3.93(\mathrm{~m}, 2 \mathrm{H}), 3.65(\mathrm{td}, J=11.9,2.4 \mathrm{~Hz}, 2 \mathrm{H}), 2.23-1.99(\mathrm{~m}, 4 \mathrm{H})$. Step 2. A mixture of $\mathbf{2 8}(250 \mathrm{mg}, 0.487 \mathrm{mmol}), 41(130 \mathrm{mg}, 0.487 \mathrm{mmol})$ and sodium carbonate $(2 \mathrm{M}, 1.46 \mathrm{mmol})$ in 1,4-dioxane $(5 \mathrm{~mL})$ was degassed and flushed with nitrogen five times before $\operatorname{Pd}\left[\mathrm{P}(\mathrm{tBu})_{3}\right]_{2}(12.5 \mathrm{mg}, 24.4 \mu \mathrm{mol})$ was added. The reaction vessel was again flushed with nitrogen three times before the mixture was heated at $60^{\circ} \mathrm{C}$ for $1 \mathrm{~h}$. After cooling to room temperature, ethyl acetate was added and the organic layer washed with water, brine, dried $\left(\mathrm{MgSO}_{4}\right)$, filtered and concentrated in vacuo . The crude product was purified by column chromatography (12 g, $0-20 \%$ ethyl acetate/petroleum ether) to leave $47(208 \mathrm{mg}, 78 \%)$ as a colourless oil. ${ }^{1} \mathrm{H}$ NMR $\left(400 \mathrm{MHz}, \mathrm{DMSO}-d_{6}\right) \delta 8.40(\mathrm{~s}, 1 \mathrm{H}), 8.32(\mathrm{~d}, J=4.8 \mathrm{~Hz}, 1 \mathrm{H}), 7.95(\mathrm{~s}$, $1 \mathrm{H}), 7.87-7.83(\mathrm{~m}, 1 \mathrm{H}), 7.75-7.64(\mathrm{~m}, 2 \mathrm{H}), 7.36(\mathrm{~d}, J=4.4 \mathrm{~Hz}, 1 \mathrm{H}), 7.30-7.16(\mathrm{~m}, 15 \mathrm{H}), 4.07-$ $3.98(\mathrm{~m}, 4 \mathrm{H}), 2.24-2.18(\mathrm{~m}, 4 \mathrm{H})$; LRMS found for $\mathrm{M}^{+}+1,547.5, \mathrm{C}_{37} \mathrm{H}_{31} \mathrm{~N}_{4} \mathrm{O}$ requires 546.2. Step 3. To a solution of $47(208 \mathrm{mg}, 0.381 \mathrm{mmol})$ in THF $(5 \mathrm{~mL})$ at $0{ }^{\circ} \mathrm{C}$ was carefully added alane-N,N-dimethylethylamine complex $(0.5 \mathrm{M}$ in toluene, $0.761 \mathrm{mmol})$ over a 5 minute period. The mixture was stirred at $0{ }^{\circ} \mathrm{C}$ for $1 \mathrm{~h}$, the ice-bath removed and additional alane-N,Ndimethylethylamine complex $(0.5 \mathrm{M}$ in toluene, $0.761 \mathrm{mmol})$ added and the reaction mixture stirred at room temperature overnight. The reaction was carefully quenched by the addition of 
THF/Water (1:1, $4 \mathrm{~mL})$, stirred rapidly for $5 \mathrm{~min}$, filtered through a pad of Celite and washed with copious amounts of ethyl acetate. The filtrate was washed with brine, dried $\left(\mathrm{MgSO}_{4}\right)$, filtered and concentrated in vacuo. The crude product was purified by column chromatography (12g, 0 - 5\% MeOH/DCM) to leave $49(121 \mathrm{mg}, 58 \%)$ as a white foam. ${ }^{1} \mathrm{H}$ NMR (400 MHz, DMSO- $\left.d_{6}\right) \delta 8.37(\mathrm{~s}, 1 \mathrm{H}), 8.29(\mathrm{~d}, J=4.4 \mathrm{~Hz}, 1 \mathrm{H}), 7.74(\mathrm{~s}, 1 \mathrm{H}), 7.68(\mathrm{~d}, J=7.6 \mathrm{~Hz}, 1 \mathrm{H}), 7.57(\mathrm{t}$, $J=7.6 \mathrm{~Hz}, 1 \mathrm{H}), 7.51(\mathrm{~d}, J=8.4 \mathrm{~Hz}, 1 \mathrm{H}), 7.32-7.20(\mathrm{~m}, 6 \mathrm{H}), 3.72-3.68(\mathrm{~m}, 2 \mathrm{H}), 3.43(\mathrm{t}, J=8.4$ $\mathrm{Hz}, 2 \mathrm{H}), 2.72(\mathrm{~s}, 2 \mathrm{H}), 2.12-2.08(\mathrm{~m}, 2 \mathrm{H}), 1.89-1.84(\mathrm{~m}, 2 \mathrm{H})$; LRMS found for $\mathrm{M}^{+}+1,551.5$, $\mathrm{C}_{37} \mathrm{H}_{35} \mathrm{~N}_{4} \mathrm{O}$ requires 551.3.

Step 4. To a solution of 49 (121 mg, $0.220 \mathrm{mmol})$ and triethylsilane $(102 \mathrm{mg}, 0.879 \mathrm{mmol})$ in DCM $(3 \mathrm{~mL})$ at $0{ }^{\circ} \mathrm{C}$ was added TFA $(501 \mathrm{mg}, 4.39 \mathrm{mmol})$ and the mixture stirred at $0{ }^{\circ} \mathrm{C}$ for 30 min. The reaction was concentrated in vacuo and purified by Fractionlynx prep LCMS. TFA was removed by passing the fractions through a SPE-bicarbonate cartridge and freeze-drying (from $\left.\mathrm{MeCN} / \mathrm{H}_{2} \mathrm{O}\right)$ gave $11(54 \mathrm{mg}, 78 \%)$ as a white solid. ${ }^{1} \mathrm{H}$ NMR (400 MHz, DMSO- $\left.d_{6}\right) \delta 13.79(\mathrm{br}$ $\mathrm{s}, 1 \mathrm{H}), 8.58(\mathrm{~d}, J=4.8 \mathrm{~Hz}, 1 \mathrm{H}), 8.27(\mathrm{~s}, 1 \mathrm{H}), 7.76-7.69(\mathrm{~m}, 2 \mathrm{H}), 7.60-7.56(\mathrm{~m}, 1 \mathrm{H}), 7.52-7.50$ $(\mathrm{d}, J=7.6 \mathrm{~Hz}, 1 \mathrm{H}), 7.39(\mathrm{~d}, J=4.8 \mathrm{~Hz}, 1 \mathrm{H}), 3.74-3.69(\mathrm{~m}, 2 \mathrm{H}), 3.48-3.25(\mathrm{~m}, 4 \mathrm{H}), 2.74(\mathrm{~s}, 2 \mathrm{H})$, 2.15-2.09 (m, 2H), $1.91-1.85(\mathrm{~m}, 2 \mathrm{H})$; HRMS found for $\mathrm{M}^{+}+1,309.1710, \mathrm{C}_{18} \mathrm{H}_{21} \mathrm{~N}_{4} \mathrm{O}$ requires 309.1710 .

2-Methyl-2-(3-methyl-5-(1H-pyrazolo[3,4-b]pyridin-4-yl)phenyl)butan-1-amine (12). Step 1. A solution of 1-bromo-3-(bromomethyl)-5-methylbenzene $(9.76 \mathrm{~g}, 37.0 \mathrm{mmol})$ in a mixture of DMF $(40 \mathrm{~mL})$ and water $(20 \mathrm{~mL})$ was treated with sodium cyanide $(1.99 \mathrm{~g}, 40.7 \mathrm{mmol})$ and the reaction mixture heated at $100{ }^{\circ} \mathrm{C}$ for $4 \mathrm{~h}$. After cooling to room temperature, water and ethyl acetate were added, organics further washed with water, brine, dried $\left(\mathrm{MgSO}_{4}\right)$, filtered and concentrated to give an oil. Purification by column chromatography (330 g, 1:1 DCM/petroleum ether) gave $82(5.89 \mathrm{~g}, 76 \%)$ as a colorless oil. ${ }^{1} \mathrm{H}$ NMR (400 MHz, $\left.\mathrm{CDCl}_{3}\right) \delta 7.32-7.28(\mathrm{~m}, 2 \mathrm{H})$, $7.10(\mathrm{~s}, 1 \mathrm{H}), 3.71(\mathrm{~s}, 2 \mathrm{H}), 2.36(\mathrm{~s}, 3 \mathrm{H})$.

Step 2. To a solution of $82(3.69 \mathrm{~g}, 17.6 \mathrm{mmol})$ in THF $(46 \mathrm{~mL})$ at $0{ }^{\circ} \mathrm{C}$ was added sodium hydride $(60 \% \mathrm{w} / \mathrm{w}$ in mineral oil, $773 \mathrm{mg}, 19.3 \mathrm{mmol})$ portionwise over $10 \mathrm{mins}$. Once addition was complete, the mixture was stirred at $0{ }^{\circ} \mathrm{C}$ for a further $40 \mathrm{~min}$ before iodomethane $(3.74 \mathrm{~g}$, $26.4 \mathrm{mmol}$ ) was added and the reaction mixture allowed to warm to RT and stirred for $1 \mathrm{~h}$. Water was added to quench the reaction and the resulting mixture extracted twice with ethyl acetate. The combined organics were dried $\left(\mathrm{MgSO}_{4}\right)$, filtered and concentrated. Purification by column chromatography (330 g, 0-20\% ethyl acetate in petroleum ether) gave $\mathbf{8 3}(971 \mathrm{mg}, 25 \%$ ) as a colorless oil. ${ }^{1} \mathrm{H}$ NMR $\left(400 \mathrm{MHz}, \mathrm{CDCl}_{3}\right) \delta 7.31(\mathrm{~s}, 2 \mathrm{H}), 7.12(\mathrm{~s}, 1 \mathrm{H}), 3.85(\mathrm{q}, J=7.2 \mathrm{~Hz}, 1 \mathrm{H})$, $2.37(\mathrm{~s}, 3 \mathrm{H}), 1.64(\mathrm{~d}, J=7.2 \mathrm{~Hz}, 3 \mathrm{H})$.

Step 3. To a solution of $83(970 \mathrm{mg}, 4.33 \mathrm{mmol})$ in THF $(20 \mathrm{~mL})$ at $0{ }^{\circ} \mathrm{C}$, was added sodium hydride $(60 \%$ in mineral oil, $190 \mathrm{mg}, 4.76 \mathrm{mmol})$ portionwise over $10 \mathrm{~min}$. Once added, the mixture was stirred at $0{ }^{\circ} \mathrm{C}$ for a further $40 \mathrm{~min}$ before iodoethane $(1.01 \mathrm{~g}, 6.49 \mathrm{mmol})$ was added. The reaction mixture was allowed to warm to RT and then stirred for $3 \mathrm{~h}$. Water was added to quench the reaction and the resulting mixture extracted twice with ethyl acetate. The combined organics were washed with water, brine, dried $\left(\mathrm{MgSO}_{4}\right)$, filtered and concentrated. Purification by column chromatography (330 g, 0-10\% ethyl acetate in petroleum ether) gave $84(872 \mathrm{mg}, 80 \%)$ as a colorless oil. ${ }^{1} \mathrm{H}$ NMR $\left(400 \mathrm{MHz}, \mathrm{CDCl}_{3}\right) \delta 7.35(\mathrm{~s}, 1 \mathrm{H}), 7.29(\mathrm{~s}, 1 \mathrm{H}), 7.20(\mathrm{~s}, 1 \mathrm{H}), 2.37(\mathrm{~s}$, $3 \mathrm{H}), 1.98-1.91$ (m, 2H), 1.69 (s, 3H), 0.98 (t, $J=7.2 \mathrm{~Hz}, 3 \mathrm{H})$.

Step 4. A mixture of $\mathbf{3 0}$ (1.68 g, $3.45 \mathrm{mmol}), \mathbf{8 4}(871 \mathrm{mg}, 3.45 \mathrm{mmol})$ and $\mathrm{Na}_{2} \mathrm{CO}_{3}(2 \mathrm{M}, 10.36$ $\mathrm{mmol})$ in dioxane $(43 \mathrm{~mL})$ was degassed and flushed with nitrogen five times. $\mathrm{Pd}\left[\mathrm{P}\left({ }^{\mathrm{t}} \mathrm{Bu}\right)_{3}\right]_{2}(88.3$ $\mathrm{mg}, 0.173 \mathrm{mmol}$ ) was added and the reaction vessel flushed with nitrogen three times and then heated at $60{ }^{\circ} \mathrm{C}$ for $3 \mathrm{~h}$. The mixture was diluted with ethyl acetate, water and brine and the organics passed through a Celite pad and concentrated in vacuo. Purification by column chromatography (120 g, 0-15\% ethyl acetate in petroleum ether) gave 85 as an off white foam. ${ }^{1} \mathrm{H}$ 
NMR (400 MHz, $\left.\mathrm{CDCl}_{3}\right) \delta 8.31(\mathrm{~d}, J=4.8 \mathrm{~Hz}, 1 \mathrm{H}), 8.23(\mathrm{~s}, 1 \mathrm{H}), 7.59(\mathrm{~s}, 1 \mathrm{H}), 7.49(\mathrm{~s}, 1 \mathrm{H}), 7.41$ $(\mathrm{s}, 1 \mathrm{H}), 7.32-7.26(\mathrm{~m}, 5 \mathrm{H}), 7.12(\mathrm{~d}, J=4.8 \mathrm{~Hz}, 1 \mathrm{H}), 2.50(\mathrm{~s}, 3 \mathrm{H}), 2.05-2.00(\mathrm{~m}, 2 \mathrm{H}), 1.78(\mathrm{~s}, 3 \mathrm{H})$, $1.04(\mathrm{t}, J=7.2 \mathrm{~Hz}, 3 \mathrm{H})$. LRMS found for $\mathrm{M}^{+}+1,533.3, \mathrm{C}_{37} \mathrm{H}_{33} \mathrm{~N}_{4}$ requires 533.3.

Step 5. To a solution of $85(720 \mathrm{mg}, 1.35 \mathrm{mmol})$ in DCM $(30 \mathrm{~mL})$ at $0{ }^{\circ} \mathrm{C}$ was added triethylsilane $(629 \mathrm{mg}, 5.41 \mathrm{mmol})$ followed by a solution of TFA $(2.08 \mathrm{~mL}, 27.0 \mathrm{mmol})$ in DCM $(30 \mathrm{~mL})$ and the reaction mixture allowed to warm to room temperature over $4 \mathrm{~h}$, followed by stirring overnight. The reaction was concentrated in vacuo and then ethyl acetate, saturated aq. $\mathrm{NaHCO}_{3}$ and brine were added. The organics were dried $\left(\mathrm{MgSO}_{4}\right)$, filtered and concentrated in vacuo. Purification by column chromatography ( $80 \mathrm{~g}, 0-5 \% \mathrm{MeOH}$ in DCM) gave 86 (286 mg, $73 \%)$ as an off white foam. ${ }^{1} \mathrm{H}$ NMR $\left(400 \mathrm{MHz}, \mathrm{DMSO}-d_{6}\right) \delta 8.60(\mathrm{~d}, J=4.6 \mathrm{~Hz}, 1 \mathrm{H}), 8.29(\mathrm{~s}$, 1H), $7.70(\mathrm{~s}, 1 \mathrm{H}), 7.66(\mathrm{~s}, 1 \mathrm{H}), 7.47(\mathrm{~s}, 1 \mathrm{H}), 7.39(\mathrm{~d}, J=4.6 \mathrm{~Hz}, 1 \mathrm{H}), 2.48(\mathrm{~s}, 3 \mathrm{H}), 2.09-2.02(\mathrm{~m}$, $2 \mathrm{H}), 1.75(\mathrm{~s}, 3 \mathrm{H}), 0.92(\mathrm{t}, J=7.2 \mathrm{~Hz}, 3 \mathrm{H})$. LRMS found for $\mathrm{M}^{+}+1,291.1, \mathrm{C}_{18} \mathrm{H}_{19} \mathrm{~N}_{4}$ requires 291.2 .

Step 6. To a solution of $\mathbf{8 6}(252 \mathrm{mg}, 0.868 \mathrm{mmol})$ in THF $(20 \mathrm{~mL})$ at room temperature was added $\mathrm{LiAlH}_{4}(2 \mathrm{M}$ in THF, $2.388 \mathrm{~g}, 5.21 \mathrm{mmol})$ and the reaction mixture stirred overnight. The reaction quenched with water, diluted with ethyl acetate and passed through a pad of Celite. The organic layer was collected, washed with water, brine, dried $\left(\mathrm{MgSO}_{4}\right)$, filtered and concentrated in vacuo. The crude product was purified by Fractionlynx prep LCMS (aq. TFA/MeCN) and the TFA removed by passing the fractions through an SPE bicarbonate cartridge. Freeze-drying gave $12(112 \mathrm{mg}, 44 \%)$ as a white solid. ${ }^{1} \mathrm{H}$ NMR (400 MHz, DMSO- $\left.d_{6}\right) \delta 8.57(\mathrm{~d}, J=4.6 \mathrm{~Hz}, 1 \mathrm{H})$, $8.26(\mathrm{~s}, 1 \mathrm{H}), 7.53(\mathrm{~s}, 1 \mathrm{H}), 7.48(\mathrm{~s}, 1 \mathrm{H}), 7.35(\mathrm{~d}, J=4.6 \mathrm{~Hz}, 1 \mathrm{H}), 7.29(\mathrm{~s}, 1 \mathrm{H}), 3.40-3.15(\mathrm{~m}, 2 \mathrm{H})$, $2.83(\mathrm{~d}, J=12.8 \mathrm{~Hz}, 1 \mathrm{H}), 2.66(\mathrm{~d}, J=12.8 \mathrm{~Hz}, 1 \mathrm{H}), 2.44(\mathrm{~s}, 3 \mathrm{H}), 1.84-1.77(\mathrm{~m}, 1 \mathrm{H}), 1.59-1.53$ $(\mathrm{m}, 1 \mathrm{H}), 1.29(\mathrm{~s}, 3 \mathrm{H}), 0.68(\mathrm{t}, J=7.2 \mathrm{~Hz}, 3 \mathrm{H})$. Mass spectrum (ESI) $m / z 295.2[\mathrm{M}+\mathrm{H}]^{+}$. HRMS found for $\mathrm{M}^{+}+1,295.1917, \mathrm{C}_{18} \mathrm{H}_{23} \mathrm{~N}_{4}$ requires 295.1917.

2-(3-Ethyl-5-(1H-pyrazolo[3,4-b]pyridin-4-yl)phenyl)-2-methylbutan-1-amine (13). Step 1. To a slurry of sodium hydride $(60 \% \mathrm{w} / \mathrm{w}$ in mineral oil, $9.54 \mathrm{~g}, 238 \mathrm{mmol})$ and 1,3-dibromo-5fluorobenzene $(10 \mathrm{~mL}, 79.5 \mathrm{mmol})$ in NMP $(100 \mathrm{~mL})$ at $5{ }^{\circ} \mathrm{C}$ was added ethyl cyanoacetate $(27.0$ $\mathrm{g}, 238 \mathrm{mmol})$ in NMP $(20 \mathrm{~mL})$ dropwise over $1 \mathrm{~h}$ maintaining the temperature below $10^{\circ} \mathrm{C}$. After complete addition and the effervescence subsided, the reaction was sealed and heated to $120^{\circ} \mathrm{C}$ overnight. The reaction mixture was allowed to cool and the contents poured into a mixture of ethyl acetate $(200 \mathrm{~mL}), 1 \mathrm{M} \mathrm{HCl}(200 \mathrm{~mL})$ and water $(200 \mathrm{~mL})$. The organic layer was separated and the aqueous was extracted with ethyl acetate $(2 \times 200 \mathrm{~mL})$. The organic extracts were combined, washed with brine, dried $\left(\mathrm{MgSO}_{4}\right)$, filtered and concentrated to give the crude product. Purification by silica gel flash chromatography (0-100\% ethyl acetate/petroleum ether) gave 67 $(16.9 \mathrm{~g}, 61 \%)$ as a waxy off-white solid. ${ }^{1} \mathrm{H}$ NMR $\left(400 \mathrm{MHz}, \mathrm{CDCl}_{3}\right) \delta 7.75(\mathrm{~s}, 1 \mathrm{H}), 7.59(\mathrm{~s}, 1 \mathrm{H})$, $7.58(\mathrm{~s}, 1 \mathrm{H}), 4.33-4.28(\mathrm{~m}, 2 \mathrm{H}), 1.37-1.32(\mathrm{~m}, 3 \mathrm{H})$. LRMS found for $\mathrm{M}^{+}+1,348.0$, $\mathrm{C}_{11} \mathrm{H}_{10} \mathrm{Br}_{2} \mathrm{NO}_{2}$ requires 345.91 .

Step 2. A mixture of $67(22.2 \mathrm{~g}, 63.9 \mathrm{mmol})$ and $\mathrm{LiCl}(1.7 \mathrm{~g}, 40.1 \mathrm{mmol})$ in DMSO (70 mL) and water $(35 \mathrm{~mL})$ was heated at $165^{\circ} \mathrm{C}$ for $90 \mathrm{~min}$. After cooling to room temperature, the reaction mixture was poured into iced water and extracted with ethyl acetate $(3 \times 200 \mathrm{~mL})$. The combined organics were washed with brine, dried $\left(\mathrm{MgSO}_{4}\right)$ and concentrated to give a colourless oil. Purification by silica gel flash chromatography (10-20\% ethyl acetate/petroleum ether) gave $\mathbf{6 8}$ $(14.9 \mathrm{~g}, 85 \%)$ as a white powder. ${ }^{1} \mathrm{H}$ NMR $\left(400 \mathrm{MHz}, \mathrm{CDCl}_{3}\right) \delta 7.68(\mathrm{~s}, 1 \mathrm{H}), 7.47(\mathrm{~s}, 1 \mathrm{H}), 7.28$ (s, 1H), $3.74(\mathrm{~s}, 2 \mathrm{H})$. LRMS found for $\mathrm{M}^{+}-\mathrm{CN}, 247.0, \mathrm{C}_{7} \mathrm{H}_{6} \mathrm{Br}_{2}$ requires 247.9.

Step 3. To a solution of $\mathbf{6 8}(3 \mathrm{~g}, 10.9 \mathrm{mmol})$ in THF $(40 \mathrm{~mL})$ at $0{ }^{\circ} \mathrm{C}$ was added sodium hydride $(60 \% \mathrm{w} / \mathrm{w}$ in mineral oil, $480 \mathrm{mg}, 12.0 \mathrm{mmol})$ portionwise over $10 \mathrm{~min}$. Once added, the mixture was stirred at $0{ }^{\circ} \mathrm{C}$ for a further $40 \mathrm{~min}$ before iodomethane $(2.32 \mathrm{~g}, 16.4 \mathrm{mmol})$ was added. The mixture was allowed to warm to room temperature and stirred for $1 \mathrm{~h}$. The reaction was quenched with water and extracted with ethyl acetate twice. The organic layers were combined, washed 
with water, brine, dried $\left(\mathrm{MgSO}_{4}\right)$, filtered and concentrated in vacuo. Purification by column chromatography (120 g, 0-15\% ethyl acetate in petroleum ether) gave $69(1.96 \mathrm{~g}, 62 \%)$ as a yellow oil. ${ }^{1} \mathrm{H}$ NMR $\left(400 \mathrm{MHz}, \mathrm{CDCl}_{3}\right) \delta 7.67(\mathrm{~s}, 1 \mathrm{H}), 7.47(\mathrm{~s}, 2 \mathrm{H}), 3.87$ (q, $\left.J=7.3 \mathrm{~Hz}, 1 \mathrm{H}\right)$, $1.67(\mathrm{~d}, J=7.3 \mathrm{~Hz}, 3 \mathrm{H})$. LCMS found for $\mathrm{M}^{+}+1,288.0, \mathrm{C}_{9} \mathrm{H}_{8} \mathrm{Br}_{2} \mathrm{~N}$ requires 287.9.

Step 4. To a solution of $69(1.00 \mathrm{~g}, 3.46 \mathrm{mmol})$ in THF $(20 \mathrm{~mL})$ at $0{ }^{\circ} \mathrm{C}$ was added sodium hydride $(60 \% \mathrm{w} / \mathrm{w}$ in mineral oil, $152 \mathrm{mg}, 3.81 \mathrm{mmol})$. The mixture was stirred at $0{ }^{\circ} \mathrm{C}$ for a further $30 \mathrm{~min}$ before iodoethane $(810 \mathrm{mg}, 5.19 \mathrm{mmol})$ was added. The reaction mixture was allowed to warm to room temperature, stirred overnight and quenched with water. The mixture was extracted twice with ethyl acetate and the combined organics washed with water, brine, dried $\left(\mathrm{MgSO}_{4}\right)$, filtered and concentrated in vacuo. The crude product was purified by column chromatography ( $80 \mathrm{~g}, 0-15 \%$ ethyl acetate in petroleum ether) to give $70(771 \mathrm{mg}, 70 \%)$ as a yellow oil. ${ }^{1} \mathrm{H}$ NMR $\left(400 \mathrm{MHz}, \mathrm{CDCl}_{3}\right) \delta 7.65(\mathrm{~s}, 1 \mathrm{H}), 7.53(\mathrm{~s}, 2 \mathrm{H}), 1.98-1.92(\mathrm{~m}, 2 \mathrm{H}), 1.71(\mathrm{~s}$, $3 \mathrm{H}), 1.00$ (t, $J=7.4 \mathrm{~Hz}, 3 \mathrm{H})$.

Step 5. In a 2-neck flask under nitrogen was placed iPrMgCl.LiCl (14 \%w/v, $2.52 \mathrm{~mL} ; 2.43$ $\mathrm{mmol})$ and the flask cooled to $-20^{\circ} \mathrm{C} .70(770 \mathrm{mg}, 2.429 \mathrm{mmol})$ in THF $(1 \mathrm{~mL})$ was added and the reaction stirred for $1.5 \mathrm{~h}$ at -15 to $-5^{\circ} \mathrm{C}$. 2-Methoxy-4,4,5,5-tetramethyl-1,3,2-dioxaborolane (384 mg, $2.43 \mathrm{mmol}$ ) was added and the reaction allowed to warm to $\mathrm{rt} \mathrm{o} / \mathrm{n}$. Saturated aq. $\mathrm{NH}_{4} \mathrm{Cl}$ solution was added followed by ethyl acetate and water and the mixture was extracted three times with ethyl acetate. The combined organics were dried $\left(\mathrm{MgSO}_{4}\right)$, filtered and concentrated in vacuo. The crude product was purified by column chromatography (40 g, 3-40\% ethyl acetate in petroleum ether) to give 71 (448 $\mathrm{mg}, 51 \%$ ) as a yellow solid. ${ }^{1} \mathrm{H}$ NMR $\left(400 \mathrm{MHz}, \mathrm{CDCl}_{3}\right) \delta 7.89$ (s, 1H), 7.75 (s, 1H), 7.69 (s, 1H), 1.99 (q, $J=7.4 \mathrm{~Hz}, 2 \mathrm{H}), 1.73$ (s, 3H), 1.36 (s, 2H), 0.99 (t, $J=$ $7.4 \mathrm{~Hz}, 3 \mathrm{H})$.

Step 6. A mixture of 71 (366 mg, $1.01 \mathrm{mmol}$ ), 4-iodo- $1 H$-pyrazolo[3,4-b]pyridine (296 mg, 1.21 $\mathrm{mmol}), \mathrm{Pd}\left(\mathrm{PPh}_{3}\right)_{4}(58 \mathrm{mg}, 50.3 \mu \mathrm{mol})$ and $\mathrm{Na}_{2} \mathrm{CO}_{3}(2 \mathrm{M}, 4.02 \mathrm{mmol})$ in DME $(9 \mathrm{~mL})$ was heated in the microwave for $30 \mathrm{~min}$ at $150{ }^{\circ} \mathrm{C}$. The reaction mixture was diluted with ethyl acetate and water and the layers separated. After extraction with a further portion of ethyl acetate, the combined organics were dried $\left(\mathrm{MgSO}_{4}\right)$, filtered and concentrated in vacuo. The crude product was purified by column chromatography ( $40 \mathrm{~g}, 5-70 \%$ ethyl acetate in petroleum ether) to give 72 $(182 \mathrm{mg}, 51 \%)$ as an off white solid. ${ }^{1} \mathrm{H} \mathrm{NMR}\left(400 \mathrm{MHz}, \mathrm{CDCl}_{3}\right) \delta 8.72(\mathrm{~d}, J=4.8 \mathrm{~Hz}, 1 \mathrm{H}), 8.29$ (s, 1H), $7.90(\mathrm{~s}, 1 \mathrm{H}), 7.81(\mathrm{~s}, 1 \mathrm{H}), 7.75(\mathrm{~s}, 1 \mathrm{H}), 7.35$ (d, $J=4.8 \mathrm{~Hz}, 1 \mathrm{H}), 4.14(\mathrm{q}, J=7.2 \mathrm{~Hz}, 2 \mathrm{H})$, $1.81(\mathrm{~s}, 3 \mathrm{H}), 1.08(\mathrm{t}, J=7.2 \mathrm{~Hz}, 3 \mathrm{H})$. LCMS found for $\mathrm{M}^{+}+1,357.1, \mathrm{C}_{17} \mathrm{H}_{16} \mathrm{BrN}_{4}$ requires

355.1 .

Step 7. 72 (60 mg, $0.169 \mathrm{mmol})$ and vinylboronic acid pinacol ester ( $39 \mathrm{mg}, 0.253 \mathrm{mmol})$ were placed in a small microwave vial. DME $(2 \mathrm{~mL})$ was then added followed by sodium carbonate $(2 \mathrm{M}, 0.562 \mathrm{mmol})$ and $\mathrm{Pd}\left(\mathrm{PPh}_{3}\right)_{4}(15.6 \mathrm{mg}, 13.5 \mu \mathrm{mol})$ and the reaction was heated in the microwave at $150{ }^{\circ} \mathrm{C}$ for $30 \mathrm{~min}$. The reaction mixture was diluted with ethyl acetate and water and the aqueous layer was extracted three times with ethyl acetate. The combined organics were dried $\left(\mathrm{MgSO}_{4}\right)$, filtered and concentrated in vacuo. The crude product was purified by column chromatography ( $12 \mathrm{~g}, 10-60 \%$ ethyl acetate in petroleum ether) to give $\mathbf{7 3}(29 \mathrm{mg}, 57 \%$ ) as an off white solid. ${ }^{1} \mathrm{H}$ NMR $\left(400 \mathrm{MHz}, \mathrm{CDCl}_{3}\right) \delta 8.66(\mathrm{dd}, J=4.9,2.7 \mathrm{~Hz}, 1 \mathrm{H}), 8.19(\mathrm{~d}, J=5.4 \mathrm{~Hz}$, $1 \mathrm{H}), 7.72(\mathrm{~d}, J=9.6 \mathrm{~Hz}, 1 \mathrm{H}), 7.65(\mathrm{~s}, 1 \mathrm{H}), 7.25(\mathrm{dd}, J=14.9,4.8 \mathrm{~Hz}, 2 \mathrm{H}), 6.77$ (dd, $J=17.6$, $10.9 \mathrm{~Hz}, 1 \mathrm{H}), 5.85(\mathrm{~d}, J=17.6 \mathrm{~Hz}, 1 \mathrm{H}), 5.37(\mathrm{~d}, J=10.9 \mathrm{~Hz}, 1 \mathrm{H}), 1.75-1.71(\mathrm{~m}, 2 \mathrm{H}), 1.19$ (s, $3 \mathrm{H}), 0.99(\mathrm{t}, J=7.4 \mathrm{~Hz}, 3 \mathrm{H})$. LCMS found for $\mathrm{M}^{+}+1,303.1, \mathrm{C}_{19} \mathrm{H}_{19} \mathrm{~N}_{4}$ requires 302.2.

Step 8. 73 (29 mg, $95.9 \mu \mathrm{mol})$ was dissolved in methanol (3 mL), 10\% Pd/C (Degussa wet, $5 \mathrm{mg}$ ) was added, the reaction placed under an atmosphere of hydrogen and stirred at room temperature for $2 \mathrm{~h}$. The reaction was filtered through Celite, washed with $\mathrm{MeOH}$ and concentrated in vacuo to give the crude product $\mathbf{7 5}$ ( $26 \mathrm{mg}, 89 \%$ ), which was taken on to the next step without further purification. LCMS found for $\mathrm{M}^{+}+1,305.2, \mathrm{C}_{19} \mathrm{H}_{21} \mathrm{~N}_{4}$ requires 305.2. 
Step 9. 75 (26 mg, $85.4 \mu \mathrm{mol})$ was dissolved in THF (1.5 mL) and $\mathrm{LiAlH}_{4}(2 \mathrm{M}$ in THF, 0.342 mmol) was added and the reaction stirred at room temperature overnight. Saturated aq. $\mathrm{NaHCO}_{3}$ solution was added followed by ethyl acetate. The mixture was extracted twice more with ethyl acetate and the combined organics dried $\left(\mathrm{MgSO}_{4}\right)$, filtered and concentrated in vacuo. Purified by Fractionlynx prep LCMS (aq. TFA/MeCN) gave $\mathbf{1 3}\left(3.5 \mathrm{mg}, 8 \%\right.$ ) as a white solid. ${ }^{1} \mathrm{H}$ NMR (400 MHz, DMSO- $\left.d_{6}\right) \delta 13.82(\mathrm{~s}, 1 \mathrm{H}), 8.60(\mathrm{~d}, J=4.8 \mathrm{~Hz}, 1 \mathrm{H}), 8.31(\mathrm{~s}, 1 \mathrm{H}), 7.73-7.52(\mathrm{~m}, 2 \mathrm{H}), 7.45$ - 7.34 (m, 2H), 3.90-3.40 (br s, 2H), 3.30 (dd, $J=12.9,6.2 \mathrm{~Hz}, 1 \mathrm{H}), 3.07$ (dd, $J=13.0,6.3 \mathrm{~Hz}$, $1 \mathrm{H}), 2.77(\mathrm{q}, J=7.6 \mathrm{~Hz}, 2 \mathrm{H}), 1.86(\mathrm{dq}, J=14.9,7.8 \mathrm{~Hz}, 1 \mathrm{H}), 1.66(\mathrm{dt}, J=14.0,7.2 \mathrm{~Hz}, 1 \mathrm{H}), 1.42$ $(\mathrm{s}, 3 \mathrm{H}), 1.29(\mathrm{t}, J=7.6 \mathrm{~Hz}, 3 \mathrm{H}), 0.66(\mathrm{t}, J=7.3 \mathrm{~Hz}, 3 \mathrm{H})$. HRMS found for $\mathrm{M}^{+}+1,309.2080$, $\mathrm{C}_{19} \mathrm{H}_{25} \mathrm{~N}_{4}$ requires 309.2074 .

2-methyl-2-(3-propyl-5-(1H-pyrazolo[3,4-b]pyridin-4-yl)phenyl)butan-1-amine (14). Step 1. $72(60 \mathrm{mg}, 0.169 \mathrm{mmol})$ and allylboronic acid pinacol ester $(42.6 \mathrm{mg}, 0.253 \mathrm{mmol})$ were placed in a small microwave vial. DME $(2 \mathrm{~mL})$ was then added followed by sodium carbonate $(2 \mathrm{M}$, $0.562 \mathrm{mmol})$ and $\mathrm{Pd}\left(\mathrm{PPh}_{3}\right)_{4}(15.6 \mathrm{mg}, 13.5 \mu \mathrm{mol})$. The reaction mixture was heated in the microwave at $150{ }^{\circ} \mathrm{C}$ for $30 \mathrm{~min}$. ethyl acetate and water were added and the aqueous layer was extracted three times with ethyl acetate, dried $\left(\mathrm{MgSO}_{4}\right)$, filtered and concentrated in vacuo. Purification by column chromatography (12 g, 10-70\% ethyl acetate/petroleum ether) gave 74 (26 $\mathrm{mg}, 49 \%)$ as an off white solid. ${ }^{1} \mathrm{H}$ NMR $\left(400 \mathrm{MHz}, \mathrm{CDCl}_{3}\right) \delta 12.74(\mathrm{br} \mathrm{s}, 1 \mathrm{H}), 8.63(\mathrm{~d}, J=4.8$ $\mathrm{Hz}, 1 \mathrm{H}), 8.18(\mathrm{~s}, 1 \mathrm{H}), 7.61(\mathrm{~s}, 1 \mathrm{H}), 7.51(\mathrm{~s}, 1 \mathrm{H}), 7.35(\mathrm{~s}, 1 \mathrm{H}), 7.24(\mathrm{~d}, J=4.8 \mathrm{~Hz}, 1 \mathrm{H}), 6.02-5.93$ $(\mathrm{m}, 1 \mathrm{H}), 5.09-5.07(\mathrm{~m}, 2 \mathrm{H}), 4.08-4.02(\mathrm{~m}, 2 \mathrm{H}), 3.49-3.47(\mathrm{~m}, 2 \mathrm{H}), 1.71(\mathrm{~s}, 3 \mathrm{H}), 0.98(\mathrm{t}, \mathrm{J}=7.2$ $\mathrm{Hz}, 3 \mathrm{H})$. LCMS found for $\mathrm{M}^{+}+1,317.1, \mathrm{C}_{20} \mathrm{H}_{21} \mathrm{~N}_{4}$ requires 317.2.

Step 2. 74 (20 mg, $63.2 \mu \mathrm{mol})$ was dissolved in $\mathrm{MeOH}(3 \mathrm{~mL}) . \mathrm{Pd} / \mathrm{C}(10 \%$, Degussa-type, $5 \mathrm{mg})$ was added and the reaction was placed under an atmosphere of hydrogen and stirred at room temperature for $2 \mathrm{~h}$. Filtration through Celite concentrated in vacuo gave 76 (16 mg, 79\%). LCMS found for $\mathrm{M}^{+}+1,319.2, \mathrm{C}_{20} \mathrm{H}_{23} \mathrm{~N}_{4}$ requires 319.2.

Step 3. $76(16 \mathrm{mg}, 50.3 \mu \mathrm{mol})$ was dissolved in THF $(1.5 \mathrm{~mL})$ and $\mathrm{LiAlH}_{4}(2 \mathrm{M}$ in THF, 0.201 mmol) was added and stirring continued overnight at room temperature. Saturated aq. $\mathrm{NaHCO}_{3}$ solution and ethyl acetate were added. The aqueous layer was extracted three times with ethyl acetate and the combined organics dried $\left(\mathrm{MgSO}_{4}\right)$, filtered and concentrated in vacuo. Purified by Fractionlynx prep LCMS (aq. TFA/MeCN) gave $14(5.4 \mathrm{mg}, 20 \%)$ as a white solid. ${ }^{1} \mathrm{H}$ NMR $\left(400 \mathrm{MHz}, \mathrm{DMSO}-d_{6}\right) \delta 13.73(\mathrm{~s}, 1 \mathrm{H}), 8.51(\mathrm{~d}, J=4.8 \mathrm{~Hz}, 1 \mathrm{H}), 8.22(\mathrm{~s}, 1 \mathrm{H}), 7.55-7.51(\mathrm{~s}, 2 \mathrm{H})$, $7.32(\mathrm{~d}, J=4.8 \mathrm{~Hz}, 1 \mathrm{H}), 7.29(\mathrm{~s}, 1 \mathrm{H}), 5.00-3.61$ (br s, $1 \mathrm{H}), 3.21(\mathrm{dt}, J=11.7,6.0 \mathrm{~Hz}, 1 \mathrm{H}), 2.99$ $(\mathrm{dd}, J=12.8,6.2 \mathrm{~Hz}, 1 \mathrm{H}), 2.63(\mathrm{dd}, J=8.5,6.7 \mathrm{~Hz}, 2 \mathrm{H}), 1.77(\mathrm{dt}, J=14.4,7.2 \mathrm{~Hz}, 1 \mathrm{H}), 1.63-$ $1.55(\mathrm{~m}, 4 \mathrm{H}), 1.34(\mathrm{~s}, 3 \mathrm{H}), 0.88(\mathrm{t}, J=7.3 \mathrm{~Hz}, 3 \mathrm{H}), 0.57(\mathrm{t}, J=7.3 \mathrm{~Hz}, 3 \mathrm{H})$. HRMS found for $\mathrm{M}^{+}$ $+1,323.2238, \mathrm{C}_{20} \mathrm{H}_{27} \mathrm{~N}_{4}$ requires 323.2230.

2-Methyl-2-(3-(3-methyl-1H-pyrazolo[3,4-b]pyridin-4-yl)phenyl)butan-1-amine (15). Step 1. Diisopropylamine $(1.62 \mathrm{~g}, 16.0 \mathrm{mmol})$ was dissolved in dry THF $(12 \mathrm{~mL})$ and cooled to $-70{ }^{\circ} \mathrm{C}$. $\mathrm{n}$-BuLi (2.5 $\mathrm{M}$ in hexanes, $15.4 \mathrm{mmol})$ was added slowly dropwise, keeping the temperature below $-60{ }^{\circ} \mathrm{C}$, and the resultant mixture was stirred at $0{ }^{\circ} \mathrm{C}$ for 2 min and then re-cooled to -70 ${ }^{\circ} \mathrm{C}$. A solution of 2-fluoro-3-iodopyridine $(3.11 \mathrm{~g}, 14.0 \mathrm{mmol})$ in dry THF $(9 \mathrm{~mL})$ was added slowly dropwise and this solution was stirred at $-70{ }^{\circ} \mathrm{C}$ for $2 \mathrm{~h}$. Acetaldehyde $(3.07 \mathrm{~g}, 69.8 \mathrm{mmol})$ was added slowly dropwise over $20 \mathrm{~min}$ and the resulting mixture stirred at $-70{ }^{\circ} \mathrm{C}$ for $1 \mathrm{~h}$. The reaction was quenched by addition of water $(12 \mathrm{~mL})$ at $-70{ }^{\circ} \mathrm{C}$ and the resulting mixture was partitioned with ethyl acetate and the aqueous layer extracted with ethyl acetate $(3 \times 50 \mathrm{~mL})$. The combined organics were dried over $\left(\mathrm{Na}_{2} \mathrm{SO}_{4}\right)$, filtered and concentrated in vacuo. Purification by column chromatography (30\% ethyl acetate in hexanes) gave $31(3.34 \mathrm{~g}, 90 \%)$ as a light yellow viscous gum. ${ }^{1} \mathrm{H}$ NMR $\left(400 \mathrm{MHz}, \mathrm{DMSO}-d_{6}\right) \delta$ 7.81-7.79 (m, 1H), 7.76-7.75 (m, 1H), 5.06-5.00 
(m, $1 \mathrm{H}), 1.39(\mathrm{dd}, J=6.8,0.8 \mathrm{~Hz}, 3 \mathrm{H}) .{ }^{19} \mathrm{~F}$ NMR (400 MHz, DMSO- $\left.d_{6}\right) \delta$-65.8. LRMS found for $\mathrm{M}^{+}+1,267.9, \mathrm{C}_{7} \mathrm{H}_{8} \mathrm{FINO}$ requires 268.0.

Step 2. 31 (3.25 g, $12.2 \mathrm{mmol}$ ) was dissolved in toluene (40 mL) and $\mathrm{MnO}_{2}(12.5 \mathrm{~g}, 122 \mathrm{mmol})$ was added in one portion. The resulting suspension was stirred at reflux for $90 \mathrm{~min}$. The reaction mixture was allowed to cool to room temperature and filtered through Celite, washing copiously with ethyl acetate. The filtrate was concentrated in vacuo. Purification by column chromatography ( $15 \%$ ethyl acetate in hexanes) gave $33(1.92 \mathrm{~g}, 60 \%)$ as a light yellow solid. ${ }^{1} \mathrm{H}$ NMR (400 MHz, DMSO- $\left.d_{6}\right) \delta$ 8.03-7.99 (m, 1H), 7.96-7.94 (m, 1H), $2.57(\mathrm{~s}, 3 \mathrm{H}) .{ }^{19} \mathrm{~F}$ NMR $(400$ $\left.\mathrm{MHz}, \mathrm{DMSO}-d_{6}\right) \delta$-68.7. LRMS found for $\mathrm{M}^{+}+1,265.9, \mathrm{C}_{7} \mathrm{H}_{6} \mathrm{FINO}$ requires 267.0.

Step 3. 33 (1.90 g, $7.17 \mathrm{mmol})$ was dissolved in THF $(8 \mathrm{~mL})$ in a pressure tube and hydrazine (1 $\mathrm{M}$ in THF, $15.8 \mathrm{mmol}$ ) was added slowly dropwise. The resultant yellow, opaque suspension was stirred at $90{ }^{\circ} \mathrm{C}$ for $45 \mathrm{~min}$. The reaction was allowed to cool to room temperature, partitioned between ethyl acetate and saturated $\mathrm{Na}_{2} \mathrm{CO}_{3}$. The aqueous layer was extracted with ethyl acetate $(3 \times 50 \mathrm{~mL})$ and the combined organics were dried $\left(\mathrm{Na}_{2} \mathrm{SO}_{4}\right)$, filtered and concentrated in vacuo. Purification by column chromatography ( $50 \%$ ethyl acetate in hexanes) was followed by further purification by column chromatography $\left(60 \% \mathrm{CH}_{3} \mathrm{CN}\right.$ in water, $200 \mathrm{~mL}$ reverse phase silica) to give an off-white solid after concentration. This material was redissolved in ethyl acetate/ $\mathrm{MeOH}$, dried $\left(\mathrm{Na}_{2} \mathrm{SO}_{4}\right)$, filtered and concentrated in vacuo to give a light yellow solid. Trituration in pentane using an ultrasonic bath gave $35(532 \mathrm{mg}, 29 \%)$ as a salmon-pink powder. ${ }^{1} \mathrm{H}$ NMR (400 MHz, DMSO- $\left.d_{6}\right) \delta 13.5($ br s, $1 \mathrm{H}), 8.05(\mathrm{~d}, J=4.4 \mathrm{~Hz}, 1 \mathrm{H}), 7.64(\mathrm{~d}, J=4.4 \mathrm{~Hz}, 1 \mathrm{H}), 2.62$ (s, $3 \mathrm{H})$. LRMS found for $\mathrm{M}^{+}+1,260.0, \mathrm{C}_{7} \mathrm{H}_{7} \mathrm{IN}_{3}$ requires 259.97 .

Step 4. 56 (114 mg, $4.78 \mathrm{mmol})$ was dissolved in THF $(20 \mathrm{~mL})$ and cooled in an ice-bath. Alane:dimethylethylamine complex, $(0.5 \mathrm{M}$ solution in toluene, $14.4 \mathrm{mmol})$ was added slowly dropwise over $12 \mathrm{~min}$ and the resultant mixture stirred at $0{ }^{\circ} \mathrm{C}$ for $15 \mathrm{~min}$ and at room temperature overnight. The reaction was quenched by the slow addition of $1: 1$ water:THF (20 $\mathrm{mL}$ ) and the resulting suspension stirred vigorously for $5 \mathrm{~min}$ and filtered through Celite. The collected solid was washed copiously with ethyl acetate/water and the filtrate was concentrated in vacuo. This material was partitioned between ethyl acetate and brine and the aqueous phase was extracted with ethyl acetate $(3 \times 50 \mathrm{~mL})$. The combined organics were dried $\left(\mathrm{Na}_{2} \mathrm{SO}_{4}\right)$, filtered and concentrated in vacuo. Purification by column chromatography ( $5 \% \mathrm{MeOH}$ in DCM) gave 58 (784 mg, 68\%) as a light yellow oil. ${ }^{1} \mathrm{H}$ NMR (400 MHz, DMSO- $\left.d_{6}\right) \delta 7.45-7.40(\mathrm{~m}, 1 \mathrm{H}), 7.39-$ $7.33(\mathrm{~m}, 1 \mathrm{H}), 7.32-7.25(\mathrm{~m}, 2 \mathrm{H}), 2.74(\mathrm{~d}, J=13.2 \mathrm{~Hz}, 1 \mathrm{H}), 2.58(\mathrm{~d}, J=13.2 \mathrm{~Hz}, 1 \mathrm{H}), 1.75-1.67$ $(\mathrm{m}, 1 \mathrm{H}), 1.60-1.42(\mathrm{~m}, 1 \mathrm{H}), 1.20(\mathrm{~s}, 3 \mathrm{H}), 0.60(\mathrm{t}, J=7.2 \mathrm{~Hz}, 1 \mathrm{H})$. LRMS found for $\mathrm{M}^{+}+1,244.1$ $\mathrm{C}_{11} \mathrm{H}_{17} \mathrm{BrN}$ requires 242.06 .

Step 5.58 (775 mg, $3.20 \mathrm{mmol})$ was dissolved in THF (7 mL) and water $(2 \mathrm{~mL}) . \mathrm{NaHCO}_{3}(807$ $\mathrm{mg}, 9.60 \mathrm{mmol}$ ) was added and the mixture was cooled in an ice-bath. Di-tert-butyl dicarbonate (733 mg, $3.36 \mathrm{mmol}$ ) was added in one portion and the resultant mixture allowed to warm to room temperature overnight. The reaction mixture was partitioned between ethyl acetate and brine. The aqueous layer was extracted with ethyl acetate $(3 \times 20 \mathrm{~mL})$ and the combined organics were dried $\left(\mathrm{Na}_{2} \mathrm{SO}_{4}\right)$, filtered and concentrated in vacuo. Purification by column chromatography (5\% ethyl acetate in hexanes) gave $\mathbf{5 9}(1.04 \mathrm{~g}, 95 \%)$ as a colourless oil. ${ }^{1} \mathrm{H}$ NMR $(400 \mathrm{MHz}$, DMSO- $\left.d_{6}\right) \delta 7.41-7.36(\mathrm{~m}, 2 \mathrm{H}), 7.29-7.26(\mathrm{~m}, 2 \mathrm{H}), 6.70-6.67(\mathrm{~m}, 1 \mathrm{H}), 3.23-3.14(\mathrm{~m}, 1 \mathrm{H}), 3.11-$ $3.00(\mathrm{~m}, 1 \mathrm{H}), 1.75-1.64(\mathrm{~m}, 1 \mathrm{H}), 1.52-1.40(\mathrm{~m}, 1 \mathrm{H}), 1.32(\mathrm{~s}, 9 \mathrm{H}), 1.19(\mathrm{~s}, 3 \mathrm{H}), 0.58(\mathrm{t}, J=7.2 \mathrm{~Hz}$, $3 \mathrm{H})$. LRMS found for $\mathrm{M}^{+}-\mathrm{C}_{4} \mathrm{H}_{8}, 288.0, \mathrm{C}_{12} \mathrm{H}_{16} \mathrm{BrN}_{2}$ requires 286.05 .

Step 6. 59 (1 g, $2.92 \mathrm{mmol}$ ), KOAc ( $860 \mathrm{mg}, 8.77 \mathrm{mmol}$ ), bis(pinacol)diboron ( $890 \mathrm{mg}, 3.51$ $\mathrm{mmol})$ and $\mathrm{Pd}(\mathrm{dppf}) \mathrm{Cl}_{2}$.DCM $(118 \mathrm{mg}, 0.146 \mathrm{mmol})$ were suspended/dissolved in dry dioxane $(10 \mathrm{~mL})$ and degassed by vacuum/nitrogen cycles (x5). The resultant was stirred at $90{ }^{\circ} \mathrm{C}$ for $5 \mathrm{~h}$. The reaction was allowed to cool to room temperature and filtered through Celite. The collected solid was washed copiously with ethyl acetate and the filtrate was concentrated in vacuo. 
Purification by column chromatography on florisil (10\% ethyl acetate in hexanes) gave $\mathbf{6 0}$ as a colourless gum $(1.01 \mathrm{~g}, 88 \%) .{ }^{1} \mathrm{H}$ NMR $\left(400 \mathrm{MHz}, \mathrm{DMSO}-d_{6}\right) \delta 7.57(\mathrm{~s}, 1 \mathrm{H}), 7.50-7.48(\mathrm{~m}, 1 \mathrm{H})$, 7.46-7.38 (m, 1H), 7.33 (t, J=7.2 Hz, 1H), 6.70-6.64 (m, 1H), 3.20-3.00 (m, 2H), 1.77-1.65 (m, $1 \mathrm{H}), 1.54-1.44(\mathrm{~m}, 1 \mathrm{H}), 1.32(\mathrm{~s}, 2 \mathrm{H}), 1.30(\mathrm{~s}, 9 \mathrm{H}), 0.58(\mathrm{~s}, 3 \mathrm{H}), 1.20(\mathrm{~s}, 3 \mathrm{H})$. LRMS found for $\mathrm{M}^{+}$ - $\mathrm{C}_{4} \mathrm{H}_{8}, 334.2, \mathrm{C}_{18} \mathrm{H}_{28} \mathrm{BNO}_{4}$ requires 333.21.

Step 7. 35 (150 mg, $0.579 \mathrm{mmol}), 60$ (225 mg, $0.579 \mathrm{mmol}), \mathrm{Na}_{2} \mathrm{CO}_{3}(2 \mathrm{M}, 1.74 \mathrm{mmol})$ and $\mathrm{Pd}\left(\mathrm{PPh}_{3}\right)_{4}(66.9 \mathrm{mg}, 57.9 \mu \mathrm{mol})$ were placed in a microwave tube and dioxane $(1.5 \mathrm{~mL})$ was added. The resulting suspension was stirred at $150{ }^{\circ} \mathrm{C}$ in the microwave for $45 \mathrm{~min}$. The reaction mixture was partitioned between ethyl acetate and brine. The aqueous layer was extracted with ethyl acetate $(3 \times 20 \mathrm{~mL})$ and the combined organics were dried $\left(\mathrm{Na}_{2} \mathrm{SO}_{4}\right)$, filtered and concentrated in vacuo. Purification by column chromatography ( $75 \%$ ethyl acetate in hexanes) gave a light yellow gum, which was dissolved in DCM $(2 \mathrm{~mL})$ and cooled in an ice-bath. TFA (2 $\mathrm{mL}$ ) was added dropwise and the resultant solution was stirred at $0{ }^{\circ} \mathrm{C}$ for $30 \mathrm{~min}$ and at $\mathrm{RT}$ for $30 \mathrm{~min}$. The reaction mixture was concentrated under reduced pressure to give a light brown gum. This material was partitioned between ethyl acetate and saturated $\mathrm{Na}_{2} \mathrm{CO}_{3}$. The aqueous layer was extracted with ethyl acetate $(3 \times 20 \mathrm{~mL})$ and the combined organics were dried $\left(\mathrm{Na}_{2} \mathrm{SO}_{4}\right)$, filtered and concentrated in vacuo. Purification by column chromatography $(9 \% \mathrm{MeOH}$ in $\mathrm{DCM}, 1 \%$ $\mathrm{NH}_{4} \mathrm{OH}, \sim 75 \mathrm{~mL}$ silica) gave a colourless gum. This material was lyophilized from $\mathrm{MeOH}$ (1 $\mathrm{mL}), \mathrm{CH}_{3} \mathrm{CN}(2 \mathrm{~mL})$ and water $(6 \mathrm{~mL})$ overnight to give 15 as an off-white powder $(73 \mathrm{mg}$, 71\%). ${ }^{1} \mathrm{H}$ NMR (400 MHz, DMSO- $\left.d_{6}\right) \delta 13.4$ (br s, $\left.1 \mathrm{H}\right), 8.49(\mathrm{~d}, J=4.7 \mathrm{~Hz}, 1 \mathrm{H}), 7.51-7.44$ (m, 2H), $7.40(\mathrm{~s}, 1 \mathrm{H}), 7.35(\mathrm{dt}, J=7.1,2.1 \mathrm{~Hz}, 1 \mathrm{H}), 7.04(\mathrm{~d}, J=4.8 \mathrm{~Hz}, 1 \mathrm{H}), 2.82(\mathrm{~d}, J=12.8 \mathrm{~Hz}$, $1 \mathrm{H}), 2.64(\mathrm{~d}, J=12.8 \mathrm{~Hz}, 1 \mathrm{H}), 2.16(\mathrm{~s}, 3 \mathrm{H}), 1.80-1.76(\mathrm{~m}, 1 \mathrm{H}), 1.55(\mathrm{dd}, J=13.8,7.4,1 \mathrm{H}), 1.26-$ $1.07(\mathrm{~m}, 5 \mathrm{H}), 0.64(\mathrm{dt}, J=7.4 \mathrm{~Hz}, 3 \mathrm{H})$. HRMS found for $\mathrm{M}^{+}+1,295.1916, \mathrm{C}_{18} \mathrm{H}_{23} \mathrm{~N}_{4}$ requires 295.1917.

2-(3-(3-Chloro-1H-pyrazolo[3,4-b]pyridin-4-yl)phenyl)-2-methylbutan-1-amine (16). Step 1. 26 (100 mg, $0.358 \mathrm{mmol}), 60$ (139 mg, $0.358 \mathrm{mmol}), \mathrm{Na}_{2} \mathrm{CO}_{3}(2 \mathrm{M}, 1.07 \mathrm{mmol})$ and $\mathrm{Pd}\left(\mathrm{PPh}_{3}\right)_{4}$ (41.4 mg, $0.0358 \mathrm{mmol})$ were placed in a microwave tube and dioxane $(1 \mathrm{~mL})$ was added. The resulting suspension was stirred at $150{ }^{\circ} \mathrm{C}$ in the microwave for $45 \mathrm{~min}$. The reaction mixture was partitioned between ethyl acetate and brine. The aqueous layer was extracted with ethyl acetate (3 x $20 \mathrm{~mL})$ and the combined organics were dried $\left(\mathrm{Na}_{2} \mathrm{SO}_{4}\right)$, filtered and concentrated in vacuo. Purification by column chromatography (35\% ethyl acetate in hexanes) gave 61 (68.4 mg, 46\%) as a light yellow solid. ${ }^{1} \mathrm{H}$ NMR $\left(400 \mathrm{MHz}, \mathrm{DMSO}-d_{6}\right) \delta 14.08(\mathrm{~s}, 1 \mathrm{H}), 8.62(\mathrm{~d}, J=4.8 \mathrm{~Hz}, 1 \mathrm{H})$, 7.50-7.42 (m, 4H), 7.21 (d, $J=4.8 \mathrm{~Hz}, 1 \mathrm{H}), 6.61(\mathrm{t}, J=6.0 \mathrm{~Hz}, 1 \mathrm{H}), 3.35-3.25(\mathrm{~m}, 1 \mathrm{H}), 3.21-3.16$ $(\mathrm{m}, 1 \mathrm{H}), 1.80-1.70(\mathrm{~m}, 1 \mathrm{H}), 1.60-1.50(\mathrm{~m}, 1 \mathrm{H}), 1.24(\mathrm{~s}, 9 \mathrm{H}), 1.23(\mathrm{~s}, 3 \mathrm{H}), 0.62(\mathrm{t}, J=7.2 \mathrm{~Hz}$, $3 \mathrm{H})$. LRMS found for $\mathrm{M}^{+}+1,415.3 . \mathrm{C}_{22} \mathrm{H}_{28} \mathrm{CIN}_{4} \mathrm{O}_{2}$ requires 415.19 .

Step 2. 61 (60 mg, $0.145 \mathrm{mmol})$ was dissolved in dry DCM (2 mL) and cooled in an ice-bath. TFA $(2 \mathrm{~mL})$ was added slowly dropwise and the resultant mixture was stirred at $0{ }^{\circ} \mathrm{C}$ for $25 \mathrm{~min}$ and at room temperature for $45 \mathrm{~min}$. The reaction mixture was concentrated in vacuo and partitioned between ethyl acetate and saturated aqueous $\mathrm{Na}_{2} \mathrm{CO}_{3}$. The aqueous layer was extracted with ethyl acetate $(3 \times 10 \mathrm{~mL})$ and the combined organics were dried $\left(\mathrm{Na}_{2} \mathrm{SO}_{4}\right)$, filtered and concentrated in vacuo. The resulting mixture was purified by column chromatography $(9 \%$ $\mathrm{MeOH} / 1 \% \mathrm{NH}_{4} \mathrm{OH}$ in DCM) to give $\mathbf{1 6}(14.6 \mathrm{mg}, 32 \%)$ as an off white solid. ${ }^{1} \mathrm{H}$ NMR (400 MHz, DMSO- $\left.d_{6}\right) \delta 8.62(\mathrm{~d}, J=4.6 \mathrm{~Hz}, 1 \mathrm{H}), 7.51-7.40(\mathrm{~m}, 4 \mathrm{H}), 7.22(\mathrm{~d}, J=4.8 \mathrm{~Hz}, 1 \mathrm{H}), 2.82(\mathrm{~d}$, $J=12.8 \mathrm{~Hz}, 1 \mathrm{H}), 2.65(\mathrm{~d}, J=12.9 \mathrm{~Hz}, 1 \mathrm{H}), 1.79(\mathrm{dd}, J=7.4,13.8 \mathrm{~Hz}, 1 \mathrm{H}), 1.56(\mathrm{dd}, J=7.4$, $13.8 \mathrm{~Hz}, 1 \mathrm{H}), 1.27(\mathrm{~s}, 3 \mathrm{H}), 0.64(\mathrm{t}, J=7.4 \mathrm{~Hz}, 3 \mathrm{H})$. HRMS found for $\mathrm{M}^{+}+1,315.1370$, $\mathrm{C}_{17} \mathrm{H}_{20} \mathrm{ClN}_{4}$ requires 315.1371 .

2-Methyl-2-(3-(3-(trifluoromethyl)-1H-pyrazolo[3,4-b]pyridin-4-yl)phenyl)butan-1-amine (17). Step 1. To a mixture of diisopropylamine $(2.61 \mathrm{~g}, 25.8 \mathrm{mmol})$ in THF $(19 \mathrm{~mL})$ at $-70{ }^{\circ} \mathrm{C}$ 
was added $\mathrm{n}-\mathrm{BuLi}(2.5 \mathrm{M}, 24.7 \mathrm{mmol})$ dropwise and the resulting mixture stirred at $0{ }^{\circ} \mathrm{C}$ for 2 min. The mixture was re-cooled to $-70^{\circ} \mathrm{C}$ and a solution of 2-fluoro-3-iodo-pyridine $(5 \mathrm{~g}, 22.4$ $\mathrm{mmol})$ in THF $(14 \mathrm{~mL})$ was added slowly dropwise and the resulting mixture stirred at $-70{ }^{\circ} \mathrm{C}$ for 2 h. 2,2,2-trifluoroacetaldehyde was added via cannula and the resultant mixture was stirred at $70{ }^{\circ} \mathrm{C}$ for $1 \mathrm{~h}$. The reaction was quenched at $-70{ }^{\circ} \mathrm{C}$ by addition of water $(40 \mathrm{~mL})$ and extracted with ethyl acetate $(3 \times 50 \mathrm{~mL})$ and the combined organics dried $\left(\mathrm{Na}_{2} \mathrm{SO}_{4}\right)$, filtered and concentrated in vacuo. Purification by column chromatography ( $5 \%$ ethyl acetate in DCM) gave $32(1.61 \mathrm{~g}, 22 \%)$ as an orange solid. ${ }^{1} \mathrm{H}$ NMR $\left(400 \mathrm{MHz}, \mathrm{DMSO}-d_{6}\right) \delta 7.98-7.93(\mathrm{~m}, 2 \mathrm{H}), 7.25$ $(\mathrm{d}, J=6.0 \mathrm{~Hz}, 1 \mathrm{H}), 5.53-5.46(\mathrm{~m}, 1 \mathrm{H}) .{ }^{19} \mathrm{~F}$ NMR $\left(400 \mathrm{MHz}, \mathrm{DMSO}-d_{6}\right) \delta-62.2,-74.8$. LRMS found for $\mathrm{M}^{+}+1,321.8, \mathrm{C}_{7} \mathrm{H}_{5} \mathrm{~F}_{4} \mathrm{INO}$ requires 321.94 .

Step 2. 32 (1.59 g, $4.95 \mathrm{mmol})$ was dissolved in toluene (40 mL) and $\mathrm{MnO}_{2}(5.06 \mathrm{~g}, 49.5 \mathrm{mmol})$ was added in one portion. The resultant suspension was stirred at reflux for $30 \mathrm{~min}$. The reaction mixture was cooled to RT, filtered through Celite washing copiously with ethyl acetate and the combined filtrate was concentrated in vacuo. Purification by column chromatography $(10 \%$ ethyl acetate in hexanes) gave 34 as a light yellow oil (1.08 g, 68\%). ${ }^{1} \mathrm{H}$ NMR (400 MHz, DMSO- $\left.d_{6}\right) \delta$ $8.24(\mathrm{~d}, J=5.2 \mathrm{~Hz}, 1 \mathrm{H}), 8.16(\mathrm{dd}, J=1.0,5.2 \mathrm{~Hz}, 1 \mathrm{H}) .{ }^{19} \mathrm{~F}$ NMR $\left(400 \mathrm{MHz}, \mathrm{DMSO}-d_{6}\right) \delta-64.5$, 75.4. LRMS found for $\mathrm{M}^{+}+1,319.9, \mathrm{C}_{7} \mathrm{H}_{3} \mathrm{FINO}$ requires 319.92 .

Step 3. $34(1.07 \mathrm{~g}, 3.36 \mathrm{mmol})$ was dissolved in dioxane $(10 \mathrm{~mL})$ and hydrazine monohydrate $(505 \mathrm{mg}, 10.1 \mathrm{mmol})$ was added in one portion. The resulting mixture was stirred at $90{ }^{\circ} \mathrm{C}$ for 30 min, allowed to cool to RT and partitioned between ethyl acetate and brine. The aqueous layer was extracted with ethyl acetate $(3 \times 50 \mathrm{~mL})$ and the combined organics were dried $\left(\mathrm{Na}_{2} \mathrm{SO}_{4}\right)$, filtered and concentrated in vacuo. Purification by column chromatography (30\% ethyl acetate in hexanes) followed by trituration with DCM gave 36 (707 mg, 67\%) as a white solid. ${ }^{1} \mathrm{H}$ NMR $\left(400 \mathrm{MHz}, \mathrm{DMSO}-d_{6}\right) \delta 14.8(\mathrm{br} \mathrm{s}, 1 \mathrm{H}), 8.28(\mathrm{~d}, J=4.8 \mathrm{~Hz}, 1 \mathrm{H}), 7.97(\mathrm{~d}, J=4.8 \mathrm{~Hz}, 1 \mathrm{H}) .{ }^{19} \mathrm{~F}$ NMR (400 MHz, DMSO- $\left.d_{6}\right) \delta$-55.3. LRMS found for $\mathrm{M}^{+}+1,313.9, \mathrm{C}_{7} \mathrm{H}_{4} \mathrm{~F}_{3} \mathrm{IN} \mathrm{N}_{3}$ requires 313.94.

Step 4. 36 (100 mg, $0.320 \mathrm{mmol})$ was dissolved in DMF $(1 \mathrm{~mL})$ and cooled in an ice-bath. Sodium hydride $(14.1 \mathrm{mg}, 0.352 \mathrm{mmol}$ ) was added in one portion and the resulting mixture was stirred at $0{ }^{\circ} \mathrm{C}$ for $15 \mathrm{~min}$. Trityl chloride $(93.5 \mathrm{mg}, 0.336 \mathrm{mmol})$ was added in one portion and the resulting light yellow solution stirred at RT for $2 \mathrm{~h}$ and then concentrated under reduced pressure. This material was partitioned between ethyl acetate and brine and the organic layer was washed with brine, dried $\left(\mathrm{Na}_{2} \mathrm{SO}_{4}\right)$, filtered and concentrated in vacuo. Purification by column chromatography (5-10\% ethyl acetate in hexanes) gave 37 as a white solid $(164 \mathrm{mg}, 93 \%) .{ }^{1} \mathrm{H}$ NMR $\left(400 \mathrm{MHz}, \mathrm{DMSO}-d_{6}\right) \delta 8.00(\mathrm{~d}, J=4.8 \mathrm{~Hz}, 1 \mathrm{H}), 7.93(\mathrm{~d}, J=4.8 \mathrm{~Hz}, 1 \mathrm{H}), 7.36-7.28(\mathrm{~m}$, 9H), 7.22-7.19 (m, 6H). ${ }^{19} \mathrm{~F}$ NMR (400 MHz, DMSO- $\left.d_{6}\right) \delta$-55.1. LRMS found for $\mathrm{M}^{+}+1,556.2$, $\mathrm{C}_{26} \mathrm{H}_{18} \mathrm{~F}_{3} \mathrm{IN}_{3}$ requires 556.05 .

Step 5. 37 (135 mg, $0.243 \mathrm{mmol})$ and $\mathbf{6 0}(94.7 \mathrm{mg}, 0.243 \mathrm{mmol})$ were dissolved in dry Dioxane (1 $\mathrm{mL})$ and $\mathrm{Na}_{2} \mathrm{CO}_{3}(2 \mathrm{M}, 0.729 \mathrm{mmol})$ was added. The solution was degassed (vacuum / nitrogen cycles $x$ 5) and $\mathrm{Pd}\left[\mathrm{P}(\mathrm{tBu})_{3}\right]_{2}(12.4 \mathrm{mg}, 0.0243 \mathrm{mmol})$ was added and the mixture stirred at $60{ }^{\circ} \mathrm{C}$ overnight. The reaction was allowed to cool to RT and partitioned between ethyl acetate and saturated aq. $\mathrm{Na}_{2} \mathrm{CO}_{3}$. The aqueous layer was extracted with ethyl acetate $(3 \times 10 \mathrm{~mL})$ and the combined organics dried $\left(\mathrm{Na}_{2} \mathrm{SO}_{4}\right)$, filtered and concentrated in vacuo. Purification by column chromatography (15\% ethyl acetate in hexanes) gave $\mathbf{6 2}(152 \mathrm{mg}, 90 \%)$ as a light brown solid. ${ }^{1} \mathrm{H}$ NMR (400 MHz, DMSO- $\left.d_{6}\right) \delta 8.38(\mathrm{~d}, J=4.8 \mathrm{~Hz}, 1 \mathrm{H}), 7.44(\mathrm{~d}, J=4.0 \mathrm{~Hz}, 2 \mathrm{H}), 7.40-7.14(\mathrm{~m}$, $18 \mathrm{H}), 6.55-6.52(\mathrm{~m}, 1 \mathrm{H}), 3.30-3.20(\mathrm{~m}, 1 \mathrm{H}), 3.20-3.10(\mathrm{~m}, 1 \mathrm{H}), 1.78-1.66(\mathrm{~m}, 1 \mathrm{H}), 1.60-1.49(\mathrm{~m}$, $1 \mathrm{H}), 1.30(\mathrm{~s}, 9 \mathrm{H}), 1.23(\mathrm{~s}, 3 \mathrm{H}), 0.58(\mathrm{t}, J=7.2 \mathrm{~Hz}, 3 \mathrm{H}) .{ }^{19} \mathrm{~F}$ NMR (400 MHz, DMSO- $\left.d_{6},\right) \delta-57.9$. Mass spectrum (ESI) $m / z 691.5[\mathrm{M}+\mathrm{H}]^{+}$.

Step 6. 62 (148 mg, $0.214 \mathrm{mmol})$ was dissolved in dry DCM (2 mL) and cooled in an ice-bath. Triethylsilane $(99.6 \mathrm{mg}, 0.857 \mathrm{mmol})$ was added followed slowly dropwise by TFA $(2 \mathrm{~mL})$. The 
resulting mixture was stirred at $0{ }^{\circ} \mathrm{C}$ for $2 \mathrm{~h}$. The reaction mixture was concentrated in vacuo and then partitioned between ether and brine. The ether layer was washed with $1 \mathrm{M} \mathrm{HCl}(2 \times 10 \mathrm{~mL})$ and the combined aqueous layers was basified with saturated aq. $\mathrm{NaHCO}_{3}$ and extracted with ethyl acetate $(3 \times 10 \mathrm{~mL})$. The combined ethyl acetate was dried over $\mathrm{Na}_{2} \mathrm{SO}_{4}$, filtered and concentrated in vacuo. Purification by column chromatography $\left(4.5 \% \mathrm{MeOH} / 0.5 \% \mathrm{NH}_{4} \mathrm{OH}\right.$ in DCM) gave $17(11 \mathrm{mg}, 15 \%)$ as a white powder. ${ }^{1} \mathrm{H}$ NMR (DMSO- $\left.d_{6}, 400 \mathrm{MHz}\right) \delta 8.74(\mathrm{~d}, J=$ $4.8 \mathrm{~Hz}, 1 \mathrm{H}), 7.57-7.51(\mathrm{~m}, 2 \mathrm{H}), 7.40(\mathrm{~s}, 1 \mathrm{H}), 7.34(\mathrm{~d}, J=6.0 \mathrm{~Hz}, 1 \mathrm{H}), 7.30(\mathrm{~d}, J=4.8 \mathrm{~Hz}, 1 \mathrm{H})$, 5.89 (br s, 2H), 2.87 (d, $J=12.8 \mathrm{~Hz}, 1 \mathrm{H}), 2.71$ (d, $J=12.8 \mathrm{~Hz}, 1 \mathrm{H}), 1.87-1.79$ (m, 1H), 1.64-1.55 $(\mathrm{m}, 1 \mathrm{H}), 1.31(\mathrm{~s}, 3 \mathrm{H}), 0.70(\mathrm{t}, J=7.2 \mathrm{~Hz}, 3 \mathrm{H}) .{ }^{19} \mathrm{~F}$ NMR $\left(400 \mathrm{MHz}, \mathrm{DMSO}-d_{6}\right) \delta-57.8$. HRMS found for $\mathrm{M}^{+}+1,349.1637, \mathrm{C}_{18} \mathrm{H}_{20} \mathrm{~F}_{3} \mathrm{~N}_{4}$ requires 349.1635 .

\section{(1-(3-Methyl-5-(3-(trifluoromethyl)-1H-pyrazolo[3,4-b]pyridin-4-}

yl)phenyl)cyclobutyl)methanamine (18). Step 1. Sodium hydride (60\% in mineral oil, $4.16 \mathrm{~g}$, $104 \mathrm{mmol})$ was added portionwise over $10 \mathrm{~min}$ to a solution of $\mathbf{6 8}(13 \mathrm{~g}, 47.3 \mathrm{mmol})$ in DMSO $(100 \mathrm{~mL})$ at RT. The reaction was stirred at RT for $40 \mathrm{~min}$ then 1,3-dibromopropane $(10.0 \mathrm{~g}, 49.6$ mmol) was added dropwise with ice-bath cooling. After stirring the mixture for $20 \mathrm{~min}$ at RT, the reaction was cooled on an ice-bath and carefully quenched by addition of water $(250 \mathrm{~mL})$ and ethyl acetate/toluene $(375 \mathrm{~mL}, 2: 1)$. The organic layer was separated and the aqueous layer further extracted with ethyl acetate/toluene $(2 \times 375 \mathrm{~mL}, 2: 1)$. The combined organics were washed with $2 \mathrm{M} \mathrm{HCl}(200 \mathrm{~mL})$, water $(3 \times 200 \mathrm{~mL})$, brine $(200 \mathrm{~mL})$, dried $\left(\mathrm{MgSO}_{4}\right)$, filtered and concentrated in vacuo. The crude product was purified by column chromatography (330 g, 0$15 \%$ ethyl acetate/petroleum ether) to give $77(8 \mathrm{~g}, 54 \%)$ as an off-white solid. ${ }^{1} \mathrm{H}$ NMR (400 MHz, DMSO- $\left.d_{6}\right) \delta 7.87(\mathrm{~s}, 1 \mathrm{H}), 7.69(\mathrm{~s}, 2 \mathrm{H}), 2.76-2.61(\mathrm{~m}, 4 \mathrm{H}), 2.29-2.22(\mathrm{~m}, 1 \mathrm{H}), 2.01-1.94$ $(\mathrm{m}, 1 \mathrm{H})$.

Step 2. 77 (1 g, $3.18 \mathrm{mmol})$ was dissolved in THF (5 mL) and $\mathrm{PdCl}_{2}(\mathrm{dppf})_{2} \cdot \mathrm{CH}_{2} \mathrm{Cl}_{2}(130 \mathrm{mg}$, $0.159 \mathrm{mmol}$ ) was added followed by $\mathrm{CuI}(36.3 \mathrm{mg}, 0.191 \mathrm{mmol})$. Chloromethylzinc (2M in THF, $3.49 \mathrm{mmol}$ ) was added and the mixture immediately heated at $150^{\circ} \mathrm{C}$ for $10 \mathrm{~min}$ in the microwave at a fixed power of $300 \mathrm{~W}$. The reaction mixture was diluted with ethyl acetate, washed with water, brine, dried $\left(\mathrm{MgSO}_{4}\right)$, filtered and concentrated in vacuo. Purification by column chromatography ( $80 \mathrm{~g}, 1-20 \%$ ethyl acetate/petroleum ether) gave $\mathbf{7 8}(550 \mathrm{mg}, 69 \%)$ as an off white solid. ${ }^{1} \mathrm{H}$ NMR $\left(400 \mathrm{MHz}, \mathrm{CDCl}_{3}\right) \delta 7.36(\mathrm{~s}, 1 \mathrm{H}), 7.31(\mathrm{~s}, 1 \mathrm{H}), 7.16(\mathrm{~s}, 1 \mathrm{H}), 2.86-$ $2.80(\mathrm{~m}, 2 \mathrm{H}), 2.65-2.58(\mathrm{~m}, 2 \mathrm{H}), 2.49-2.42(\mathrm{~m}, 1 \mathrm{H}), 2.38(\mathrm{~s}, 3 \mathrm{H}), 2.13-2.07(\mathrm{~m}, 1 \mathrm{H})$.

Step 3. To a solution of $78(1.28 \mathrm{~g}, 5.12 \mathrm{mmol})$ in dioxane $(20 \mathrm{~mL})$ was added bis(pinacolato)diboron $(1.56 \mathrm{~g}, 6.14 \mathrm{mmol})$ and potassium acetate $(1.51 \mathrm{~g}, 15.4 \mathrm{mmol})$ and the reaction evacuated and filled with nitrogen 5 times before $\mathrm{Pd}(\mathrm{dppf}) \mathrm{Cl}_{2} \cdot \mathrm{CH}_{2} \mathrm{Cl}_{2}(209 \mathrm{mg}, 0.256$ mmol) was added. The reaction was heated under reflux for $4 \mathrm{~h}$ at $90{ }^{\circ} \mathrm{C}$ then allowed to cool to ambient temperature and diluted with ethyl acetate. The organic layer was washed with brine, dried $\left(\mathrm{MgSO}_{4}\right)$, filtered and concentrated in vacuo. Purification by column chromatography $(80 \mathrm{~g}$, $2.5-40 \%$ ethyl acetate/petroleum ether) gave $79(1 \mathrm{~g}, 66 \%)$ as an off white solid. ${ }^{1} \mathrm{H}$ NMR (400 $\left.\mathrm{MHz}, \mathrm{CDCl}_{3}\right) \delta 7.61(\mathrm{~s}, 1 \mathrm{H}), 7.57(\mathrm{~s}, 1 \mathrm{H}), 7.29(\mathrm{~s}, 1 \mathrm{H}), 2.83-2.77(\mathrm{~m}, 2 \mathrm{H}), 2.69-2.64(\mathrm{~m}, 2 \mathrm{H})$, 2.44-2.37 (m, 1H), $2.37(\mathrm{~s}, 3 \mathrm{H}), 2.07-2.04(\mathrm{~m}, 1 \mathrm{H})$. LRMS found for $\mathrm{M}^{+}+1,298.3$, $\mathrm{C}_{18} \mathrm{H}_{25} \mathrm{BNO}_{2}$ requires 298.20.

Step 4. 79 (1 g, $3.37 \mathrm{mmol})$ was dissolved in dioxane $(20 \mathrm{~mL})$ and $41(1.87 \mathrm{~g}, 3.37 \mathrm{mmol})$ was added followed by $\mathrm{Na}_{2} \mathrm{CO}_{3}(2 \mathrm{M}, 10.1 \mathrm{mmol})$. The reaction mixture was degassed (vacuum/nitrogen cycling five times) before $\mathrm{Pd}\left[\mathrm{P}(\mathrm{tBu})_{3}\right]_{2}(258 \mathrm{mg}, 0.505 \mathrm{mmol})$ was added. After heating overnight at $60^{\circ} \mathrm{C}$ the reaction was allowed to cool and water and ethyl acetate were added. The mixture was extracted with ethyl acetate (x3) and the combined organics washed with brine, dried $\left(\mathrm{MgSO}_{4}\right)$, filtered and concentrated in vacuo. Purification by column chromatography (120 g, 2.5-40\% ethyl acetate/petroleum ether) gave $80(1.88 \mathrm{~g}, 93 \%)$ as an off white solid. ${ }^{1} \mathrm{H}$ 
$\operatorname{NMR}\left(400 \mathrm{MHz}, \mathrm{CDCl}_{3}\right) \delta 8.31(\mathrm{~d}, J=4.6 \mathrm{~Hz}, 1 \mathrm{H}), 7.34-7.23(\mathrm{~m}, 18 \mathrm{H}), 7.04(\mathrm{~d}, J=4.6 \mathrm{~Hz}, 1 \mathrm{H})$, 2.88-2.81 (m, 2H), 2.73-2.65 (m, 2H), 2.50-2.43 (m, 1H), 2.46 (s, 3H), 2.14-2.07 (m, $1 \mathrm{H}) ;{ }^{19} \mathrm{~F}$ NMR $\left(400 \mathrm{MHz}, \mathrm{CDCl}_{3}\right) \delta$-59.1. LRMS found for $\mathrm{M}^{+}+1,599.2, \mathrm{C}_{38} \mathrm{H}_{30} \mathrm{~F}_{3} \mathrm{~N}_{4}$ requires 599.24

Step 5. To a solution of $\mathbf{8 0}(1.88 \mathrm{~g}, 3.14 \mathrm{mmol})$ in THF $(35 \mathrm{~mL})$ at $0{ }^{\circ} \mathrm{C}$ was added alane:dimethylethylamine $(0.5 \mathrm{M}$ in toluene, $12.6 \mathrm{mmol})$ dropwise and the reaction allowed to warm to rt overnight. The reaction was quenched by the slow addition of water/THF $(1: 1,15 \mathrm{~mL})$ and the resulting suspension was stirred vigorously for $5 \mathrm{~min}$ and filtered through Celite. The collected solid was washed copiously with ethyl acetate/water and extracted with ethyl acetate. The combined organics were washed with brine, dried $\left(\mathrm{MgSO}_{4}\right)$, filtered and concentrated in vacuo. Purification by column chromatography (120 g, 0-10\% MeOH in DCM) gave 81 (1.61 g, $85 \%)$ as an off white solid. ${ }^{1} \mathrm{H}$ NMR $\left(400 \mathrm{MHz}, \mathrm{CDCl}_{3}\right) \delta 8.29(\mathrm{~d}, J=4.6 \mathrm{~Hz}, 1 \mathrm{H}), 7.32-7.24(\mathrm{~m}$, 15H), 7.10-7.00 (m, 4H), 2.99 (s, 2H), 2.43 (s, 3H), 2.42-2.35 (m, 2H), 2.17-2.07 (m, 3H), 1.93$1.90(\mathrm{~m}, 1 \mathrm{H}) .{ }^{19} \mathrm{~F}$ NMR $\left(400 \mathrm{MHz}, \mathrm{CDCl}_{3}\right) \delta-59.1$. LRMS found for $\mathrm{M}^{+}+1,603.3, \mathrm{C}_{38} \mathrm{H}_{34} \mathrm{~F}_{3} \mathrm{~N}_{4}$ requires 603.28 .

Step 6. To a solution of $81(1.61 \mathrm{~g}, 2.67 \mathrm{mmol})$ in $\mathrm{DCM}(35 \mathrm{~mL})$ at $0{ }^{\circ} \mathrm{C}$ was added triethylsilane $(1.24 \mathrm{~g}, 10.7 \mathrm{mmol})$ followed by TFA $(5 \mathrm{~mL})$ and the reaction warmed slowly overnight to $10^{\circ} \mathrm{C}$. The reaction mixture was concentrated in vacuo then partitioned between saturated aq. $\mathrm{NaHCO}_{3}$ and ethyl acetate. The aqueous layer was re-extracted with ethyl acetate and the combined organics washed with brine, dried $\left(\mathrm{MgSO}_{4}\right)$, filtered and concentrated in vacuo. Purification by column chromatography (40 g, $1-10 \% \mathrm{MeOH}$ [containing 10\% $\mathrm{NH}_{4} \mathrm{OH}$ ]/DCM) gave 18 (473 mg, $48 \%)$ as a colorless foam. ${ }^{1} \mathrm{H}$ NMR $\left(400 \mathrm{MHz}, \mathrm{DMSO}-d_{6}\right) \delta 8.66(\mathrm{~d}, J=4.6 \mathrm{~Hz}, 1 \mathrm{H}), 7.24(\mathrm{~d}, J=$ 4.6 Hz, 1H), 7.09 (s, 1H), $7.04(\mathrm{~s}, 1 \mathrm{H}), 6.95(\mathrm{~s}, 1 \mathrm{H}), 5.75$ (br s, 2H), $2.75(\mathrm{~m}, 2 \mathrm{H}), 2.35(\mathrm{~s}, 3 \mathrm{H})$, 2.25-2.03 (m, 5H), 2.01-1.95 (m, 1H), 1.82-1.77 (m, 1H). ${ }^{19} \mathrm{~F}$ NMR (400 MHz, DMSO- $\left.d_{6}\right) \delta-$ 57.7. HRMS found for $\mathrm{M}^{+}+1,361.1633, \mathrm{C}_{19} \mathrm{H}_{20} \mathrm{~F}_{3} \mathrm{~N}_{4}$ requires 361.1635 .

(1-(3-(3-(Trifluoromethyl)-1H-pyrazolo[3,4-b]pyridin-4-yl)phenyl)cyclobutyl)methanamine (19). Step 1. 38 (300 mg, $1.27 \mathrm{mmol})$, bis(pinacolato)diboron (387 mg, $1.53 \mathrm{mmol})$ and potassium acetate $(374 \mathrm{mg}, 3.81 \mathrm{mmol})$ were dissolved in dioxane $(4 \mathrm{~mL})$. The resultant mixture was degassed and filled with nitrogen three times. $\mathrm{Pd}(\mathrm{dppf}) \mathrm{Cl}_{2} . \mathrm{DCM}(52 \mathrm{mg}, 0.064 \mathrm{mmol})$ was then added and the reaction heated at $90{ }^{\circ} \mathrm{C}$ for $5 \mathrm{~h}$. The reaction mixture was diluted with ethyl acetate, washed with brine, dried $\left(\mathrm{MgSO}_{4}\right)$, filtered and concentrated in vacuo. Purification by column chromatography ( $40 \mathrm{~g}, 5-30 \%$ ethyl acetate/petroleum ether) gave $\mathbf{5 0}(245 \mathrm{mg}, 68 \%) .{ }^{1} \mathrm{H}$ NMR $\left(400 \mathrm{MHz}, \mathrm{CDCl}_{3}\right) \delta 7.84(\mathrm{~s}, 1 \mathrm{H}), 7.78(\mathrm{~d}, J=7.2 \mathrm{~Hz}, 1 \mathrm{H}), 7.53-7.50(\mathrm{~m}, 1 \mathrm{H}), 7.42(\mathrm{t}, J=$ $7.2 \mathrm{~Hz}, 1 \mathrm{H}), 2.87-2.82(\mathrm{~m}, 2 \mathrm{H}), 2.73-2.65(\mathrm{~m}, 2 \mathrm{H}), 2.48-2.45(\mathrm{~m}, 1 \mathrm{H}), 2.12-2.05(\mathrm{~m}, 1 \mathrm{H})$, $1.37(\mathrm{~s}, 12 \mathrm{H})$. LRMS found for $\mathrm{M}^{+}+1,284.2, \mathrm{C}_{17} \mathrm{H}_{23} \mathrm{BNO}_{2}$ requires 284.18.

Step 2. 50 (120 mg, $0.424 \mathrm{mmol})$ was dissolved in dioxane (4 mL) and 37 (196 mg, $0.353 \mathrm{mmol})$ was added followed by $\mathrm{Na}_{2} \mathrm{CO}_{3}(2 \mathrm{M}, 1.06 \mathrm{mmol})$. The mixture was vacuum/nitrogen cycled 5 times then $\mathrm{Pd}\left[\mathrm{P}(\mathrm{tBu})_{3}\right]_{2}(27 \mathrm{mg}, 0.053 \mathrm{mmol})$ was added. The reaction was heated overnight at 60 ${ }^{\circ} \mathrm{C}$ then allowed to cool. Water and ethyl acetate were added. The mixture was extracted three times with ethyl acetate and the combined organics washed with brine, dried $\left(\mathrm{MgSO}_{4}\right)$, filtered and concentrated in vacuo. Purification by column chromatography ( $24 \mathrm{~g}, 2.5-40 \%$ ethyl acetate /petroleum ether) gave 51 (165 mg, 80\%). ${ }^{1} \mathrm{H}$ NMR $\left(400 \mathrm{MHz}, \mathrm{CDCl}_{3}\right) \delta 8.32(\mathrm{~d}, J=4.6 \mathrm{~Hz}, 1 \mathrm{H})$, $7.55-7.51(\mathrm{~m}, 3 \mathrm{H}), 7.32-7.30(\mathrm{~m}, 1 \mathrm{H}), 7.28-7.23(\mathrm{~m}, 15 \mathrm{H}), 7.04(\mathrm{~d}, J=4.6 \mathrm{~Hz}, 1 \mathrm{H}), 2.86-$ $2.80(\mathrm{~m}, 2 \mathrm{H}), 2.72-2.66(\mathrm{~m}, 2 \mathrm{H}), 2.50-2.45(\mathrm{~m}, 1 \mathrm{H}), 2.12-2.06(\mathrm{~m}, 1 \mathrm{H})$. LRMS found for $\mathrm{M}^{+}$ $+1,585.4, \mathrm{C}_{37} \mathrm{H}_{28} \mathrm{~F}_{3} \mathrm{~N}_{4}$ requires 585.23.

Step 3. 51 (100 mg, $0.171 \mathrm{mmol})$ was dissolved in THF $(3 \mathrm{~mL})$ and cooled to $0{ }^{\circ} \mathrm{C}$. Alane:N,Ndimethylethanamine $(0.5 \mathrm{M}, 0.684 \mathrm{mmol})$ was added and the reaction mixture allowed to warm to RT overnight. The reaction was quenched by the slow addition of $1: 1$ water:THF $(\sim 5 \mathrm{~mL})$. The resulting suspension was stirred vigorously for $5 \mathrm{~min}$ and filtered through Celite. The collected solid was washed copiously with ethyl acetate/water and extracted with ethyl acetate. The 
combined organics were washed with brine, dried $\left(\mathrm{MgSO}_{4}\right)$, filtered and concentrated in vacuo. Purification by column chromatography (12 g, 0-10\% MeOH:DCM) gave 52 (88 mg, 87\%). LRMS found for $\mathrm{M}^{+}+1,589.3, \mathrm{C}_{37} \mathrm{H}_{32} \mathrm{~F}_{3} \mathrm{~N}_{4}$ requires 589.26.

Step 4. $52(88 \mathrm{mg}, 0.150 \mathrm{mmol})$ was dissolved in DCM (3 mL) and cooled to $0{ }^{\circ} \mathrm{C}$. Triethylsilane (70 $\mathrm{mg}, 0.598 \mathrm{mmol})$ was added followed by TFA $(0.5 \mathrm{~mL})$. The reaction was stirred for $1 \mathrm{~h}$ at 0 ${ }^{\circ} \mathrm{C}$. The solvent was removed under reduced pressure. The residue was purified by Fractionlynx prep LCMS (aq. TFA/MeCN) and the pure fractions passed through as SPE bicarbonate cartridge and lyophilized to give 19 (23 mg, 43\%). ${ }^{1} \mathrm{H}$ NMR (DMSO- $\left.d_{6}, 400 \mathrm{MHz}\right) \delta 8.68(\mathrm{~d}, 1 \mathrm{H}, \mathrm{J}=4.6$ $\mathrm{Hz}, 1 \mathrm{H}), 7.43-7.47(\mathrm{~m}, 1 \mathrm{H}), 7.20$ - $7.28(\mathrm{~m}, 3 \mathrm{H}), 7.16(\mathrm{~s}, 1 \mathrm{H}), 2.82(\mathrm{~s}, 2 \mathrm{H}), 2.14-2.26(\mathrm{~m}, 4 \mathrm{H})$, 1.97 - $2.04(\mathrm{~m}, 1 \mathrm{H}), 1.75-1.83(\mathrm{~m}, 1 \mathrm{H})$. HRMS found for $\mathrm{M}^{+}+1,347.1477, \mathrm{C}_{18} \mathrm{H}_{18} \mathrm{~F}_{3} \mathrm{~N}_{4}$ requires 347.1478 .

(4-(3-Methyl-5-(3-(trifluoromethyl)-1 $H$-pyrazolo[3,4-b]pyridin-4-yl)phenyl)tetrahydro-2 $H$ pyran-4-yl)methanamine (20). Step 1. To a solution of 41 (2 g, $7.52 \mathrm{mmol})$ in THF (30 mL) @ $0{ }^{\circ} \mathrm{C}$ was slowly added alane:dimethylethylamine complex $(0.5 \mathrm{M}$ in toluene, $22.5 \mathrm{mmol})$ over a 10 min period giving a red solution. After complete addition, the mixture was stirred at $0{ }^{\circ} \mathrm{C}$ for a further 20 min then stirred at RT overnight. The reaction mixture was very carefully quenched by the slow addition of THF/water $(1: 1,30 \mathrm{~mL})$. Once added, the mixture was stirred rapidly for 5 min then filtered through a pad of Celite, washing through with copious amounts of ethyl acetate. The filtrate was then washed with small amount of brine and dried $\left(\mathrm{MgSO}_{4}\right)$, filtered and concentrated in vacuo. Purification by column chromatography (80 g, 0-5\% MeOH:DCM) gave $87(1.8 \mathrm{~g}, 89 \%)$ as an orange oil. ${ }^{1} \mathrm{H}$ NMR (DMSO- $\left.d_{6}, 400 \mathrm{MHz}\right) \delta 7.47$ (t, $\left.J=1.6 \mathrm{~Hz}, 1 \mathrm{H}\right), 2.42$ $(\mathrm{dt}, J=7.2$ and $1.6 \mathrm{~Hz}, 1 \mathrm{H}), 7.35-7.29(\mathrm{~m}, 2 \mathrm{H}), 3.69-3.64(\mathrm{~m}, 2 \mathrm{H}), 3.38-3.33(\mathrm{~m}, 2 \mathrm{H}), 2.64$ (s, 2H), $2.00-1.95(\mathrm{~m}, 2 \mathrm{H}), 1.82-1.76(\mathrm{~m}, 2 \mathrm{H}), 1.01$ (br s, 2H). LRMS found for $\mathrm{M}^{+}+1,272.1$, $\mathrm{C}_{12} \mathrm{H}_{17} \mathrm{BrNO}$ requires 270.05 .

Step 2. To a solution of $87(1.8 \mathrm{~g}, 6.66 \mathrm{mmol})$ in THF $(16 \mathrm{~mL})$ and water $(4 \mathrm{~mL})$ was added $\mathrm{NaHCO}_{3}(1.68 \mathrm{~g}, 20.0 \mathrm{mmol})$. The resulting mixture was cooled to $0{ }^{\circ} \mathrm{C}$ before di-tert-butyl dicarbonate $(1.53 \mathrm{~g}, 7.00 \mathrm{mmol})$ was added in one portion. The reaction mixture was stirred at 0 ${ }^{\circ} \mathrm{C}$ for 30 min and at RT overnight. The reaction mixture was partitoned between ethyl acetate and a small amount of water. The organic layer was collected, washed with brine, dried $\left(\mathrm{MgSO}_{4}\right)$, filtered and concentrated in vacuo. Purification by column chromatography ( $80 \mathrm{~g}, 0-100 \%$ ethyl acetate/petroleum ether) gave $\mathbf{8 8}(2.32 \mathrm{~g}, 94 \%)$ as a white foam. ${ }^{1} \mathrm{H}$ NMR (DMSO- $d_{6}, 400 \mathrm{MHz}$ ) $\delta 7.44-7.39(\mathrm{~m}, 2 \mathrm{H}), 7.32-7.28(\mathrm{~m}, 2 \mathrm{H}), 6.77-6.75(\mathrm{~m}, 1 \mathrm{H}), 3.71-3.66(\mathrm{~m}, 2 \mathrm{H}), 3.37-3.30$ $(\mathrm{m}, 2 \mathrm{H}), 3.11-3.07(\mathrm{~m}, 2 \mathrm{H}), 1.99-1.94(\mathrm{~m}, 2 \mathrm{H}), 1.79-1.74(\mathrm{~m}, 2 \mathrm{H}), 1.28(\mathrm{~s}, 9 \mathrm{H})$. LRMS found for $\mathrm{M}^{+}+1,372.1, \mathrm{C}_{17} \mathrm{H}_{25} \mathrm{BrNO}_{3}$ requires 370.10 .

Step 3. Pd(OAc) 2 (28.1 mg, $0.125 \mathrm{mmol})$ and 2-(dicyclohexylphosphino)biphenyl (44 mg, 0.125 mmol) in 1,4-dioxane (15 mL) were stirred @ RT for 30 mins under nitrogen. Triethylamine $(1.90 \mathrm{~g}, 18.8 \mathrm{mmol})$, a solution of $\mathbf{8 8}(2.32 \mathrm{~g}, 6.266 \mathrm{mmol})$ in 1,4-dioxane (15 $\mathrm{mL})$ followed by 4,4,5,5-tetramethyl-1,3,2-dioxaborolane $(962 \mathrm{mg}, 7.52 \mathrm{mmol}$ ) were added. The reaction mixture was heated at $80^{\circ} \mathrm{C}$ overnight. The reaction mixture was cooled to RT, filtered through Celite, washing through with copious amounts of Ethyl acetate. The filtrate was concentrated in vacuo and purification by column chromatography ( $80 \mathrm{~g}, 0-20 \%$ ethyl acetate/petroleum ether) gave 89 (890 mg, 34\%). ${ }^{1} \mathrm{H}$ NMR (DMSO- $\left.d_{6}, 400 \mathrm{MHz}\right) \delta 7.57-7.28(\mathrm{~m}, 4 \mathrm{H}), 6.77-6.71(\mathrm{~m}, 1 \mathrm{H}), 3.69$ $-3.66(\mathrm{~m}, 2 \mathrm{H}), 3.34-3.30(\mathrm{~m}, 2 \mathrm{H}), 3.10-3.03(\mathrm{~m}, 2 \mathrm{H}), 1.99-1.91(\mathrm{~m}, 2 \mathrm{H}), 1.83-1.74(\mathrm{~m}$, 
$2 \mathrm{H}), 1.28(\mathrm{~s}, 12 \mathrm{H}) .1 .17(\mathrm{~s}, 9 \mathrm{H})$. LRMS found for $\mathrm{M}^{+}+1,418.2, \mathrm{C}_{23} \mathrm{H}_{37} \mathrm{BNO}_{5}$ requires 418.28.

Step 4. 37 and 89 (261 mg, $0.432 \mathrm{mmol})$ were dissolved in dry dioxane (4 mL) and $\mathrm{Na}_{2} \mathrm{CO}_{3}(2 \mathrm{M}$, $1.08 \mathrm{mmol}$ ) were added. The solution was degassed (vacuum / nitrogen cycles $\mathrm{x} 5$ ), $\mathrm{Pd}\left[\mathrm{P}(\mathrm{tBu})_{3}\right]_{2}$ (18.4 mg, $0.036 \mathrm{mmol}$ ) was added and the mixture stirred at $60{ }^{\circ} \mathrm{C}$ overnight. The reaction was allowed to cool to RT and partitioned between ethyl acetate and brine. The aqueous layer was extracted with ethyl acetate $(3 \times 20 \mathrm{~mL})$ and the combined organics were dried over $\mathrm{Na}_{2} \mathrm{SO}_{4}$, filtered and concentrated in vacuo to give a dark purple gum. The resultant solid was purified by column chromatography ( $80 \mathrm{~g}, 35 \%$ ethyl acetate/petroleum ether) to give $\mathbf{9 0}$ as a slightly brown gum (181 mg, 70\%). ${ }^{1} \mathrm{H}$ NMR (DMSO- $\left.d_{6}, 400 \mathrm{MHz}\right) \delta 8.45$ (d, $\left.J=4.8 \mathrm{~Hz}, 1 \mathrm{H}\right), 7.54-7.24$ (m, $20 \mathrm{H}), 6.62-6.58(\mathrm{~m}, 1 \mathrm{H}), 3.79-3.72(\mathrm{~m}, 4 \mathrm{H}), 3.20-3.14(\mathrm{~m}, 4 \mathrm{H}), 1.90-1.79(\mathrm{~m}, 2 \mathrm{H}), 1.34(\mathrm{~s}$, 9H). LRMS found for $\mathrm{M}^{+}+1,719.4, \mathrm{C}_{43} \mathrm{H}_{42} \mathrm{~F}_{3} \mathrm{~N}_{4} \mathrm{O}_{3}$ requires 719.32.

Step 5.90 (150 mg, $0.209 \mathrm{mmol})$ was dissolved in dry DCM (2 mL) and cooled in an ice-bath. Triethylsilane ( $97 \mathrm{mg}, 0.835 \mathrm{mmol}$ ) was added followed dropwise by TFA ( $2 \mathrm{~mL}$ ). The resulting mixture was stirred at $0{ }^{\circ} \mathrm{C}$ for $4 \mathrm{~h}$. The reaction mixture was concentrated in vacuo to give a cream solid/gum. This material was redissolved in ether/1 $\mathrm{M} \mathrm{HCl}$ and the organic layer was washed with $1 \mathrm{M} \mathrm{HCl}(3 \times 10 \mathrm{~mL})$. The combined aqueous layer was basified with saturated $\mathrm{NaHCO}_{3}$ and extracted with ethyl acetate $(4 \times 20 \mathrm{~mL})$. The combined ethyl acetate extracts were dried over $\mathrm{Na}_{2} \mathrm{SO}_{4}$, filtered and concentrated in vacuo to give a colourless gum. Purification by column chromatography ( $75 \mathrm{~g}, 9 \% \mathrm{MeOH}$ containing $1 \% \mathrm{NH}_{4} \mathrm{OH}$ in DCM) gave 20 (52 mg, $66 \%)$ as a white powder after lyophilization of the product from water/acetonitrile. ${ }^{1} \mathrm{H}$ NMR (400 MHz, DMSO- $\left.d_{6}\right) \delta 8.69(\mathrm{~d}, 1 \mathrm{H}, \mathrm{J}=4.5 \mathrm{~Hz}), 7.49$ - $7.52(\mathrm{~m}, 2 \mathrm{H}), 7.38(\mathrm{~s}, 1 \mathrm{H}), 7.27$ - $7.31(\mathrm{~m}$, 2H), $3.66-3.69(\mathrm{~m}, 2 \mathrm{H}), 3.40(2 \mathrm{H}, \mathrm{t}, \mathrm{J}=9.1 \mathrm{~Hz}), 2.70(\mathrm{~s}, 2 \mathrm{H}), 2.03-2.07(\mathrm{~m}, 2 \mathrm{H}), 1.79-1.84$ $(\mathrm{m}, 2 \mathrm{H}) .{ }^{19} \mathrm{~F}$ NMR $\left(376 \mathrm{MHz}, \mathrm{DMSO}-d_{6}\right) \delta-58.0$. HRMS found for $\mathrm{M}^{+}+1,377.1581$, $\mathrm{C}_{19} \mathrm{H}_{20} \mathrm{~F}_{3} \mathrm{~N}_{4} \mathrm{O}$ requires 377.1584 .

(3-(3-Methyl-5-(3-(trifluoromethyl)-1H-pyrazolo[3,4-b]pyridin-4-yl)phenyl)oxetan-3yl)methanamine trifluoroacetate (21). Step 1. To a solution of $[\mathrm{Rh}(\mathrm{COD}) \mathrm{Cl}]_{2}(103 \mathrm{mg}, 0.211$ $\mathrm{mmol})$ in dioxane $(30 \mathrm{~mL})$ was added aq. $\mathrm{KOH}(1.5 \mathrm{M}, 5.49 \mathrm{mmol})$ followed by ethyl 2-(oxetan3 -ylidene)acetate $(600 \mathrm{mg}, 4.22 \mathrm{mmol})$ and a solution of (3-bromo-5-methyl-phenyl)boronic acid $(1.36 \mathrm{~g}, 6.33 \mathrm{mmol})$ in dioxane $(10 \mathrm{~mL})$. After $30 \mathrm{~min}$, a further portion of boronic acid $(453 \mathrm{mg}$, $2.11 \mathrm{mmol}$ ) was added and the mixture stirred overnight at room temperature. Brine and ethyl acetate were added, the layers separated and the organics were washed with brine, dried $\left(\mathrm{MgSO}_{4}\right)$, filtered and concentrated. Purification by column chromatography $(15 \%$ ethyl acetate/hexanes) gave $92(474 \mathrm{mg}, 36 \%)$ as an orange oil. ${ }^{1} \mathrm{H}$ NMR $\left(400 \mathrm{MHz}, \mathrm{CDCl}_{3}\right) \delta 7.26$ $7.21(\mathrm{~m}, 1 \mathrm{H}), 7.11(\mathrm{~d}, J=0.7 \mathrm{~Hz}, 1 \mathrm{H}), 6.91(\mathrm{dd}, J=1.6,0.9 \mathrm{~Hz}, 1 \mathrm{H}), 4.98(\mathrm{~d}, J=6.1 \mathrm{~Hz}, 2 \mathrm{H})$, $4.85(\mathrm{~d}, J=6.1 \mathrm{~Hz}, 2 \mathrm{H}), 4.05(\mathrm{q}, J=7.1 \mathrm{~Hz}, 2 \mathrm{H}), 3.11(\mathrm{~s}, 2 \mathrm{H}), 2.34$ (d, $J=0.8 \mathrm{~Hz}, 3 \mathrm{H}), 1.17$ (t, $J$ $=7.1 \mathrm{~Hz}, 3 \mathrm{H})$. LRMS found for $\mathrm{M}^{+}+1,314.9, \mathrm{C}_{14} \mathrm{H}_{18} \mathrm{BrO}_{3}$ requires 313.05.

Step 2. To a solution of $92(474 \mathrm{mg}, 1.51 \mathrm{mmol})$ in $\mathrm{MeOH}(8 \mathrm{~mL})$ at $0{ }^{\circ} \mathrm{C}$ was added aq. $\mathrm{NaOH}$ $(1 \mathrm{M}, 3.03 \mathrm{mmol})$ and the reaction was allowed to warm to room temperature. After stirring for $16 \mathrm{~h}$, the reaction was concentrated and neutralized with $1 \mathrm{M} \mathrm{HCl}(3 \mathrm{~mL})$ and then extracted with ethyl acetate $(3 \times 20 \mathrm{~mL})$. The organics were washed with brine, dried $\left(\mathrm{MgSO}_{4}\right)$, filtered and concentrated to give $97(360 \mathrm{mg}, 83 \%)$ as a pale orange solid. ${ }^{1} \mathrm{H}$ NMR $\left(400 \mathrm{MHz}, \mathrm{MeOH}-d_{4}\right) \delta$ $7.27(\mathrm{dq}, J=1.7,0.9 \mathrm{~Hz}, 1 \mathrm{H}), 7.25(\mathrm{t}, J=1.9 \mathrm{~Hz}, 1 \mathrm{H}), 7.08(\mathrm{td}, J=1.6,0.8 \mathrm{~Hz}, 1 \mathrm{H}), 4.94(\mathrm{~d}, J=$ $6.2 \mathrm{~Hz}, 2 \mathrm{H}), 4.89(\mathrm{~d}, J=6.2 \mathrm{~Hz}, 2 \mathrm{H}), 3.13(\mathrm{~s}, 2 \mathrm{H}), 2.35(\mathrm{~d}, J=0.7 \mathrm{~Hz}, 3 \mathrm{H})$. LRMS found for $\mathrm{M}^{+}$ $+1,284.8, \mathrm{C}_{12} \mathrm{H}_{14} \mathrm{BrO}_{2}$ requires 285.00. 
Step 3. To a solution of 97 (360 $\mathrm{mg}, 1.26 \mathrm{mmol})$ in t-butanol $(5 \mathrm{~mL})$ was added triethylamine (141 mg, $1.39 \mathrm{mmol}$ ) followed by (azido(phenoxy)phosphoryl)oxybenzene (382 mg, $1.39 \mathrm{mmol}$ ) and the reaction heated to $80{ }^{\circ} \mathrm{C}$ for $4 \mathrm{~h}$. The mixture was allowed to cool and ethyl acetate and water were added. The organics were separated, dried $\left(\mathrm{MgSO}_{4}\right)$, filtered and concentrated to give a yellow oil. Purification by column chromatography (25\%-40\% ethyl acetate/hexanes) gave 98 (65 mg, 14\%) as a white solid. ${ }^{1} \mathrm{H}$ NMR $\left(400 \mathrm{MHz}, \mathrm{CDCl}_{3}\right) \delta 7.28-7.25(\mathrm{~m}, 1 \mathrm{H}), 6.98(\mathrm{~d}, J=$ $11.6 \mathrm{~Hz}, 1 \mathrm{H}), 6.77(\mathrm{~d}, J=13.4 \mathrm{~Hz}, 1 \mathrm{H}), 4.92(\mathrm{~d}, J=6.4 \mathrm{~Hz}, 2 \mathrm{H}), 4.73(\mathrm{~d}, J=6.4 \mathrm{~Hz}, 2 \mathrm{H}), 4.70$ $4.59(\mathrm{~m}, 1 \mathrm{H}), 3.67(\mathrm{~d}, J=6.4 \mathrm{~Hz}, 2 \mathrm{H}), 2.36(\mathrm{~s}, 3 \mathrm{H}), 1.44(\mathrm{~s}, 9 \mathrm{H})$. LRMS found for $\mathrm{M}^{+}+1$, $357.99, \mathrm{C}_{16} \mathrm{H}_{23} \mathrm{BrNO}_{3}$ requires 356.09 .

Step $4.98(65 \mathrm{mg}, 0.183 \mathrm{mmol})$ was dissolved in dioxane $(2 \mathrm{~mL})$ and bis(pinacolato)diboron (70 $\mathrm{mg}, 0.274 \mathrm{mmol})$ was added followed by potassium acetate $(53.7 \mathrm{mg}, 0.548 \mathrm{mmol})$ under nitrogen. $\mathrm{Pd}(\mathrm{dppf}) \mathrm{Cl}_{2}$.DCM $(7.5 \mathrm{mg}, 9.13 \mu \mathrm{mol})$ was added and the reaction mixture heated at 90 ${ }^{\circ} \mathrm{C}$ for $5 \mathrm{~h}$. The reaction mixture was cooled, diluted with ethyl acetate, washed with brine and then dried $\left(\mathrm{MgSO}_{4}\right)$, filtered and concentrated. Purification by column chromatography $(30 \%$ $40 \%$ ethyl acetate/hexanes) gave 99 (40 mg, 54\%) as a white solid. ${ }^{1} \mathrm{H}$ NMR (400 MHz, $\left.\mathrm{CDCl}_{3}\right) \delta$ $7.57(\mathrm{~d}, J=0.8 \mathrm{~Hz}, 1 \mathrm{H}), 7.27(\mathrm{~s}, 1 \mathrm{H}), 6.95(\mathrm{~s}, 1 \mathrm{H}), 4.99(\mathrm{~d}, J=5.9 \mathrm{~Hz}, 2 \mathrm{H}), 4.75(\mathrm{~d}, J=6.1 \mathrm{~Hz}$, 2H), $4.64(\mathrm{~s}, 1 \mathrm{H}), 3.69(\mathrm{~d}, J=6.3 \mathrm{~Hz}, 2 \mathrm{H}), 2.38(\mathrm{~d}, J=1.0 \mathrm{~Hz}, 3 \mathrm{H}), 1.44(\mathrm{~s}, 9 \mathrm{H}), 1.37(\mathrm{~s}, 12 \mathrm{H})$. LRMS found for $\mathrm{M}^{+}+1,404.2, \mathrm{C}_{22} \mathrm{H}_{35} \mathrm{BNO}_{5}$ requires 404.26 .

Step 5. In a microwave vial were placed 99 (40 mg, $0.0992 \mathrm{mmol}), 37$ (55 mg, $0.0992 \mathrm{mmol}$ ), aq. $\mathrm{Na}_{2} \mathrm{CO}_{3}(2 \mathrm{M}, 0.330 \mathrm{mmol})$ and dioxane $(1.2 \mathrm{~mL}) . \mathrm{Pd}\left(\mathrm{PPh}_{3}\right)_{4}(5.7 \mathrm{mg}, 4.96 \mu \mathrm{mol})$ was added, the vial capped and the reaction heated in the microwave for $30 \mathrm{~min}$ at $150{ }^{\circ} \mathrm{C}$. Water and ethyl acetate were added, the aqueous layer re-extracted twice with ethyl acetate and the combined organics washed with brine, dried $\left(\mathrm{MgSO}_{4}\right)$, filtered and concentrated. Purification by column chromatography (30\% ethyl acetate/hexanes) gave $\mathbf{1 0 0}(34 \mathrm{mg}, 49 \%)$ as a white solid. ${ }^{1} \mathrm{H}$ NMR $\left(400 \mathrm{MHz}, \mathrm{DMSO}-d_{6}\right) \delta 8.38(\mathrm{~d}, J=4.6 \mathrm{~Hz}, 1 \mathrm{H}), 7.38-7.16(\mathrm{~m}, 17 \mathrm{H}), 7.09(\mathrm{~s}, 1 \mathrm{H}), 7.02(\mathrm{~s}, 1 \mathrm{H})$, $4.76(\mathrm{~d}, J=6.2 \mathrm{~Hz}, 2 \mathrm{H}), 4.72(\mathrm{~d}, J=6.2 \mathrm{~Hz}, 1 \mathrm{H}), 4.70-4.64(\mathrm{~m}, 1 \mathrm{H}), 3.37$ (app s, 2H), 2.37 (s, $3 \mathrm{H}), 1.30(\mathrm{~s}, 9 \mathrm{H})$. LRMS found for $\mathrm{M}^{+}+1,704.8, \mathrm{C}_{42} \mathrm{H}_{40} \mathrm{~F}_{3} \mathrm{~N}_{4} \mathrm{O}_{3}$ requires 705.31 .

Step 6. To a solution of $\mathbf{1 0 0}(34 \mathrm{mg}, 0.0482 \mathrm{mmol})$ in DCM $(2 \mathrm{~mL})$ at $0{ }^{\circ} \mathrm{C}$ was added triethylsilane $(22.4 \mathrm{mg}, 0.193 \mathrm{mmol})$ and TFA $(0.3 \mathrm{~mL})$ and the solution stirred at $0{ }^{\circ} \mathrm{C}$ for $1 \mathrm{~h}$. The solvent was removed under reduced pressure. After purification by prep HPLC the relevant fractions were freeze-dried to give $21(4.8 \mathrm{mg}, 21 \%)$ as a white solid. ${ }^{1} \mathrm{H}$ NMR $(400 \mathrm{MHz}$, DMSO- $\left.d_{6}\right) \delta 14.81($ br s, $1 \mathrm{H}), 8.73(\mathrm{~d}, 1 \mathrm{H}, \mathrm{J}=4.6 \mathrm{~Hz}), 7.92(3 \mathrm{H}, \mathrm{br} \mathrm{s}), 7.30(\mathrm{~d}, 1 \mathrm{H}, \mathrm{J}=4.6 \mathrm{~Hz})$, $7.28(\mathrm{~s}, 1 \mathrm{H}), 7.20(\mathrm{~s}, 1 \mathrm{H}), 7.15(\mathrm{~s}, 1 \mathrm{H}), 4.87(\mathrm{~d}, 2 \mathrm{H}, \mathrm{J}=6.6 \mathrm{~Hz}), 4.76(\mathrm{~d}, 2 \mathrm{H}, \mathrm{J}=6.6 \mathrm{~Hz}), 3.45(\mathrm{~s}$, $2 \mathrm{H}), 2.41(\mathrm{~s}, 3 \mathrm{H}) .{ }^{19} \mathrm{~F}$ NMR $\left(376 \mathrm{MHz}, \mathrm{DMSO}-d_{6}\right) \delta-57.7,-73.5$. HRMS found for $\mathrm{M}^{+}+1$, $363.1426, \mathrm{C}_{18} \mathrm{H}_{18} \mathrm{~F}_{3} \mathrm{~N}_{4} \mathrm{O}$ requires 363.1427 .

(3-(3-(3-(Trifluoromethyl)-1H-pyrazolo[3,4-b]pyridin-4-yl)phenyl)oxetan-3-yl)methanamine (22). Step 1. To a solution of $[\mathrm{Rh}(\mathrm{cod}) \mathrm{Cl}]_{2}(1.35 \mathrm{~g}, 2.77 \mathrm{mmol})$ in dioxane $(300 \mathrm{~mL})$ was added aq. $\mathrm{KOH}(1.5 \mathrm{M}, 120 \mathrm{mmol})$ followed by ethyl 2-(oxetan-3-ylidene)acetate $(15.4 \mathrm{~g}, 92.2 \mathrm{mmol})$ in dioxane $(170 \mathrm{~mL})$ and (3-bromophenyl)boronic acid $(27.8 \mathrm{~g}, 138 \mathrm{mmol})$. The reaction was stirred for $20 \mathrm{~min}$ then a further portion of (3-bromophenyl)boronic acid (10 g, $49.9 \mathrm{mmol})$ was added and the mixture stirred for a further $25 \mathrm{~min}$. Brine and ethyl acetate were added and the organic layer collected and washed with brine, dried $\left(\mathrm{MgSO}_{4}\right)$, filtered and concentrated under reduced pressure. The crude product was purified by column chromatography (330 g, 0-30\% ethyl acetate/petroleum ether) and gave $91(19.9 \mathrm{~g}, 72 \%)$ as an orange oil. ${ }^{1} \mathrm{H}$ NMR (DMSO- $d_{6}$, $400 \mathrm{MHz}) \delta 7.47-7.44(\mathrm{~m}, 2 \mathrm{H}), 7.34-7.26(\mathrm{~m}, 2 \mathrm{H}), 4.80(\mathrm{~d}, 2 \mathrm{H}, \mathrm{J}=7.2 \mathrm{~Hz}), 4.75(\mathrm{~d}, 2 \mathrm{H}, \mathrm{J}=7.2$ $\mathrm{Hz}), 3.92(2 \mathrm{H}, \mathrm{q}, \mathrm{J}=7.2 \mathrm{~Hz}), 3.15(\mathrm{~s}, 2 \mathrm{H}), 1.04(3 \mathrm{H}, \mathrm{t}, \mathrm{J}=7.2 \mathrm{~Hz})$. LRMS found for $\mathrm{M}^{+}+1$, 298.84, $\mathrm{C}_{13} \mathrm{H}_{16} \mathrm{BrO}_{3}$ requires 299.03 .

Step 2. 91 (19.9 g, $66.5 \mathrm{mmol})$ was dissolved in dioxane $(330 \mathrm{~mL})$ and bis(pinacolato)diboron (18.3 g, $72.0 \mathrm{mmol})$ was added followed by potassium acetate $(17.7 \mathrm{~g}, 180 \mathrm{mmol})$. The reaction 
mixture was degassed (vacuum/nitrogen cycling five times) then $\mathrm{Pd}(\mathrm{dppf}) \mathrm{Cl}_{2} . \mathrm{DCM}(2.45 \mathrm{~g}, 3.00$ mmol) was added and the mixture heated for $2 \mathrm{~h}$ at $90{ }^{\circ} \mathrm{C}$. After the mixture was allowed to cool, ethyl acetate was added and the mixture washed with brine, dried $\left(\mathrm{MgSO}_{4}\right)$, filtered and concentrated. Purification by column chromatography (300 g, 0-20\% ethyl acetate/petroleum ether) gave $93(18.7 \mathrm{~g}, 81 \%)$ as a dark orange oil. ${ }^{1} \mathrm{H}$ NMR $\left(400 \mathrm{MHz}, \mathrm{DMSO}-d_{6}\right) \delta 7.58-7.54$ $(\mathrm{m}, 1 \mathrm{H}), 7.50(\mathrm{q}, J=1.2 \mathrm{~Hz}, 1 \mathrm{H}), 7.44-7.33(\mathrm{~m}, 2 \mathrm{H}), 4.79(\mathrm{~s}, 4 \mathrm{H}), 3.90(\mathrm{q}, J=7.1 \mathrm{~Hz}, 2 \mathrm{H}), 3.13$ $(\mathrm{s}, 2 \mathrm{H}), 1.30(\mathrm{~s}, 12 \mathrm{H}), 1.03(\mathrm{t}, J=7.1 \mathrm{~Hz}, 3 \mathrm{H})$. LRMS found for $\mathrm{M}^{+}+1,347.1, \mathrm{C}_{19} \mathrm{H}_{28} \mathrm{BO}_{5}$ requires 347.21 .

Step 3. 93 (18.7 g, $54.0 \mathrm{mmol}$ ) and 4-iodo-3-(trifluoromethyl)-1-trityl-pyrazolo[5,4-b]pyridine $(25.0 \mathrm{~g}, 45.0 \mathrm{mmol})$ were dissolved in dry dioxane $(510 \mathrm{~mL})$ and $\mathrm{Na}_{2} \mathrm{CO}_{3}(2 \mathrm{M}, 135 \mathrm{mmol})$ was added. The solution was degassed (vacuum/nitrogen cycling five times), $\mathrm{Pd}\left[\mathrm{P}(\mathrm{tBu})_{3}\right]_{2}(1.15 \mathrm{~g}$, $2.25 \mathrm{mmol}$ ) was added, degassed again (vacuum/nitrogen cycling twice) and stirred at $60{ }^{\circ} \mathrm{C}$ for 3 $\mathrm{h}$. The reaction mixture was cooled to room temperature, diluted with ethyl acetate, washed with water, brine, dried $\left(\mathrm{MgSO}_{4}\right)$, filtered and concentrated under reduced pressure. Purification by column chromatography (330 g, 0-50\% ethyl acetate/petroleum ether) gave $94(20.0 \mathrm{~g}, 57 \%)$ as a tan foam. ${ }^{1} \mathrm{H}$ NMR (400 MHz, DMSO- $\left.d_{6}\right) \delta 8.40(\mathrm{~d}, J=4.6 \mathrm{~Hz}, 1 \mathrm{H}), 7.48(\mathrm{t}, J=7.9 \mathrm{~Hz}, 1 \mathrm{H})$, $7.44-7.11(\mathrm{~m}, 19 \mathrm{H}), 4.86(\mathrm{~d}, J=6.2 \mathrm{~Hz}, 2 \mathrm{H}), 4.78(\mathrm{~d}, J=6.2 \mathrm{~Hz}, 2 \mathrm{H}), 3.89(\mathrm{q}, J=7.1 \mathrm{~Hz}, 2 \mathrm{H})$, $3.16(\mathrm{~s}, 2 \mathrm{H}), 0.98(\mathrm{t}, J=7.1 \mathrm{~Hz}, 3 \mathrm{H}) .{ }^{19} \mathrm{~F}$ NMR (DMSO-d $\left.6,400 \mathrm{MHz}\right) \delta$-57.9. LRMS found for $\mathrm{M}^{+}+1,648.4, \mathrm{C}_{39} \mathrm{H}_{33} \mathrm{~F}_{3} \mathrm{~N}_{3} \mathrm{O}_{3}$ requires 648.25.

Step 4. 94 (46.1 g, $71.2 \mathrm{mmol})$ was dissolved in $\mathrm{MeOH}(400 \mathrm{~mL})$ and aq. $\mathrm{NaOH}(2 \mathrm{M}, 285 \mathrm{mmol})$ was added and the reaction stirred for $2.5 \mathrm{~h}$. At this stage, a further portion of aq. $\mathrm{NaOH}(2 \mathrm{M}, 100$ mmol) was added and the mixture stirred for $45 \mathrm{~min}$. The mixture was partially concentrated under reduced pressure to remove the majority of $\mathrm{MeOH}$ then re-dissolved in THF $(200 \mathrm{~mL})$, cooled in an ice bath and the mixture neutralized by careful addition of $2 \mathrm{M} \mathrm{HCl}$. After extraction with ethyl acetate twice, the combined organics were washed with brine, dried $\left(\mathrm{MgSO}_{4}\right)$, filtered and concentrated under reduced pressure to leave 95 (43 g, 97\%) as an orange foam. ${ }^{1} \mathrm{H}$ NMR $\left(400 \mathrm{MHz}, \mathrm{DMSO}-d_{6}\right) \delta 12.19(\mathrm{~s}, 1 \mathrm{H}), 8.40(\mathrm{~d}, J=4.6 \mathrm{~Hz}, 1 \mathrm{H}), 7.59-7.12(\mathrm{~m}, 20 \mathrm{H}), 4.84(\mathrm{~d}, J=$ $6.1 \mathrm{~Hz}, 2 \mathrm{H}), 4.78(\mathrm{~d}, J=6.1 \mathrm{~Hz}, 2 \mathrm{H}), 3.08(\mathrm{~s}, 2 \mathrm{H}) .{ }^{19} \mathrm{~F}$ NMR (DMSO- $\left.d_{6}, 400 \mathrm{MHz}\right) \delta-57.9$. LRMS found for $\mathrm{M}^{+}+1,620.4, \mathrm{C}_{38} \mathrm{H}_{29} \mathrm{~F}_{3} \mathrm{~N}_{3} \mathrm{O}_{3}$ requires 620.22 .

Step 5. To a solution of 95 (43 g, $69.4 \mathrm{mmol})$ and triethylamine $(7.37 \mathrm{~g}, 72.9 \mathrm{mmol})$ in dioxane $(500 \mathrm{~mL})$ was added diphenylphosphoryl azide $(20.1 \mathrm{~g}, 72.9 \mathrm{mmol})$ and the mixture heated at 85 ${ }^{\circ} \mathrm{C}$ for $1 \mathrm{~h}$. The mixture was then cooled to room temperature and then added dropwise to a rapidly stirring solution of lithium hydroxide $(4 \mathrm{M}, 1.82 \mathrm{mmol})$. Once addition was complete, stirring was continued for another $10 \mathrm{~min}$. The reaction was extracted with ethyl acetate twice and the combined organics washed with water, brine, dried $\left(\mathrm{MgSO}_{4}\right)$, filtered and concentrated under reduced pressure. Purification by column chromatography $(330 \mathrm{~g}, 0-5 \% \mathrm{MeOH}$ [containing $10 \%$ $\left.\mathrm{NH}_{4} \mathrm{OH}\right]$ in DCM) gave $96(37.2 \mathrm{~g}, 91 \%)$ as a cream foam. ${ }^{1} \mathrm{H}$ NMR $\left(400 \mathrm{MHz}, \mathrm{DMSO}-d_{6}\right) \delta$ $8.40(\mathrm{~d}, J=4.6 \mathrm{~Hz}, 1 \mathrm{H}), 7.51(\mathrm{t}, J=7.7 \mathrm{~Hz}, 1 \mathrm{H}), 7.43-7.08(\mathrm{~m}, 19 \mathrm{H}), 4.78(\mathrm{~d}, J=6.0 \mathrm{~Hz}, 2 \mathrm{H})$, $4.68(\mathrm{~d}, J=6.0 \mathrm{~Hz}, 2 \mathrm{H}), 3.09(\mathrm{~s}, 2 \mathrm{H}) .{ }^{19} \mathrm{~F}$ NMR (DMSO-d $\left.6,400 \mathrm{MHz}\right) \delta-57.8$. LRMS found for $\mathrm{M}^{+}+1,591.4, \mathrm{C}_{36} \mathrm{H}_{30} \mathrm{~F}_{3} \mathrm{~N}_{4} \mathrm{O}$ requires 591.24.

Step 6. 96 (37.2 g, $63.0 \mathrm{mmol})$ was dissolved in DCM (200 mL) and cooled in an ice bath. Triethylsilane (19.2 g, $165 \mathrm{mmol})$ was added followed by TFA $(62.7 \mathrm{~g}, 550 \mathrm{mmol})$. After $5 \mathrm{~min}$ the ice bath was removed and stirring continued for a further $20 \mathrm{~min}$. The reaction was poured into saturated aq. $\mathrm{NaHCO}_{3}(200 \mathrm{~mL})$ and extracted with ethyl acetate twice. The combined organics were washed with brine, dried $\left(\mathrm{MgSO}_{4}\right)$, filtered and concentrated. The residue was slurried in methanol and the trityl byproduct removed by filtration. Purification by column chromatography $\left(330 \mathrm{~g}, 0-7.5 \% \mathrm{MeOH}\right.$ [containing $10 \% \mathrm{NH}_{4} \mathrm{OH}$ ] in $\left.\mathrm{DCM}\right)$ gave product as a cream foam. This material was slurried in a small amount of MeCN and $22(8.22 \mathrm{~g}, 38 \%)$ was collected by filtration as a white solid. ${ }^{1} \mathrm{H}$ NMR $\left(400 \mathrm{MHz}\right.$ DMSO- $\left.d_{6}\right) \delta 8.70(\mathrm{~d}, J=4.6 \mathrm{~Hz}, 1 \mathrm{H})$, $7.50(\mathrm{~d}, J=7.7 \mathrm{~Hz}, 1 \mathrm{H}), 7.35(\mathrm{~d}, J=7.7 \mathrm{~Hz}, 1 \mathrm{H}), 7.30$ (d, $J=4.6 \mathrm{~Hz}, 1 \mathrm{H}), 7.24$ (d, $J=7.8 \mathrm{~Hz}$, 
1H), $7.18(\mathrm{~s}, 1 \mathrm{H}), 4.77(\mathrm{~d}, J=5.8 \mathrm{~Hz}, 2 \mathrm{H}), 4.66(\mathrm{~d}, J=5.8 \mathrm{~Hz}, 2 \mathrm{H}), 3.02(\mathrm{~s}, 2 \mathrm{H}) .{ }^{19} \mathrm{~F}$ NMR $(400$ $\mathrm{MHz}, \mathrm{DMSO}-\mathrm{d}_{6}$ ) $\delta-57.8$. Mass spectrum (ESI) $\mathrm{m} / z$ 349.1 [M $\left.+\mathrm{H}\right]^{+}$. HRMS found for $\mathrm{M}^{+}+1$, 349.1270, $\mathrm{C}_{17} \mathrm{H}_{16} \mathrm{~F}_{3} \mathrm{~N}_{4} \mathrm{O}$ requires 349.1271. 


\section{Description of Biochemical Assays}

\section{3a. PKC Inhibition Assays}

Compounds were screened for their ability to inhibit $\mathrm{PKC} \theta$ in a radioactive-phosphate incorporation assay using full-length recombinant $\mathrm{PKC} \theta$ enzyme. Assays were carried out in a 96-well plate containing $100 \mathrm{mM}$ HEPES (pH 7.5), $10 \mathrm{mM} \mathrm{MgCl}_{2}, 25 \mathrm{mM} \mathrm{NaCl}, 0.1 \mathrm{mM}$

EDTA, 0.01\% Brij, 2 mM DTT, 0.002\% Triton X-100, $200 \mu \mathrm{g} / \mathrm{mL}$ phosphatidylserine, $20 \mu \mathrm{g} / \mathrm{mL}$ diacylglycerol, $150 \mu \mathrm{M}$ substrate peptide (ERMRPRKRQGSVRRRV), $0.5 \mathrm{nM}$ PKC $\theta$ (Invitrogen, Madison, WI), and $240 \mu \mathrm{M}$ ATP $\left(\right.$ ATP $\left.\mathrm{K}_{\mathrm{m}}=40 \mu \mathrm{M}\right)$ in a final volume of $100 \mu \mathrm{L}$. Assays were performed at $25^{\circ} \mathrm{C}$ in the presence of $23 \mathrm{nCi} / \mu \mathrm{L}\left[\gamma_{-}{ }^{33} \mathrm{P}\right] \mathrm{ATP}$ (Perkin-Elmer, Beconsfield, U.K.). Serial dilutions of inhibitors were prepared in DMSO, and the reaction was initiated by the addition of ATP. The reaction was stopped after $60 \mathrm{~min}$ by the addition of $100 \mu \mathrm{L}$ of $100 \mathrm{mM}$ phosphoric acid, and a phosphocellulose 96-well plate (Millipore, catalog no. MAPHNOB) was washed with $200 \mu \mathrm{L}$ of $100 \mathrm{mM}$ phosphoric acid prior to the addition of the stopped reaction mixture $(120 \mu \mathrm{L})$. The plate was left to soak for at least $30 \mathrm{~min}$ prior to washing $(4 \times 200 \mu \mathrm{L}$ of $100 \mathrm{mM}$ phosphoric acid). After it was dried, $100 \mu \mathrm{L}$ of Optiphase "SuperMix" liquid scintillation cocktail (Perkin-Elmer) was added to the well. Initial rate data were determined from the level of ${ }^{33} \mathrm{P}$ incorporation measured using a 1450 MicroBeta liquid scintillation counter, Wallac. Compounds were screened for their ability to inhibit PKC $\delta$ or PKC $\alpha$ in a spectrophotometric assay using full-length, recombinant enzyme. Assays were carried out in a 384-well plate containing $100 \mathrm{mM}$ HEPES (pH 7.5), $10 \mathrm{mM} \mathrm{MgCl} 2,25 \mathrm{mM} \mathrm{NaCl}, 0.1 \mathrm{mM}$ EDTA, $0.01 \%$ Brij, $100 \mu \mathrm{M} \mathrm{CaCl}_{2}$ (PKC $\alpha$ only), $2 \mathrm{mM}$ DTT, $0.002 \%$ Triton X-100, $200 \mu \mathrm{g} / \mathrm{mL}$ phosphatidylserine (100 $\mu \mathrm{g} / \mathrm{mL}$ for $\mathrm{PKC} \alpha), 20 \mu \mathrm{g} / \mathrm{mL}$ diacylglycerol, $150 \mu \mathrm{M}$ substrate peptide (ERMRPRKR- QGSVRRRV(PKC $\delta$ ); RRRRRKGSFKRKA(PKC $\alpha$ )), $360 \mu \mathrm{M}$ NADH, $3 \mathrm{mM}$ phosphoenolpyruvate, $70 \mu \mathrm{g} / \mathrm{mL}$ pyruvate kinase, $24 \mu \mathrm{g} / \mathrm{mL}$ lactate dehydrogenase with $46 \mathrm{nM}$ PKC $\delta$ or $4.5 \mathrm{nM} \mathrm{PKC} \alpha$, and $150 \mu \mathrm{MATP}\left(\mathrm{K}_{\mathrm{m}}=50 \mu \mathrm{M}\right)$ or $130 \mu \mathrm{MATP}\left(\mathrm{K}_{\mathrm{m}}=45 \mu \mathrm{M}\right)$, respectively, in a final volume of $33 \mu \mathrm{L}$. Serial dilutions of inhibitors were prepared in DMSO, and the reaction was initiated by the addition of ATP. Initial rate data were determined from the rate of change of absorbance at $340 \mathrm{nM}$ (corresponding to stoichiometric consumption of NADH) using a Molecular Devices Spectramax plate reader (Sunnyvale, CA) over 15 min at $25^{\circ} \mathrm{C} . \mathrm{K}_{\mathrm{i}}$ values were calculated by fitting initial rate data to the model for competitive tight binding inhibition using the Prism software package (Prism 4.0a, Graphpad Software, San Diego, CA). 


\section{3b. Kinase Selectivity Assays}

Program compound were assayed against a small panel of kinases at Vertex for selectivity. The assays were performed at ATP Km in either a radiometric assay similar to that described above for the PKCs, or in a spectrophotometric assay. Assay platform and substrate for all included kinases are described in Table 2, and the buffer conditions are described in Table 3.

The radiometric assays for the tyrosine kinases use polyE4Y as a substrate. The radioactive assays using protein substrates also use this protocol. The kinases using peptide substrates require a change in the protocol. For these assays, the reaction was quenched with $25 \mathrm{~mL}$ of $5 \%$ phosphoric acid. The quenched reaction was transferred to phosphocellulose filter plates, allowed to bind for 1 hour, then washed 3 times with 1\% phosphoric acid. All other steps of the protocol are similar to the radioactive assay described for the PKCs.

In the spectrophotometric assay, the residual activity for each kinase was followed using spectrophotometric detection of a standard coupled-enzyme assay used for kinases. In this assay, each mole of ADP produced by the protein kinase-catalyzed reaction was coupled to the generation of one mole of NAD from NADH using pyruvate kinase (PK) and lactate dehydrogenase (LDH). The buffer conditions and final concentrations of the components in the coupled assay are described in Table 2. All Ki results were determined 8 times and included 6 individual compound lots.

Compound 22 was also profiled against a panel of 50 diverse kinases in the Eurofins Kinase Profiler Panel, Eurofins Discover Services, Dundee, Scotland. All assays were run at Km. Data are listed in Table 3. 
Table 1. ATP and Peptide Substrate Concentrations Used in Vertex Kinase Assays

\begin{tabular}{|c|c|c|c|c|}
\hline Kinase & $\begin{array}{c}\text { [AT } \\
\text { P] } \\
\boldsymbol{\mu M}\end{array}$ & [peptide] & Peptide & Assay Format \\
\hline CDK2/CycA & 80 & $150 \mu \mathrm{M}$ & MAHHHRSPRKRAKKK & Spectrophotometric \\
\hline DNAPK & 100 & $0.8 \mathrm{mg} / \mathrm{mL}$ & EPPLSQEAFADLWKKK & $\begin{array}{c}\text { Radiometric }- \\
\text { peptide }\end{array}$ \\
\hline FLT3 & 90 & $0.5 \mathrm{mg} / \mathrm{mL}$ & polyE4Y & Radiometric \\
\hline GSK3b & 10 & $0.55 \mathrm{mg} / \mathrm{mL}$ & HSSPHQS(PO3H2)EDEEE & Spectrophotometric \\
\hline IRAK4 & 800 & $1.4 \mathrm{mg} / \mathrm{mL}$ & SAMS peptide & Spectrophotometric \\
& & & polyE4Y & Radiometric \\
\hline JAK2 & 10 & $0.5 \mathrm{mg} / \mathrm{mL}$ & VSP1 & Spectrophotometric \\
\hline JNK3 & 40 & $1.3 \mathrm{mg} / \mathrm{mL}$ & polyE4Y & Spectrophotometric \\
\hline KDR & 100 & $0.5 \mathrm{mg} / \mathrm{mL}$ & polyE4Y & Radiometric \\
\hline MET & 450 & $0.5 \mathrm{mg} / \mathrm{mL}$ & Kemptide (LRRASLG) & Spectrophotometric \\
\hline PKA & 10 & $0.2 \mathrm{mg} / \mathrm{mL}$ & SAM68 & Radiometric \\
\hline PLK & 20 & $0.75 \mathrm{mg} / \mathrm{mL}$ & Myelin Basic Protein & Radiometric \\
\hline ROCK & 13 & $0.5 \mathrm{mg} / \mathrm{mL}$ & polyE4Y & Spectrophotometric \\
\hline SRC & 50 & $0.5 \mathrm{mg} / \mathrm{mL}$ & polyE4Y & Spectrophotometric \\
\hline SYK & 50 & $0.5 \mathrm{mg} / \mathrm{mL}$ & & \\
\hline & & & & \\
\hline
\end{tabular}

Table 2. Buffer Conditions Used in Vertex Kinase Assays

\begin{tabular}{|c|c|}
\hline Kinase & Buffer Conditions \\
\hline DNAPK & $\begin{array}{c}50 \mathrm{mM} \text { Hepes, } \mathrm{pH} \text { 7.4, } 10 \mathrm{mM} \mathrm{MgCl}_{2}, 1 \mathrm{mM} \mathrm{MnCl} \\
25 \mathrm{mM} \mathrm{NaCl}, 1 \mathrm{mM} \text { DTT, } 0.01 \% \text { BSA }\end{array}$ \\
\hline All polyE4Y & $\begin{array}{l}100 \mathrm{mM} \text { Hepes, pH 7.5, } 10 \mathrm{mM} \mathrm{MgCl} \mathrm{Mg}_{2} \\
25 \mathrm{mM} \mathrm{NaCl}, 1 \mathrm{mM} \text { DTT, } 0.01 \% \text { BSA }\end{array}$ \\
\hline $\begin{array}{c}\text { All } \\
\text { Spectrophotometric }\end{array}$ & $\begin{array}{c}100 \mathrm{mM} \text { HEPES, pH 7.5, } 10 \mathrm{mM} \mathrm{MgCl}_{2}, \\
1 \mathrm{mM} \text { DTT, } 2.5 \mathrm{mM} \text { phosphoenolpyruvate, } 200 \mu \mathrm{M} \mathrm{NADH}, 50 \mu \mathrm{g} / \mathrm{mL} \\
\text { pyruvate kinase, } 10 \mu \mathrm{g} / \mathrm{mL} \text { lactate dehydrogenase }\end{array}$ \\
\hline
\end{tabular}




\section{3c. Kinase profiling (larger panel):}

Table 3. Selectivity profile for compound 22 in Eurofins KinaseProfiler ${ }^{\mathrm{TM}}$ assays

\begin{tabular}{|c|c|c|c|c|c|}
\hline Enzyme & $\begin{array}{l}\text { \%Inhibition } \\
\text { (a) } 0.4 \mu \mathrm{M}\end{array}$ & $\begin{array}{c}\text { oInhibition } \\
\text { a } 2 \mu \mathrm{M}\end{array}$ & Enzyme & $\begin{array}{c}\text { \%Inhibition } \\
\text { @ } 0.4 \mu \mathrm{M}\end{array}$ & $\begin{array}{c}\text { \%Inhibition } \\
\text { (a) } 2 \mu \mathrm{M}\end{array}$ \\
\hline $\mathrm{ABL}$ & 0 & \begin{tabular}{|l|}
0 \\
\end{tabular} & MKK7 & 0 & $\begin{array}{l}0 \\
\end{array}$ \\
\hline ALK & 0 & 0 & MSK1 & 73 & 89 \\
\hline AMPKa1 & 2 & 32 & MST2 & 1 & 3 \\
\hline ASK1 & 0 & 3 & mTQR & 19 & 21 \\
\hline AXL & 0 & 0 & NEK2 & 0 & 3 \\
\hline BLK & 0 & 0 & P38b & 11 & 3 \\
\hline BTK & 0 & 1 & PAK2 & 0 & 0 \\
\hline CaMKIIb & 0 & 18 & PDGFR $\alpha$ & 0 & 0 \\
\hline CDK1/CycB & 4 & 43 & PKC $\beta 2$ & 8 & 16 \\
\hline CDK5/P35 & 0 & 50 & $\mathrm{PKCl}$ & 7 & 8 \\
\hline CHK1 & 0 & 9 & $\mathrm{PKC} \theta$ & 90 & 97 \\
\hline CK1 & 0 & 43 & PRAK & 0 & 0 \\
\hline EGFR & 0 & 0 & PRK2 & 0 & 77 \\
\hline EphB4 & 0 & 0 & RAFc & 1 & 9 \\
\hline ERK1 & 0 & 9 & RET & 0 & 0 \\
\hline FES & 48 & 73 & RIPK2 & 0 & 7 \\
\hline FGFR3 & 0 & 7 & ROCK II & 0 & 13 \\
\hline Flt1 & 12 & 60 & ROS & 1 & 14 \\
\hline FYN & 0 & 8 & RSK3 & 64 & 89 \\
\hline IGF1R & 0 & 0 & SGK & 4 & 19 \\
\hline IKK $\alpha$ & 2 & 5 & TIE2 & 0 & 0 \\
\hline IR & 1 & 14 & TrkA & 5 & 35 \\
\hline JNK1 & 0 & 0 & ZAP70 & 0 & 0 \\
\hline LCK & 0 & 11 & & & \\
\hline LYN & 4 & 5 & & & \\
\hline MEK1 & 10 & 9 & & & \\
\hline MKK6 & 0 & 5 & & & \\
\hline
\end{tabular}




\section{Description of Cellular Assays}

\section{4a. PBMC T Cell IL-2 Assays.}

PBMCs were prepared from human blood, washed, and adjusted to a cell density of $5 \times$ 105 cells $/ \mathrm{mL}$ in complete medium, and an amount of $100 \mu \mathrm{L}$ was added to wells of $96-$ well Immunosorp plates (Nunc), containing immobilized anti-human CD3 $(1.5 \mu \mathrm{g} / \mathrm{mL}$, Serotec, U.K.), anti-human CD28 (1 $\mu \mathrm{g} / \mathrm{mL}, \mathrm{BD}, \mathrm{U} . \mathrm{K}$.$) , and serial dilutions of PKC \theta$ inhibitors or DMSO vehicle. The cell assay plates were incubated for $24 \mathrm{~h}$ in a humidified incubator in $5 \% \mathrm{CO}_{2}$ at $37^{\circ} \mathrm{C}$. Supernatants were collected and IL-2 levels determined using a bead-based FLISA assay (Applied Biosystems, U.K.). $\mathrm{IC}_{50}$ values were determined by nonlinear regression analysis in Prism (Graphpad Software Inc.).

\section{4b. HFL-1 Assay.}

HFL1 cells are plated at $1.25 \times 10^{4} / 150 \mathrm{ul} /$ well and left to adhere overnight. Compounds are serial diluted, $50 \mu \mathrm{l}$ added to cell plate and incubated for $48 \mathrm{~h}$. 3H-Thymidine is added to the wells and left to incorporate for approximately $5 \mathrm{~h}$. Cells are subsequently harvested and read on a beta counter.

\section{4c. Th17 assay.}

This assay measures the effect of test compounds on IL-17 production by Memory CD4+ human Th17 cells. Memory CD4+ T cells are purified from human PBMCs and resuspended at $5 \times 10 \mathrm{E} 5 / \mathrm{ml} .100 \mathrm{ul} / \mathrm{well}$ of Memory CD4+ T cells are added to 96 well plates containing pre-bound anti-CD3, soluble anti-CD28 and compound dilutions or vehicle control. Plates are incubated for $24 \mathrm{~h}$ at $37^{\circ} \mathrm{C}, 5 \% \mathrm{CO} 2$ and supernatants subsequently removed for analysis. IL-17 levels are determined either by ELISA or Bead based assay (Luminex). 


\section{Molecular Modeling}

The crystal structure of human PKC $\theta$ in complex with 3-(8-((dimethylamino)methyl)6,7,8,9- tetrahydropyrido[1,2-a]indol-10-yl)-4-(1-methyl-1H-indol-3-yl)-1H- pyrrole-2,5dione solved at a resolution of $2.32 \AA$ was downloaded from the Protein Data Bank (PDB code 2JED; Stark et al., unpublished study). This structure shows the C-terminus in close contact with the ligand. When this structure was overlaid with other kinase crystal structures, an unusual conformation of Phe664 was observed (this conformation is most likely induced by the ligand crystallized, and it is not usually observed among kinases structures). Therefore, this structure, in absence of the ligand, was energy minimized using the MMFF94x force field within MOE (version 2010.10, Chemical Computing Group, Montreal, Canada) and a conformation for Phe664 similar to other kinases was obtained and this new minimized structure was used for docking.

A protein model of $\mathrm{PKC} \delta$ was created using the homology modeling tool within MOE. In order to create this protein model, the sequence of PKC $\delta$ was retrieved from UNIPROT (UNIPROT code Q05655; The UniProt Consortium, 2011) and homology modeling was carried out using as template the minimized PKC $\theta$ crystal structure described above. Medium model refinements were applied during the protein model generation. The sequence identity percentage between human $\mathrm{PKC} \theta$ and human $\mathrm{PKC} \delta$ for the kinase domain is approximately $72 \%$.

Molecular docking was performed using "Extra Precision (XP) Glide" (Schrödinger, New York, U.S.; Friesner et al., 2006). The docking algorithm performs a conformational analysis of the ligand in the kinase active site. In particular, the XP scoring function considers hydrophobic packing and presence of hydrogen bonds in hydrophobic environments that are important features in predicting protein-ligand interactions in the active sites of kinases. 


\title{
6. In vivo Pharmacology
}

\author{
6a. EAE Study
}

All studies were performed in compliance with the regulations of the Institutional Animal Care and Use Committee. To induce EAE 6-8 weeks old female C57BL/6 mice were immunized via subcutaneous injection of $250 \mu \mathrm{g} \mathrm{MOG}_{35-55}$ peptide per mouse, in PBS and emulsified in equal volume of complete Freund's adjuvant containing Mycobacterium tuberculosis H37RA at a final concentration of $0.5 \mathrm{mg} / \mathrm{ml}$. Pertussis toxin (final concentration $200 \mathrm{ng}$ /mouse) was also administered via intraperitoneal injections on day of immunization and two days later. Mice were monitored daily and beginning on day 8 were monitored for disease onset and clinical score. Animals were dosed orally with compound when they had a clinical score of 1-1.5. Compound 22 was administered BID. Clinical signs of neurologic defect were scored on a 0 to 5 scale as follows: $0=$ Normal, $0.5=$ Tail tone weakness, $1=$ Limp tail, $1.5=$ Limp tail, difficulty righting, 2 = Partial hind limb paralysis, waddling gait, $2.5=$ Partial hind limb paralysis with one hind limb dragging, 3 = Complete hind limb paralysis, dragging lower body, 3.5 $=$ Complete hind limb paralysis, fore limb weakness, $4=$ Complete hind limb paralysis, partial fore limb paralysis, $4.5=$ Complete hind and fore limb paralysis, $5=$ Moribund, starting at day 8 of immunization.

The data were analysed with a one way ANOVA followed by a Tukey's multiple comparisons test. One star signifies $p<0.05$ and the two stars signify $P<0.01$ for the 50 and $100 \mathrm{mg} / \mathrm{kg}$ doses of $\mathbf{2 2}$ compared to the vehicle control. For all the statistics run, ${ }^{*}$ is $\mathrm{p}<0.05, * *$ is $\mathrm{p}<0.01, * * *$ is $\mathrm{p}<0.001$ and $* * * *$ is $\mathrm{P}<0.0001$. This test effectively compares all the treatment groups and vehicle control group with one another. The $p$ values relate to the data point and the spread of the data around that data point. Hence a $p$ value can become more significant (i.e. $p<0.01$ ) if the spread of the data is less (smaller error bars) and/or the average of the data being compared are further apart. In our study, it is the fact that the mean clinical scores are separating further as the study progresses for the 22- treated groups that is driving the change in the $p$ values. The $25 \mathrm{mg} / \mathrm{kg} \mathbf{2 2}$ treatment group was not statistically significant compared to the vehicle control at all time points. Both the 50 and $100 \mathrm{mg} / \mathrm{kg}$ treatment groups show significance compared to the vehicle control group. This began from Day 10 for the $50 \mathrm{mg} / \mathrm{kg}$ group and from Day 7 for the $100 \mathrm{mg} / \mathrm{kg}$ group and continued to the end of the study. We had to run relatively high $\mathrm{n}$ numbers for each of the study groups for this study to allow for statistical comparisons. Each of the data points are mean $+/$ - standard error of the mean. Study group sizes were $\mathrm{n}=10$ for the vehicle control, 25 and $50 \mathrm{mg} / \mathrm{kg} 22$-treated groups and $\mathrm{n}=12$ for the $100 \mathrm{mg} / \mathrm{kg}$ 22-treated group. The graphs were simplified to make everything less crowded by only using one error bar for each of the data points to allow space to put the stars on. 
Dexamethasone was dosed in a different study to the study depicted in Figure 5 of the manuscript and this is why it has been plotted separately here. The statistics that were used on the dexamethasone graph was an unpaired two-tailed t-test.

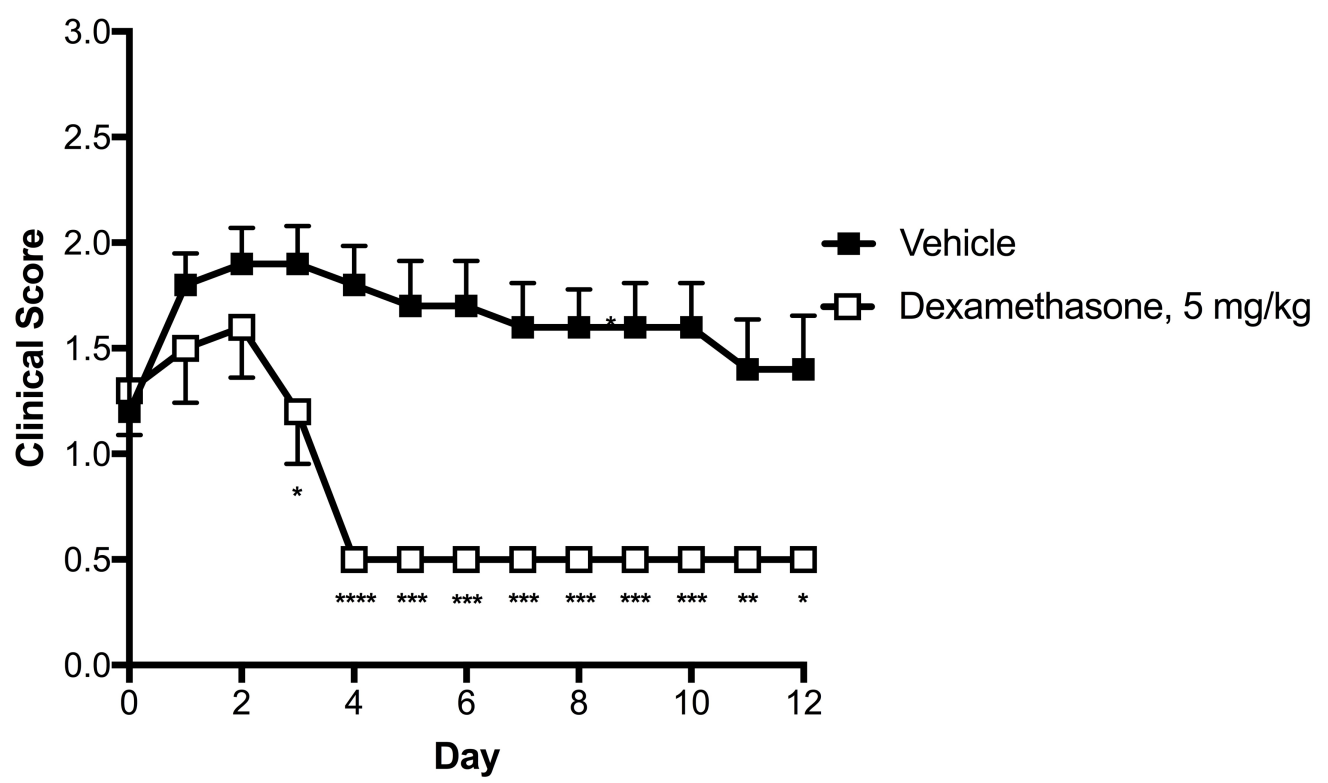

\section{6b. IL-2 study}

- Compound 22 significantly inhibits IL-2 production in vivo

- Female Balb/c mice (8 weeks; $\mathrm{n}=8$ animals/treatment group)

- Treatment Groups

○ Vehicle (20\% captisol in $50 \mathrm{mM}$ citrate buffer, $\mathrm{pH} 4.3$ )

○ Cyclosporin A $(15 \mathrm{mg} / \mathrm{kg})$

○ Compound $22(25,50,100 \mathrm{mg} / \mathrm{kg})$ 


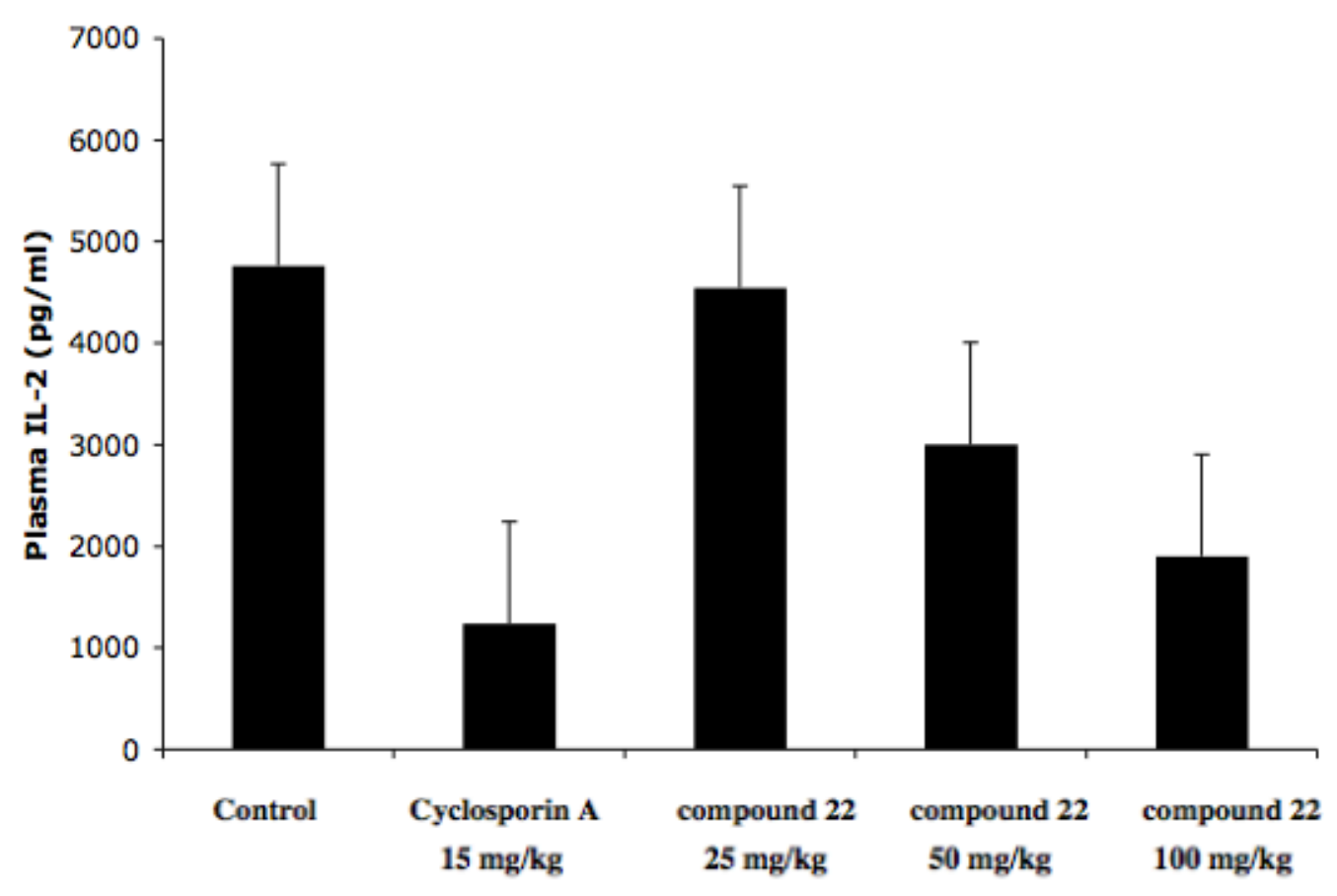

\begin{tabular}{|c|c|c|c|c|c|c|}
\hline Compound & $\begin{array}{c}\% \\
\text { Inhibition }\end{array}$ & $\begin{array}{c}\text { [plasma]* } \\
\text { ng/mL }\end{array}$ & $\begin{array}{c}\text { [brain]* } \\
\text { ng/mL }\end{array}$ & $\begin{array}{c}\text { [spleen] }{ }^{*} \\
\text { ng/mL }\end{array}$ & $\begin{array}{c}{\left[\text { plasma }_{\mathrm{u}}\right]^{*, \mathrm{a}}} \\
\mathrm{ng} / \mathrm{mL}\end{array}$ & $\begin{array}{c}{\left[\text { brain }_{\mathrm{u}}\right]^{*, \mathrm{~b}}} \\
\text { ng/mL }\end{array}$ \\
\hline Vehicle & - & - & - & - & & - \\
\hline $\begin{array}{c}\text { Cyclosporin } \\
\text { A } \\
15 \mathrm{mg} / \mathrm{kg} \\
\end{array}$ & 74 & ND & ND & ND & ND & ND \\
\hline $\begin{array}{l}\text { Compound } 22 \\
25 \mathrm{mg} / \mathrm{kg}\end{array}$ & 5 & 262 & 158 & 993 & 67 & 26 \\
\hline $\begin{array}{l}\text { Compound } 22 \\
50 \mathrm{mg} / \mathrm{kg}\end{array}$ & 37 & 971 & 446 & 3648 & 248 & 72 \\
\hline $\begin{array}{l}\text { Compound } 22 \\
100 \mathrm{mg} / \mathrm{kg}\end{array}$ & 60 & 2715 & 930 & 12383 & 692 & 151 \\
\hline
\end{tabular}

*concentrations measured at $3 \mathrm{~h}$ after po dose; ${ }^{\mathrm{a}}$ based on free fraction in mouse plasma of $25.5 \%$; ${ }^{\mathrm{b}}$ based on free fraction in mouse brain tissue of $16.2 \%$. 


\section{Physiochemical Properties and DMPK Assays}

\section{7a. Solubility}

The aim of the assay is to determine the thermodynamic solubility of VRT compounds at pH 7.40 in $50 \mathrm{mM}$ sodium phosphate buffer with $150 \mathrm{mM}$ sodium Chloride.

Reagent A. Preparation of 50mM sodium phosphate buffer with $150 \mathrm{mM}$ sodium chloride at $\mathrm{pH}$ 7.40

To $100 \mathrm{~mL}$ Deuterated water $\left(\mathrm{D}_{2} \mathrm{O}\right)$ add $890 \mathrm{mg} \mathrm{Na}_{2} \mathrm{HPO}_{4} .2 \mathrm{H}_{2} \mathrm{O}$ and $877 \mathrm{mg} \mathrm{NaCl}$. Dissolve completely then adjust $\mathrm{pH}$ to $7.50 \pm 0.02$ with $\mathrm{HCl}$ or $\mathrm{NaOH}$ as required. This reagent may be used for up to 1 month. $\mathrm{NB}_{2} \mathrm{O}$ disrupts the Hydrogen ion activity. Previous experimentation has shown that $\mathrm{pH} 7.5$ in $\mathrm{D}_{2} \mathrm{O}$ equates to $\mathrm{pH} 7.4$ in $\mathrm{H}_{2} \mathrm{O}$.

Experimental procedure.

- Add $1000 \mu \mathrm{L}$ of Reagent $A$ buffer to each vial.

- Mount on the rack of a Stuart mixer (balancing the number of vials on the carriage) and tumble for $24 \mathrm{~h}$ at $18-20 \mathrm{rpm}$.

- Following tumbling, allow to sediment (stand) for $48 \mathrm{~h}$

- Centrifuge the plate at in the Hettich Rotanta 460R at $2000 \mathrm{rpm}$ for 10 minutes at room temperature.

- Transfer $700 \mu \mathrm{L}$ of supernatant to a labelled NMR tube.

- Take all the tubes to the NMR Lab for analysis.

- Enter the concentrations in the worksheet and upload the data to ART.

Preparation of DMMA Calibration Check.

- Prepare a concentrated stock of DMMA at $40 \mathrm{mM}$ in $\mathrm{D}_{2} \mathrm{O}$-buffer.

- Accurately weigh out > $10 \mathrm{mg}$ DMMA. Add a calculated volume of $\mathrm{D}_{2} \mathrm{O}$-buffer to give concentration of $40 \mathrm{mM}$.

- To a fresh $2 \mathrm{~mL}$ Covaris vial add $700 \mu \mathrm{L}$ of $\mathrm{D}_{2} \mathrm{O}$-buffer followed by $100 \mu \mathrm{L}$ of the 40 $\mathrm{mM}$ stock DMMA to give a final concentration of $5 \mathrm{mM}$

- Transfer $700 \mu \mathrm{L}$ of the $5 \mathrm{mM}$ solution to an NMR tube and seal tightly.

\section{7b. Hepatocyte stability}

In vitro hepatocyte clearance data (rat/human) for compounds $\mathbf{5 - 1 1}\left(\mu \mathrm{L} / \mathrm{min} / 10^{6}\right.$ cells):
5: $\quad 6.7,4.2$
6: $24,6.4$
7: 19,17
8: ND, ND
9: $<1.8,<1.8$
10: $70,8.8$
11: $58,6.3$ 


\section{7c. Permeability assay}

\section{EA202 \\ Express Bidirectional Permeability Through Caco-2 Cell Monolayers}

This assay is used to determine the permeability of a test compound through Caco- 2 cell monolayers in the apical-to-basolateral and basolateralto-apical direction

\begin{tabular}{|c|c|}
\hline \multirow[t]{3}{*}{ Required from Customer } & $\begin{array}{l}\text { - Either a minimum of } 300 \mu \mathrm{L} \text { of test compound at } 10 \mathrm{mM} \text { in } \\
\text { DMSO, or } 5 \mathrm{mg} \text { of powder }\end{array}$ \\
\hline & $\begin{array}{l}\text { - Molecular mass (exact mass) of the test compound and its } \\
\text { salt form }\end{array}$ \\
\hline & $\begin{array}{l}\text { - MSDS or handling and storage information, e.g., light } \\
\text { sensitive, store at }-20^{\circ} \mathrm{C} \text {, etc. }\end{array}$ \\
\hline \multirow[t]{8}{*}{ Deliverables } & $\begin{array}{l}\text { - The percent recovery of the test compound from the } \\
\text { Transwell|s wells containing Caco-2 cell monolayers }\end{array}$ \\
\hline & - The apparent permeability $\left(P_{\text {app }}\right)$ in both directions \\
\hline & $\begin{array}{l}\text { - The absorption potential of a test compound classified as } \\
\text { either Low or High using the following criteria for the apical- } \\
\text { to-basolateral }(A \rightarrow B) \text { direction: }\end{array}$ \\
\hline & $\cdot$ Low: $P_{\text {app }}<1.0 \times 10^{-6} \mathrm{~cm} / \mathrm{s}$ \\
\hline & . High: $P_{\text {app }} \geq 1.0 \times 10^{-6} \mathrm{~cm} / \mathrm{s}$ \\
\hline & - The efflux ratio $\left(P_{a p p} B \rightarrow A\right) /\left(P_{a p p} A \rightarrow B\right)$ \\
\hline & - The efflux is classified as Significant when: \\
\hline & . efflux $\geq 3.0$ and $P_{a p p}(B \rightarrow A) \geq 1.0 \times 10^{-6} \mathrm{~cm} / \mathrm{s}$ \\
\hline Substrate & $\begin{array}{l}\text { - Test compound at } 5 \mu \mathrm{M} \text { in HBSSg with maximum DMSO } \\
\text { concentration less than } 1 \%\end{array}$ \\
\hline Assay System & - Confluent monolayers of Caco-2 cells, 21 to 28 days old \\
\hline \multirow[t]{7}{*}{ Assay Conditions } & - Receiver well with $1 \%$ BSA in modified Hanks buffer $\mathrm{HBSSg}$ \\
\hline & - Apical and basolateral side at pH $7.4 \pm 0.2$ \\
\hline & - Two monolayers dosed in each direction $(\mathrm{N}=2)$ \\
\hline & - Dose apical side for $(A \rightarrow B)$ assessment \\
\hline & - Dose basolateral side for $(B \rightarrow A)$ assessment \\
\hline & - Sample both apical and basolateral sides at 120 minutes \\
\hline & $\begin{array}{l}\text { Determine the concentrations of test compound using } \\
\text { a generic LC/MS/MS method with a minimum } 4 \text { point } \\
\text { calibration curve }\end{array}$ \\
\hline \multirow[t]{2}{*}{ Assay QC } & $\begin{array}{l}\text { - The quality of the monolayer batch is verified using control } \\
\text { compounds before the monolayers are released for use }\end{array}$ \\
\hline & $\begin{array}{l}\text { - The quality of each monolayer used in the assay is verified } \\
\text { by a TEER measurement and by calculating the } P_{\text {app }} \text { for a } \\
\text { control compound }\end{array}$ \\
\hline
\end{tabular}

ASSAY DATA SHEET

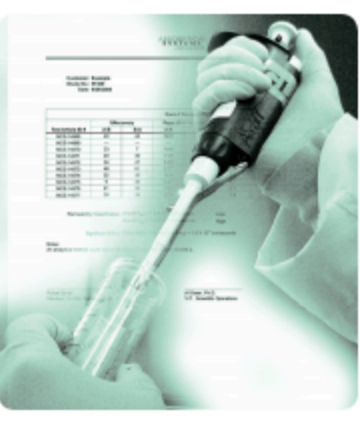

\section{References}

Sambuy Y, et al., The Caco-2 cell line as a model of the intestinal barrier: influence of cell and culture-related factors on Caco-2 cell functional characteristics. Cell Biol Toxicol. 2005 Jan;21(1):1-

Artursson P, et al., Caco-2 monolayers in experimental and theoretical predictions of drug transport. Adv Drug Deliv Rev. 2001 Mar 1; 46(1-3):27-43

\section{Absorption Systems designs and performs customer-initiated ADME studies. Please contact us to learn how we can assist you in understanding the ADME properties of your compound.}

Notes:

1. The results from this assay are sent to the customer in the basic report format

2. This assay broadly classifies the $P_{\text {app }}$ of a test compound-see EA212 for an alternative

3. For reproducible results the solubility of the test compound must be greater than $5 \mu \mathrm{M}$ in HBSSg with $1 \%$ DMSO

$\begin{array}{ll}\text { Absorption Systems, LP } & \text { Tel: } 610-280-7300 \\ 440 \text { Creamery Way, Suite 300 } & \text { Fax: } 610-280-9667 \\ \text { Exton, PA 19341-2554 USA } & \text { absorption.com }\end{array}$




\section{References}

1. Hodgson, P. B.; Salingue, F. H. The preparation of a stable 2-pyridylboronate and its reactivity in the Suzuki-Miyaura cross-coupling reaction. Tetrahedron Lett. 2004, 45, 685-687.

2. Rocca, P.; Cochennec, C.; Marsais, F.; Thomas-dit-Dumont, L.; Mallet, M.; Godard, A.; Quéguiner, G. First metalation of aryl iodides: directed ortho-lithiation of iodopyridines, halogen-dance, and application to synthesis. J. Org. Chem. 1993, 58, 7832-7838.

3. Wuitschik, G.; Rogers-Evans, M.; Müller, K.; Fischer, H.; Wagner, B.; Schuler, F.; Polonchuk, L.; Carreira, E. M. Oxetanes as promising modules in drug discovery. Angew. Chem. Int. Ed. Engl. 2006, 45, 7736-7739.

4. Hayashi, T.; Yamasaki, K. Rhodium-catalyzed asymmetric 1,4-addition and its related asymmetric reactions. Chem. Rev. 2003, 103, 2829-2844. 